\title{
AVALIAÇÃO DA QUALIDADE DAS VARIEDADES CHANDLER E REIKO PARA A OBTENÇÃO DE MORANGO EM CALDA
}

NEILA SILVIA PEREIRA DOS SANTOS RICHARDS

Engenheiro de Alimentos

Orientador: Prof. Dr. JOÃO NUNES NOGUEIRA

Dissertação apresentada à Escola Superior de Agricultura "Luiz de Queiroz", da Universidade de São Paulo, para obtenção do título de Mestre em Ciências, área de concentração - Ciência e Tecnologia de Alimentos. 
Dados Internacionais de Catalogação na Publicação (CIP)

DIVISÃO DE BIBLIOTECA E DOCUMENTAÇÃO - Campus "Luiz de Queiroz"/USP

Richards. Neila Silvia Pereira dos Santos

Avaliação da qualidade das variedades Chandler e Reiko para a obtenção de morango em calda / Neila Silvia Pereira dos Santos Richards. -- Piracicaba. 1996.

90 p.: II.

Dissertação (mestrado) -- Escola Superior de Agricultura Luiz de Queiroz. 1996

Bibliografia.

1. Morango - Tecnologia 2. Morango - Variedade - Qualidade 1. Título

CDD 664.80475 


\section{AVALIAÇÃO DA QUALIDADE DAS VARIEDADES CHANDLER E REIKO PARA A OBTENÇÃO DE MORANGO EM CALDA}

NEILA SILVIA PEREIRA DOS SANTOS RICHARDS

Aprovada em 29.11.96

Comissão julgadora:

Prof. Dr. João Nunes Nogueira

ESALQ/USP

Prof. Dr. Paulo Roberto Cantarelli

ESALQ/USP

Prof. Dr. Keigo Minami

ESALQ/USP

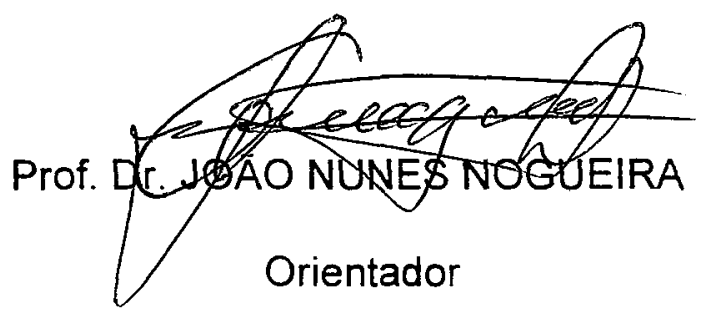


A Deus agradeço.

Ao Pablo pela compreensão, incentivo e profundo respeito para com minha carreira profissional, Ao David, com amor, Aos meus pais que sempre superaram as minhas expectativas, ofereço. 


\section{AGRADECIMENTOS}

- Ao meu orientador, Prof. Dr. João Nunes Nogueira, pela orientação, apoio e compreensão dedicada durante à elaboração deste trabalho.

- Aos professores do Curso de Mestrado, por seus ensinamentos.

- Aos Srs. Tatuo Sasiki e Oswaldo Sasiki, pela doação da matéria-prima necessária à realização deste trabalho.

- Ao Prof. Dr. David Ariovaldo Banzatto, do departamento de Ciências Exatas da FCAV - UNESP, pelo mirifico auxilio nas partes estatítica e gráfica deste trabalho.

- À Sra. Ivani Aparecida Marchetto Moreno, técnica do departamento de Ciência e Tecnologia Agroindustrial, pelo auxílio e apoio prestado na parte prática.

- Aos técnicos Luis Lucatti e José Carlos Teixeira Mendes, pelo apoio na realização da parte prática deste trabalho.

- À BASF - Divisão de Vitaminas e Corantes, pela doação de corantes artificiais.

- À Star e Arty, pela doação de corantes naturais.

- À Matarazzo, pela doação de latas.

- A Bibliotecária Beatriz Helena Giongo, pelo auxilio na revisão e correção das referências bibliográficas deste trabalho.

- À secretária da pós-graduação Regina Lúcia de Mello Lourenço, pelo apoio.

- Aos membros do painel sensorial, pela colaboração inestimável.

- À Fundação de Coordenação de Aperfeiçoamento de Pessoal de Nivel Superior - CAPES e a Fundação de Amparo à Pesquisa do Estado de São Paulo - FAPESP, pelo apoio financeiro a realização deste trabalho.

- Aos colegas e amigos, que sempre me incentivaram e de alguma maneira contribuiram para a execução deste trabalho. 


\section{ÍNDICE}

Página

LISTA DE FIGURAS

LISTA DE TABELAS

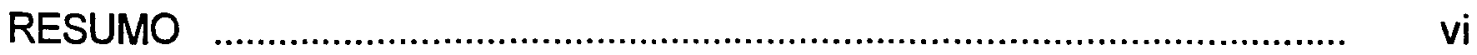

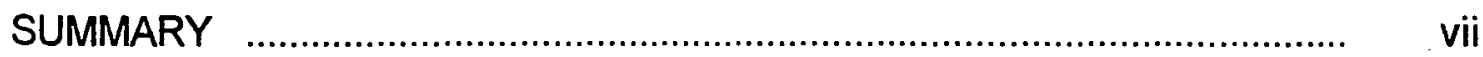

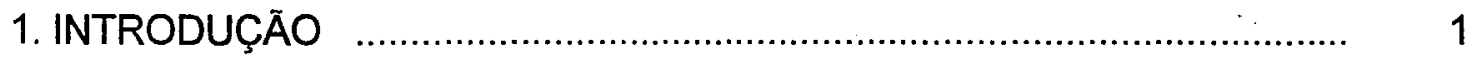

2. OBJETIVO E METAS

3. REVISÃO DE LITERATURA

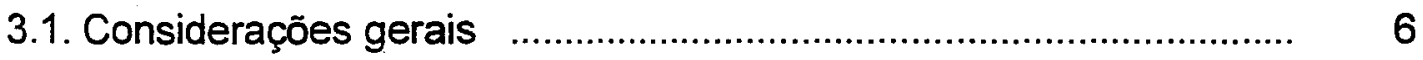

3.2. Variedades de morango

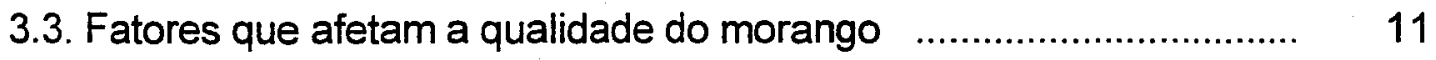

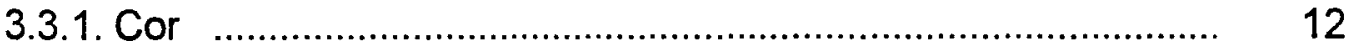

3.3.2. Textura

3.3.3. Ácido ascórbico

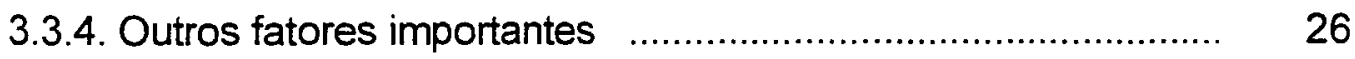

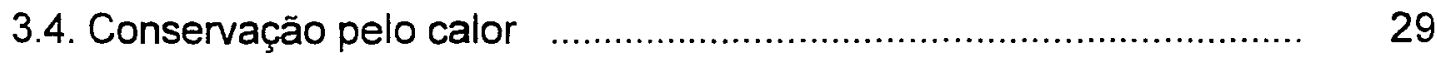

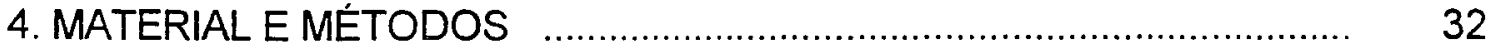

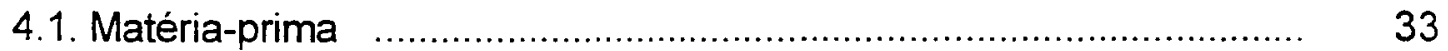


4.2. Caracterização da matéria-prima

4.2.1. Análises físicas .................................................................. 33

4.2.2. Análises químicas ….........................................................

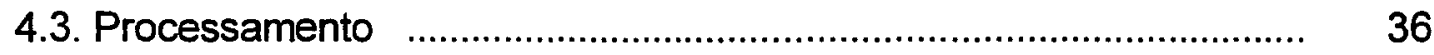

4.3.1. Tratamentos de pré-processamento ………………............. $\quad 36$

4.3.2. Acondicionamento

4.3.3. Exaustão e recravação …………………………………..... 41

4.3.4. Esterilização e resfriamento ………………………….......... 41

4.3.5. Armazenamento ............................................................... 41

4.4. Avaliação do produto processado

4.4.1. Análises fisicas $\quad$................................................................... 42

4.4.2. Análises químicas $\quad$.............................................................. 43

4.4.3. Análise sensorial

4.4.4. Análise estatistica dos resultados

5. RESULTADOS E DISCUSSÃO

5.1. Caracterização da matéria-prima

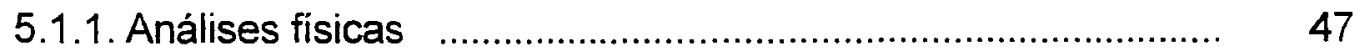

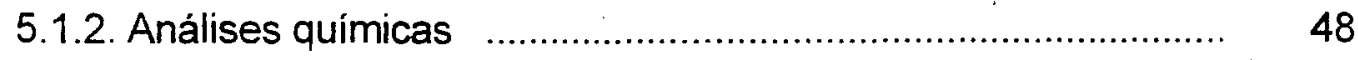

5.2. Caracterização do produto final …………...................................... 50 
Figura 12 - Variação do vácuo (pol. $\mathrm{Hg}$ ) de acordo com os períodos de armazenamento - Variedade Reiko

Figura 13 - Variação do pH (parte sólida: frutos) de acordo com os períodos de armazenamento - Variedade Chandler

Figura 14 - Variação do pH (parte sólida: frutos) de acordo com os períodos de armazenamento - Variedade Reiko

Figura 15 - Variação do pH (parte líquida: calda) de acordo com os periodos de armazenamento - Variedade Chandler

Figura 16 - Variação do pH (parte liquida: calda) de acordo com os períodos de armazenamento - Variedade Reiko

Figura 17 - Variação da acidez total titulável ( $\mathrm{g}$ de ácido citrico/100 g de amostra) de acordo com os períodos de armazenamento Variedade Chandler

Figura 18 - Variação da acidez total titulável ( $\mathrm{g}$ de ácido citrico/100 g de amostra) de acordo com os períodos de armazenamento Variedade Reiko

Figura 19 - Variação dos sólidos solúveis (parte sólida: frutos) de acordo com os períodos de armazenamento - Variedade Chandler

Figura 20 - Variação dos sólidos solúveis (parte sólida: frutos) de acordo com os periodos de armazenamento - Variedade Reiko

Figura 21 - Variação dos sólidos solúveis (parte líquida: calda) de acordo com os periodos de armazenamento - Variedade Chandler

Figura 22 - Variação dos sólidos solúveis (parte líquida: calda) de acordo com os periodos de armazenamento - Variedade Reiko 
Figura 23 - Variação dos teores de ácido ascórbico (mg/100 $\mathrm{g}$ de frutos) obtidos de acordo com os períodos de armazenamento Variedade Chandler

Figura 24 - Variação dos teores de ácido ascórbico (mg/100 $\mathrm{g}$ de frutos) obtidos de acordo com os períodos de armazenamento Variedade Reiko 72

Figura 25 - Valores médios obtidos na avaliação sensorial das amostras quanto ao atributo textura, segundo as variedades

Figura 26 - Valores médios obtidos na avaliação sensorial das amostras quanto ao atributo sabor, segundo as variedades

Figura 27 - Valores médios obtidos na avaliação sensorial das amostras quanto ao atributo cor, segundo as variedades 


\section{LISTA DE TABELAS}

Página

Tabela 1 - Características físicas das variedades de morango "in natura" (matéria - prima)

Tabela 2 - Características quimicas das variedades de morango "in natura" (matéria - prima)

Tabela 3 - Peso bruto $(\mathrm{g})$ dos morangos termicamente processados ....

Tabela 4 - Peso drenado dos morangos termicamente processados

Tabela 5 - Peso líquido dos morangos termicamente processados

Tabela 6 - Suculência ( $\mathrm{ml} \mathrm{suco/g}$ amostra) dos morangos termicamente processados

Tabela 7 - Textura (lbf/g de amostra) dos morangos termicamente processados

Tabela 8 - Vácuo (pol. $\mathrm{Hg}$ ) dos morangos termicamente processados ...

Tabela 9 - $\mathrm{pH}$ dos morangos termicamente processados - parte sólida (frutos)

Tabela 10 - pH dos morangos termicamente processados - parte liquida (calda)

Tabela 11 - Acidez total titulável ( $\mathrm{g}$ de ácido cítrico/100 g de amostra) dos morangos termicamente processados

Tabela 12 - Sólidos solúveis (Brix) dos morangos termicamente processados - parte sólida (frutos) 
Tabela 13 - Sólidos solúveis (Brix) dos morangos termicamente processados - parte liquida (calda)

Tabela 14 - Vitamina C (mg/100 g amostra) dos morangos termicamente processados

Tabela 15 - Avaliação sensorial dos morangos termicamente processados (shelf life $=60$ dias) 


\title{
AVALIAÇÃO DA QUALIDADE DAS VARIEDADES CHANDLER E REIKO PARA A OBTENÇÃO DE MORANGO EM CALDA
}

\author{
Candidata : Neila Silvia Pereira dos Santos Richards \\ Orientador: Prof. Dr. João Nunes Nogueira
}

RESUMO

Foram determinadas as características físicas, químicas e sensoriais das variedades Chandler e Reiko, visando avaliar a adequabilidade destas ao tratamento térmico para a obtenção de morangos em calda.

A qualidade da matéria-prima e dos produtos processados foi avaliada submetendo-se amostras às análises de textura, suculência, porcentagem de rendimento (somente para a matéria-prima), pH, acidez total titulável, sólidos solúveis, ácido ascórbico e avaliações sensoriais de cor, sabor e textura.

A susceptibilidade à degradação das antocianinas foi observada no tratamento térmico e durante a estocagem. A retenção desse pigmento é um fator decisivo para a aceitabilidade do morango em calda. A adição de corante contribuiu para a manutenção da cor. Os tratamentos que utilizaram pectina e cloreto de cálcio foram efetivos na manutenção da firmeza dos frutos.

Os resultados mostraram que a variedade Chandler foi a que apresentou as características mais apropriadas para o tratamento térmico, sendo superior à variedade Reiko em textura e cor, principais atributos de qualidade para o morango em calda. 


\section{QUALITY EVALUATION OF THE CHANDLER AND REIKO VARIETIES FOR PROCESSING OF CANNED STRAWBERRIES}

Author: Neila Silvia Pereira dos Santos Richards Adviser: Prof. Dr. João Nunes Nogueira

\section{SUMMARY}

The physical, chemical and sensorial characteristics of the Chandler and Reiko varieties were determined to evaluate their adequability to thermal processing of canned strawberries.

The quality of both the raw material and the final product was evaluated regarding texture, succulency, yield percentage (only for the raw material), $\mathrm{pH}$, titrable acidity, total solids, ascorbic acid content and, also, the sensorial evaluation of color, flavor and texture.

The anthocyanins susceptibility to degradation was observed during thermal processing and storage. The retention of these pigments is a decisive factor for the general acceptance of canned strawberries. The addition of food colorants contributed towards the maintenance of color. Treatments that used pectine and calciun chloride were effective in the maintenance of the firmness of the fruit.

Results showed that the Chandler variety exhibited the most appropriate characteristics for thermal processing, being superior to the Reiko variety in texture and color, the main quality attributes for canned strawberries. 


\section{INTRODUÇÃO}

A origem do cultivo do morango é indiscutivelmente uma história das mais fascinantes. O morango cujo nome científico é Fragaria $x$ ananassa Duch, é derivado da hibridação acidental das espécies do novo mundo Fragaria chiloensis e Fragaria virginiana num jardim botânico europeu há aproximadamente 250 anos. O morango é um pseudo fruto, embora seja considerado como fruto, sendo muito atraente, com textura suculenta e aroma e sabor agradáveis (SCHNEIDER \& SCARBOROUGH, 1960; HANCOCK \& LUBY, 1993).

A partir dos anos sessenta, o morango passou a ser cultivado comercialmente no estado de São Paulo, inicialmente nos municipios de Suzano e Itaquera, depois em Jundiaí e mais tarde em Piedade e Atibaia. Além de São Paulo e Rio Grande do Sul, que são os maiores produtores nacionais da fruta, podem-se encontrar culturas domésticas ou comerciais de morango em várias outras regiões do País. Recentemente, seu cultivo recebeu um forte incentivo e se expande gradativamente no Distrito Federal.

O estado de São Paulo é onde a produção de morango conta com o nível tecnológico mais alto, e conseqüentemente, com os maiores índices nacionais de produtividade. Parte deste sucesso se deve às pesquisas realizadas pelo Instituto Agronômico de Campinas (IAC) na seleção e adaptação de novas variedades de morango. No Rio Grande do Sul são produzidas, em média, três toneladas de morango por hectare, enquanto em São Paulo este indice chega a atingir a faixa de trinta a trinta e cinco toneladas por hectare (PADOVANI, 1991). 
O desenvolvimento de pesquisas tem permitido, de ano para ano, que os índices de produtividade aumentem ainda mais, principalmente no estado de São Paulo. Recentemente, foram obtidas safras de até oitenta toneladas por hectare, em condições de cultura muito bem conduzidas e em regiões com todas as características ecológicas propícias. Este nível de produtividade pode ser considerado como excelente, uma vez que os índices da Califórnia, nos Estados Unidos, tidos como os mais altos do mundo, se situam na faixa das sessenta toneladas por hectare (PADOVANI, 1991).

Como as amoras, as cerejas, as framboesas, as uvas, as ameixas, as pitangas $e$ as frutas silvestres em geral, o morango praticamente não amadurece mais depois de ter sido colhido, atingindo a senescência em curto período de tempo. Os frutos, bem acondicionados, podem ser mantidos em boas condições de consumo por cerca de 4 a 6 dias, desde que armazenados a uma temperatura de 0 a $4^{\circ} \mathrm{C}$.

A produção nacional do morango é quase toda voltada para o mercado interno. Nos últimos anos, tem havido exportação em pequena escala da fruta "in natura" ou industrializada (em forma de polpa) para países como a Argentina e o Chile. Segundo alguns analistas, o desenvolvimento de uma cultura comercial de morango no Brasil pode permitir a exportação, a médio prazo, do morango industrializado para os mercados do Japão e dos Estados Unidos, grandes e estáveis consumidores (PADOVANI, 1991).

A aceitação de alimentos processados por parte do consumidor depende principalmente da capacidade destes alimentos em atender as suas expectativas. Atributos organolépticos de qualidade, tais como aparência, sabor $e$ textura, o valor nutritivo e o custo determinam a aceitação ou rejeição dos alimentos, especialmente quando têm por finalidade a de parecer alimentos de consumo tradicional, ou ainda quando se pretende melhorar algumas caracteristicas dos alimentos ditos tradicionais. 
Frutos como o morango são de grande interesse para a indústria alimentícia, principalmente pelo seu aroma e sabor característicos. Bons produtos industrializados e de grande aceitação no mercado, podem ser obtidos a partir deste fruto. No Brasil, o morango é consumido principalmente na forma "in natura".

Um dos produtos que pode ser obtido é o morango em calda. Por se tratar de um produto de ótima aceitação e de fácil processamento, pode ser elaborado sem maiores problemas, tanto na indústria rural como na grande empresa. O aspecto mais importante a ser considerado é o da variedade que deve ser adequada ao tipo de processamento desejado. Em trabalho realizado recentemente (BERBARI, 1992), ficou demonstrado que as variedades Chandler e Reiko apresentam características agronômicas e tecnológicas bastante promissoras. Estas variedades foram adaptadas às nossas condições de cultivo pelo Instituto Agronômico de Campinas (IAC).

No que se refere às caracteristicas agronômicas observam-se: a boa produtividade e colheita regular todos os anos, a alta porcentagem de flores perfeitas e com pequena tendência a produzir frutos sem sementes, resistência ao transporte e resistência às pragas e doenças. Dentre as características tecnológicas destacam-se: o tamanho e forma uniformes, textura firme e resistência ao processamento térmico, cor vermelha intensa e uniforme na polpa, sabor e aroma agradáveis e, especialmente, a equilibrada relação Brix/acidez total titulável. Esses fatores reunidos, por si só, selecionam as inúmeras variedades existentes, reduzindo-as consideravelmente em número, quando se pensa na industrialização do morango em calda.

Dentre as características organolépticas, o sabor e o odor têm uma importância vital na qualidade de um produto. Estes fatores são sensivelmente afetados durante o processamento, ou seja, as caracteristicas intrínsecas da matéria-prima podem se tornar mais evidentes, principalmente pela possibilidade de liberação de componentes que permaneciam ligados; podem ocorrer, e 
normalmente ocorrem, perdas. Estas perdas geralmente diferenciais em função da intensidade do processamento térmico podem provocar alterações estruturais dos componentes responsáveis pelo sabor e aroma.

Desta forma, utilizando variedades selecionadas e desenvolvendo uma tecnologia adequada para a obtenção de morango em calda, tornar-se-á possivel oferecer tanto ao mercado interno como ao externo um produto de alta qualidade, beneficiando diretamente as indústrias, produtores e consumidores. 


\section{OBJETIVO E METAS}

O presente projeto teve por objetivo avaliar a qualidade das variedades Chandler e Reiko para a obtenção de morango em calda, visando um maior aproveitamento da produção, bem como suprir tanto o mercado interno como o externo com um produto de qualidade que possa atender às exigências dos consumidores. 


\section{REVISÃO DE LITERATURA}

\subsection{Considerações gerais}

Os morangos têm amplas possibilidades de uso, porém, nem sempre se reconhece que as melhores variedades para um determinado propósito industrial podem não ser, necessariamente, as melhores para outro. Por exemplo, na fabricação de sorvetes deseja-se uma fruta de cor vermelho forte e aroma intenso; em enlatados e conservas, prefere-se um vermelho forte homogêneo (inclusive internamente), que apresente textura firme e com gosto de sub-ácido a ácido, enquanto que no mercado da fruta fresca, predomina um gosto meio ácido e a textura não é tão importante (GARROTE \& BERTONE, 1976).

- Os morangos são bastante sensiveis à deterioração por fungos, porém, podem ter a sua boa qualidade conservada durante alguns dias, quando logo após a colheita são refrigerados a temperaturas abaixo de $10^{\circ} \mathrm{C}$, se bem que a melhor temperatura para sua conservação se situe entre 0 e $4^{\circ} \mathrm{C}$. Sem a refrigeração, essas frutas conservam sua boa qualidade no máximo durante dois dias, quando então se tornam excessivamente moles ou apodrecem rapidamente (BLEINROTH et al., 1978).

Cada espécie de fruta pode ter diversas variedades, portanto, podem ocorrer grandes diferenças com relação ao sabor, cor, tamanho, forma, odor, textura, estocabilidade, resistência a danos no transporte, nutrientes, resistência a moléstias, rendimento por área, época de maturação e outras propriedades que irão afetar a adequabilidade da fruta para um determinado método de conservação. Assim, uma variedade de morango pode ser adequada 
para a elaboração de geléias e não sê-lo para outro método de conservação (PASCHOALINO et al., 1979).

Segundo PASCHOALINO (1989), a seleção de variedades, a região de cultivo, as práticas culturais e o estágio de maturação na colheita, bem como o manuseio do produto colhido antes do processamento são fatores importantes a serem considerados, uma vez que a matéria prima é essencial para a qualidade e característica do produto final. A manutenção das características organolépticas do morango inteiro congelado parece estar subordinada a uma condição limite na severidade de transporte e manuseio da matéria-prima. Condições mais severas de transporte conduzem à liberação de suco em maior volume e viscosidade mais alta, o que sugere um mecanismo de destruição celular capaz de liberar, no suco, uma composição de sólidos diferente daquela apresentada pelos frutos transportados em condições mais suaves (PASCHOALINO, 1977).

De acordo com FONSECA \& NOGUEIRA (1984), a procura e aceitação de qualquer produto depende diretamente de sua qualidade. Daí a importância de se empregar no processamento, além de uma matéria-prima de boa qualidade, técnicas que permitam a máxima preservação das características que 0 produto possuía quando no estado fresco. $O$ grau de alteração dos alimentos está condicionado a inúmeras causas, que podem estar ligadas à sua composição, à presença de enzimas e de microorganismos e a outros fatores, capazes de desencadear, neutralizar ou refrear o processo de deterioração (CARUSO \& CAMARGO, 1984; EVANGELISTA, 1987).

Para a industrialização, é necessário adaptar e selecionar variedades, empregar, quando necessário, armazenamento refrigerado, bem como técnicas de processamento satisfatórias, a fim de que se possa oferecer ao mercado consumidor um produto tal que satisfaça as suas exigências, que se tornam cada vez maiores com o passar dos anos. Como regra geral, a excelência de qualquer produto está condicionada à perfeição da matéria-prima utilizada. As frutas para processamento devem ser de tamanho uniforme, razoavelmente livres 
de defeitos, apresentar cor, aroma, textura e sabor adequados. Estes atributos devem ser preservados ao máximo no processamento (FONSECA \& NOGUEIRA, 1984; EVANGELISTA, 1987; PASCHOALINO, 1989).

Através da pesquisa tecnológica foi possivel a adoção de sistemas eficientes e lucrativos de armazenamento e processamento das frutas após colheita, evitando os grandes problemas resultantes da comercialização imediata dos produtos frescos. Segundo GAVA (1985), a maioria dos produtos agrícolas se caracteriza pelo fato de serem sazonais e em determinadas épocas do ano poderá verificar-se o aparente fenômeno da superprodução. Isto, entretanto, não quer dizer que a produção agrícola seja superior à capacidade de consumo, pois o mercado consumidor geralmente se localiza em regiões relativamente distantes dos grandes centros de produção, o que torna o abastecimento com o produto fresco muito mais difícil, exigindo condições adequadas de manuseio, transporte e armazenamento.

Em se tratando de produtos agricolas altamente pereciveis, o melhor aproveitamento das safras só será possivel através da introdução de processos eficientes de industrialização, que permitam a absorção de grande parte das colheitas, possibilitando o seu consumo regular durante todo 0 ano (GAVA, 1985; EVANGELISTA, 1987).

O conteúdo de vitaminas nos alimentos enlatados reflete 0 valor nutritivo das matérias-primas utilizadas, tanto quanto os métodos usados no processamento. Ocorrem algumas perdas de vitaminas durante $\circ$ processamento, porém, caso este seja bem elaborado, essas perdas ficarão no mesmo nivel que as ocorridas durante a preparação caseira do mesmo alimento. Durante o tempo de estocagem, as perdas nutritivas são controladas pela temperatura. As perdas de valor nutritivo, no que se refere a proteínas, lípides e carboidratos, são pouco significativas nos produtos enlatados estocados à temperatura ambiente (FERNANDES, 1982). 


\subsection{Variedades de morango}

As variedades comerciais de morango são octaplóides e hibridas e, geralmente, estão entre as espécies Fragaria virginiana e Fragaria chiloensis. Através de cruzamentos metódicos e pacientes, têm sido criadas novas variedades, multiplicadas por meio de mudas provenientes da divisão da coroa ou dos estolhos formados (CAMARGO, 1960).

De acordo com HANCOCK \& LUBY (1993), as variedades de morango, em sua maior parte, são originárias da Europa e da América Meridional. Dezenas de variedades diferentes ocupavam grandes áreas destes continentes, porém, produziam frutos muito pequenos e de pouco valor comercial. Com a chegada dos europeus em nosso continente, mudas de diferentes variedades americanas foram levadas para o velho mundo sendo, então, submetidas a cruzamentos, dando origem a variedades cada vez melhores. A partir de meados do século passado, com o desenvolvimento da ciência agronômica, estas variedades foram ainda mais aperfeiçoadas, dando origem aos atuais cultivares. Hoje, o morango representa uma atividade econômica de grande importância em diversos países (HYAMS, 1955).

No Brasil, merecem destaque especial as variedades de morango que vêm sendo selecionadas ou adaptadas pelo Instituto Agronômico de Campinas (IAC): IAC-Princesa Isabel, Reiko, Sequóia e Chandler. Recentemente, BERBARI (1992) estudou a viabilidade dessas variedades ao processo de congelação e concluiu que a Chandler e a Reiko foram as mais promissoras, por apresentarem ótimas características para processamento, principalmente em relação ao atributo textura.

Segundo NARUKAMA et al. (1981), duas linhagens de plantas foram selecionadas em 1969, com o objetivo de criar uma nova variedade de morango. Uma foi chamada FS-3, a qual possuia uma coloração vermelha e um excelente sabor. Os frutos desta linhagem foram derivados do cruzamento de 
uma variedade comercial denominada Fukuda, com uma outra variedade "HS-1", que possui um crescimento vigoroso e um formato grande e que foi derivada de uma variedade comercial denominada Harunoka. Em 1973, após o cruzamento de FS-3 e HS-1 com o hibrido "F1", 1300 plantas foram melhoradas. A seguir, conduziu-se uma seleção em viveiro e, finalmente um hibrido F1 (FS-3 x HS-1) 11 foi selecionado. Este hibrido foi chamado "Reiko" que, quando comparado com as variedades Holowase e Harunoka, apresentou maior teor de açúcar, acidez, vitamina $\mathrm{C}$ e melhor sabor.

A variedade Chandler é largamente cultivada nos Estados Unidos da América, para a produção de polpa congelada utilizada na formulação de sorvetes, iogurtes, confeitos e outras sobremesas. No entanto, não foi encontrado na literatura, material bibliográfico referente ao desenvolvimento desta variedade.

O morango é tido como a mais importante das chamadas frutas pequenas, e sua cultura é bastante desenvolvida em vários países do mundo, especialmente nos de clima temperado, onde é muito popular. Entretanto, produz bem em regiões subtropicais e existem muitos casos em que sua plantação é também proveitosa sob condições tropicais (HYAMS, 1965; CAMARGO, 1960; MEDINA et al., 1978).

Como o morango contém ácido salicílico, é recomendado contra o reumatismo, a gota e algumas doenças hepáticas. O açúcar do morango é a levulose, de fácil assimilação. Suas folhas e talos, fervidos, eram indicados em cataplasmas e compressas. O fruto auxilia na diminuição do ácido úrico da urina, reforçando ainda as imunidades naturais e os mecanismos humanos de autodefesa (MEDINA et al., 1978; LANCELLOTI, 1987).

Segundo CAMARGO (1960), apesar do número considerável de variedades, o problema de sua escolha continua a ser o mais delicado na instalação do morangal; isto ocorre porque essa planta é muito sensivel às condições climáticas, especialmente à temperatura ambiente. $O$ trabalho de 
melhoramento do morangueiro é feito com maior intensidade nas regiões mais adiantadas do mundo, e por esta razão, as melhores variedades regionais têm sido lançadas pelas instituições de experimentação e de pesquisa.

\subsection{Fatores que afetam a qualidade do morango}

Segundo ESKIN (1991), a qualidade dos morangos congelados é baseada na cor, caráter (textura) e defeitos, de acordo com padrões dos Estados Unidos. Os numerosos fatores que afetam a qualidade dos morangos frescos e processados começam durante $o$ tempo de plantio e terminam com o consumidor. Sua cor é baseada na superfície externa da fruta inteira e na superfície interna de uma fruta cortada ao meio, e não mais do que $15 \%$ da superfície externa pode estar escurecida (oxidada ou deteriorada). Seu caráter (textura) é baseado na firmeza, grau de integridade, desintegração da fruta e sementes. Recentes estudos têm demonstrado que uma maior aceitabilidade de morangos em conserva e geléias pode ser obtida pela combinação de fruta madura e verde (SISTRUNK et al., 1982; ESKIN, 1991).

Segundo PASCHOALINO (1977), o volume de suco exudado durante o descongelamento é uma medida da intensidade do rompimento de células ocorrido no processamento. Vários pesquisadores associaram variedades de frutas moles e a maturação além do ponto ótimo, com a baixa qualidade do morango congelado. Muitas variações na cultura assim como a chuva, umidade, época de colheita e o manuseio do morango, já foram provados estar relacionados com a firmeza do fruto, tanto "in natura" como congelado. Os frutos são menos firmes imediatamente após uma chuva ou quando colhidos tardiamente. A indicação mais eficiente da melhor variedade para congelamento rápido é a firmeza do fruto imediatamente após a colheita (PASCHOALINO et al., 1973/74). 
Em estudos realizados por ADAMS \& ONGLEY (1973) observou-se que a maioria dos aditivos utilizados na tentativa de estabilizar as antocianinas tinham pouco efeito na razão de degradação da pelargonidina-3-glucosídeo (P3G) sob condições normais de enlatamento ou engarrafamento. Dos vários aditivos testados, o ácido 2-tiobarbitúrico ou altos niveis de sacarose levaram a uma baixa retenção da P3G, enquanto que a cisteína, sulfito de sódio e o abaixamento do $\mathrm{pH}$ na ausência de sacarose adicionada, aumentava a estabilidade do pigmento. Sulfato de sódio tinha um efeito estabilizante na P3G em morangos enlatados e engarrafados, isso devido ou a sua ação antioxidante ou ao fato de que forma compostos adicionais com aldeídos tais como o furfural $e$ o 5-hidrometilfurfural (surgido da quebra dos açúcares), que pode de outra forma se condensar com as antocianinas para formar compostos incolores ou marrons. Outros antioxidantes tais como 0 ácido ascórbico, a tiuréia e o EDTA e agentes bloqueadores de aldeídos tais como o hidroxialanina, o hidroxiclorídrico e o hidrato de hidrazina tinham pouco ou nenhum efeito na razão de degradação de pigmentos.

\subsubsection{Cor}

A cor pode modificar o julgamento da qualidade do sabor e numa escala maior a razão da intensidade do sabor (FRANK et al., 1989). Sabor é a soma das diversas sensações originadas da estimulação dos receptores do gosto, olfato $e$ as fibras nervosas que registram as sensações de tato $e$ sensações químicas. Sabe-se que a cor dos alimentos influencia o sabor (STILLMAN, 1993).

A cor do alimento e outros aspectos de sua aparência fornecem a primeira impressâo e ajudam o consumidor a se decidir sobre sua aceitação ou não. A maioria dos alimentos têm uma cor própria característica $e$, quando esta ou a aparência se desviam demasiadamente da esperada, o consumidor o rejeita. 
Embora a cor não seja um componente nem do sabor nem da textura, é um dos fatores de maior importância na aceitação de um produto. Conseqüentemente, a perda da cor natural é geralmente associada com a perda de qualidade do produto. Investigações têm enfatizado a importância da cor para a qualidade dos morangos. Concentração e tipo de pigmento são fatores chaves que determinam a intensidade da estabilidade da cor. No morango, perda de cor pode acontecer muito rapidamente por causa da extrema instabilidade dos pigmentos antociânicos, tanto em solução como no meio celular. Os dois pigmentos antociânicos de maior importância encontrados no morango são o pelargonidina-3-glucosídeo (P3G) e o cianidina-3-monoglucosídeo (C3MG). 0 P3G é o mais instável dos dois pigmentos e está geralmente presente em maiores quantidades do que o C3MG. Perdas de P3G aparecem como uma mudança definitiva na cor do morango. O C3MG aumenta com o tempo de estocagem, sendo mais estável e, conseqüentemente, contribui para a estabilidade da cor. As conversões do P3G resultam em cianidina. Alguns genótipos contêm porcentagens maiores de C3MG que outros e podem, conseqüentemente, oferecer um meio de criar e selecionar os genótipos com uma maior estabilidade de cor (ESKIN, 1991).

De acordo com SKREDE et al. (1992), durante o processamento e a estocagem de produtos contendo antocianinas, estas são susceptiveis à deterioração da cor devido aos efeitos combinados da degradação e da formação de pigmentos marrons. Quando a deterioração da cor acontece, cria-se um produto visualmente inaceitável. As mudanças podem ser observadas pela análise do pigmento e da cor. De acordo com BAKKER et al. (1992), a instabilidade da cor em produtos de morango é em função da reação de Maillard, escurecimento enzimático, degradação de ácido ascórbico e polimerização das antocianinas da cor vermelha e 0 aumento do escurecimento no suco de morango.

Várias espécies de frutas contêm diferentes tipos de antocianinas que podem, até um certo ponto, influenciar a resistência à perda ou degradação 
da cor (SKREDE et al., 1992). Vários componentes químicos do morango têm sido estudados individualmente para determinar o seu efeito no pigmento P3G purificado. Segundo ESKIN (1991), a razão do desaparecimento do P3G é um sistema modelo seguindo cinética de primeira ordem com alguns açúcares. A glucose e frutose, degradam mais rapidamente o P3G do que a sacarose. Foi observado que a sacarose teve um efeito muito pequeno na cor do suco de morango, enquanto que a frutose afetou de maneira mais pronunciada este atributo durante cinco meses de armazenamento a $4^{\circ} \mathrm{C}$. A glucose aparentemente melhorou a retenção da cor durante o mesmo período de estocagem.

De acordo com CASH \& SISTRUNK (1970) e ESKIN (1991), o conteúdo de oxigênio e a temperatura de estocagem do suco são os principais fatores responsáveis pela perda de cor em suco de morango. A luz causa pouca mudança na cor do suco, porém, em pigmentos extraídos, a cor foi afetada pela luz. O ácido ascórbico, em concentração de $50 \mathrm{mg} / 100 \mathrm{ml}$ resultou numa perda de cor vermelha e no desenvolvimento de uma cor marrom no suco, quando estocado entre 21 e $27^{\circ} \mathrm{C}$.

$\mathrm{O} \mathrm{pH}$ tem maior influência na cor do que a maioria dos componentes, conforme relato de CASH \& SISTRUNK (1970), em estudos realizados com vários cultivares. Com 0 aumento do $\mathrm{pH}$ há uma perda significativa da cor vermelha. Esta perda de cor é acelerada pelo decréscimo do P3G com o aumento do $\mathrm{pH}$. Morangos devem ter um $\mathrm{pH}$ abaixo de 3,51 e uma concentração de pigmentos de 450 a $700 \mathrm{mg} / \mathrm{g}$ de fruta fresca para serem aceitáveis quanto à cor. Qualquer fruta com concentrações de pigmento abaixo de 400 e acima de 850 mg/g são inaceitáveis (ASEN et al., 1969; ESKIN, 1991).

SKREDE (1983) demonstrou que a sacarose é hidrolisada durante o descongelamento do morango dando formação a glucose e frutose. A intensidade desta hidrólise depende do tempo de descongelamento, o que pode explicar a mudança rápida de cor de algumas variedades durante 0 descongelamento. $A$ utilização de glicina aparentemente acelerou o escurecimento durante 0 
processamento térmico de morango e suco de uva. A glicina não afetou o ácido ascórbico e as antocianinas quando o suco era aquecido a $43^{\circ} \mathrm{C}$, porém, rápidas perdas de ambos os componentes ocorreram a $75^{\circ} \mathrm{C}$.

HUDSON et al. (1975b) demonstraram que um descongelamento rápido melhora significativamente a aparência dos morangos, pressumivelmente porque há menos tempo disponivel para ocorrer o gotejamento antes da degustação. A dificuldade de produzir uma melhora geral na qualidade foi percebida. Esta percepção foi mais acentuada com os tratamentos onde deixouse o produto em repouso num xarope, o que significativamente diminuía a cor e a aparência geral, mas tendiam a melhorar o sabor e a textura.

Os dois mecanismos de oxidação das antocianinas de morangos por peróxido de hidrogênio proposto por SONDHEIMER \& KERTESZ (1948) ajudaram a explicar muitas das mudanças na cor durante 0 processamento. $O$ peróxido de hidrogênio surge da oxidação do ácido ascórbico para ácido dehidroascórbico e pode ser reforçada pela oxidação do pigmento. Reações não catalisadas acontecem independentemente do aquecimento a temperaturas mais altas $\left(90^{\circ} \mathrm{C}\right)$ para inativar as enzimas antes da estocagem. A $20^{\circ} \mathrm{C}$ um aumento de íons ferrosos $\left(\mathrm{Fe}^{2+}\right)$ e de ácido ascórbico aceleram a razão de degradação das antocianinas. Os íons $\mathrm{Fe}^{2+}$ catalisam a destruição dos pigmentos, mesmo quando o ácido ascórbico não está presente; porém, aparentemente, precisa-se de ácido ascórbico para manter a velocidade da reação (HANCOCK \& LUBY, 1993).

Segundo ADAMS \& ONGLEY (1973), a polifenoloxidase (PPO) degrada rapidamente as antocianinas em frutas. O emprego do calor é, provavelmente, o método mais simples e mais direto de inativação da PPO, uma vez que enzimas são proteínas e, conseqüentemente, são facilmente desnaturadas pelo calor. Outros métodos para prevenir as mudanças de pigmentos pelas enzimas são: a redução no $\mathrm{pH}$, a redução da atividade de água, a minimização nos níveis de oxigênio e a adição de antioxidantes. A atividade da 
PPO é dependente do $\mathrm{pH}$ e a atividade ótima da enzima varia com a fruta considerada, dependendo ainda do número e tipo de isoenzimas presentes. Manipulações impróprias de frutas podem produzir danos às células e causar a interação entre a PPO endógena e os fenólicos. Neste caso, mesmo após o branqueamento (inativação da PPO), as quinonas e os produtos intermediários da oxidação formados podem ser suficientes para iniciar as reações de oxidação e polimerização que levam à perda de antocianinas (MAIN et al., 1986). A temperatura para a atividade ótima da PPO varia de acordo com as frutas e verduras a serem processadas (ESKIN, 1991).

A complexação metálica dos pigmentos do morango tem sido estudada por vários autores. O pigmento cianidina-3-monoglucosideo (C3MG) tem dois grupos fenólicos vicinais, que podem ser complexados com íons metálicos. Estudando purê de morango, CASH \& SISTRUNK (1970) demonstraram que a cor vermelha era retida a $50^{\circ} \mathrm{C}$ por 24 horas pela adição de baixa concentração de cloreto de alumínio $\left(\mathrm{AlCl}_{3}\right)$, cloreto de estanho $\left(\mathrm{SnCl}_{2}\right)$ e cloreto estânico $\left(\mathrm{SnCl}_{4}\right)$; também, esses íons metálicos, especialmente o último, preveniram a oxidação do ácido ascórbico. Pouca mudança na cor do purê de morango ocorre quando o cloreto de alumínio $\left(\mathrm{AlCl}_{3}\right)$ é adicionado a um $\mathrm{pH}$ de 3,0 a 3,4, porém, na presença de íons estanho $\left(\mathrm{Sn}^{2+}\right)$ e estânico $\left(\mathrm{Sn}^{4+}\right)$, uma cor purpúrea-avermelhada estável se desenvolve. Estes resultados conflitam com pesquisas feitas por ASEN et al. (1969) nas quais o comprimento de onda da solução de C3MG mudou de 515 para $545 \mathrm{~nm}$ numa faixa de $\mathrm{pH}$ de 3,0 a 3,5, quando o $\mathrm{AlCl}_{3}$ era adicionado.

As transformações das antocianinas $e$ os mecanismos de degradação da cor em produtos de morango tais como conservas, geléias e sucos concentrados foram intensivamente estudados por SPAYD \& MORRIS (1982) e SPAYD et al. (1982). A mudança de cor em produtos concentrados de morango é atribuída à degradação de antocianina monomérica para polimérica. Os pigmentos poliméricos são solúveis em hidróxido de sódio ( $\mathrm{NaOH} 1 \mathrm{~N})$ e o emprego de aditivos químicos pode diminuir a formação desses pigmentos no 
purê durante a estocagem. A adição de hidróxido sulfito de sódio $\left(\mathrm{NaHSO}_{3}\right)$, ácido cítrico e $\mathrm{SnCl}_{2}$ em morangos mecanicamente colhidos e congelados melhoraram a cor após o congelamento, estocagem e descongelamento.

Segundo SPAYD et al. (1982), a perda de cor no purê de morango não foi significativamente afetada pela peroxidase ou polifenoloxidase quando o nivel de atividade enzimática estava dentro dos limites encontrados naturalmente nos dois tipos de morangos testados (maduros e verdes). Baixo $\mathrm{pH}$ e possivelmente inibidores reduziram a eficácia da peroxidase e polifenoloxidase em degradar as antocianinas nos purês de morango. A adição de frutas verdes, que contêm niveis mais elevados de peroxidase e polifenoloxidase, compostos fenólicos e clorofila, ao purê de morango maduro não afetou a estabilidade da cor da geléia de morango estocada por um ano a 2,25 e $35^{\circ} \mathrm{C}$. Frutas verdes contêm, ainda, menor quantidade de sólidos solúveis, cor mais pobre e maior quantidade de fenóis totais (SPAYD \& MORRIS, 1981; SPAYD \& MORRIS, 1982).

CHICHESTER (1982), após pesquisas visando a estabilidade da cor de xaropes de morango e amoras, observou que, durante o processamento e estocagem de produtos contendo antocianinas, estes são susceptíveis de deterioração devido aos efeitos combinados da degradação e da formação de pigmentos escuros. Morangos, quando comparados com amoras, têm menor quantidade de ácido ascórbico e pigmentos, sendo que a concentração de antocianinas no morango é de $10 \%$ daquela na amora. A razão da degradação da antocianina livre foi duas vezes maior no caldo de morango do que no caldo de amoras. A quantidade total de pigmentos antociânicos é também um fator muito importante. As diferenças na estabilidade que têm sido observadas para diferentes tipos de antocianinas é menos importante do que a concentração total de antocianinas.

BAKKER \& BRIDLE (1992) estudando a cor de sucos de morango, demonstraram que a reação de Maillard, o escurecimento enzimático, a degradação do ácido ascórbico e a polimerização das antocianinas com outros 
fenólicos podem contribuir para a perda da cor vermelha e o aumento do escurecimento no suco de morango. Especificamente, a interação do ácido ascórbico com as antocianinas e a subseqüente degradação mútua de ambos é um problema importante, visto que a maioria dos produtos contém altas concentrações de ácido ascórbico. Condições que favorecem a oxidação aeróbica do ácido ascórbico causavam uma perda máxima de antocianinas; mas quando o oxigênio era removido, não se percebia nenhuma deterioração de cor. $O$ efeito sinérgico entre $O$ ácido ascórbico e o oxigênio na degradação dos pigmentos foi registrado. A ausência do oxigênio evita a perda de antocianinas durante $\circ$ processamento. Estudos realizados demonstraram perda de pigmentos de até $60 \%$ em 24 horas à temperatura ambiente em sistemas modelos contendo P3G, catecol e PPO. Estes resultados sugeriram que as quinonas e os produtos formados nas reações intermediárias como resultado da atividade da PPO podiam ser suficientes para iniciar as reações de oxidação e polimerização que levaram a uma perda ainda maior das antocianinas.

HUDSON et al. (1975a), trabalhando com morangos congelados, descobriram que o ácido cítrico foi efetivo para obter uma melhor cor e maior retenção de ácido ascórbico. $\mathrm{O}$ pH é a única medida objetiva correlacionada com a qualidade da cor e um pH de 3,51 ou menos é necessário para uma qualidade aceitável nos morangos após o congelamento. As antocianinas dos morangos são mais estáveis no $\mathrm{pH} 1,8$; porém, abaixo disso, acredita-se que 0 escurecimento induzido pelas reações entre os açúcares e os pigmentos são mais importantes que a estabilidade dada ao pigmento antociânico pelo baixo valor de $\mathrm{pH}$.

A co-pigmentação tem um papel crucial na pigmentação de frutas e flores. Observações atuais mostram que os co-pigmentos desempenham um papel igualmente crucial na coloração de vinhos tintos. Os co-pigmentos, por si só, têm pouca ou nenhuma cor, mas, quando adicionados a uma solução de antocianinas aumentam em muito a cor (LIAO et al., 1992; ROMMEL et al., 1992). 
Segundo TOLEDO \& GUERCHON (1990), sob o ponto de vista tecnológico, são inegáveis os benefícios alcançados com o uso de aditivos em alimentos. Existe uma preocupação constante quanto aos riscos toxicológicos potenciais da ingestão diária dessas substâncias químicas.

A cor dos alimentos é um dos mais importantes atributos de qualidade e está sujeita a grandes mudanças que não são facilmente controláveis. Portanto, para controlar a aparência dos alimentos é necessário adicionar corantes artificiais. Em anos recentes, a segurança de corantes artificiais, em particular o vermelho $n^{\circ} 2$ tem sido questionada, e como resultado disso o seu uso no futuro será limitado, se não eliminado. Também, o controle das cores nos produtos derivados das frutas é geralmente difícil de conseguir, devido à não uniformidade da cor em produtos frescos (HANCOCK \& LUBY, 1993).

As antocianinas são, provavelmente, os mais conhecidos pigmentos naturais dos alimentos e são eles que fornecem as cores vermelha e azul a muitas frutas e flores. Porém, apesar da sua óbvia familiaridade, eles não têm sido muito utilizados como corantes de alimentos, além disso, as limitações das antocianinas em exibirem cores em pH ácido, a sua não disponibilidade comercial e a dificuldade na purificação a partir de fontes naturais são algumas das razões que restringem as suas aplicações como corantes de alimentos (HANCOCK \& LUBY, 1993).

A estrutura e a estabilidade das antocianinas têm sido estudadas devido ao crescente interesse em corantes naturais para alimentos. As antocianinas não são muito estáveis em frutas e derivados de frutas, podendo ser descoloridas por sistemas enzimáticos e degradadas por oxigênio molecular. Podem ser facilmente convertidas de sua cor natural característica, vermelha ou azul, para compostos amarronzados indesejáveis. Provou-se que muitos fatores durante o processamento e estocagem influenciam a degradação dos pigmentos. Os principais fatores que afetam a degradação das antocianinas incluem a 
temperatura, o pH, compostos fenólicos, açúcar, produtos de degradação do açúcar, oxigênio e ácido ascórbico (CEMEROGLU et al., 1994).

Corantes são substâncias que transmitem aos alimentos novas cores ou exaltam as que eles já possuem, com a finalidade de melhorar o seu aspecto (EVANGELISTA, 1987). Existem casos nos quais o uso de corantes alimentares é justificado (SIMÃO, 1989).

Com relação aos corantes naturais, sua origem é quase exclusivamente vegetal, exceção feita a cochonilha (cochenille), obtida à partir de corpos dessecados das fêmeas do inseto Coccus cacti. A cochonilha contém um corante vermelho brilhante, o ácido carmínico (GAVA, 1985; EVANGELISTA, 1987; SIMÃO, 1989). De maneira simples, os corantes podem ser agrupados em corantes naturais e sintéticos. Os corantes naturais podem ser usados sem limitação da quantidade e o rótulo do produto deve apresentar o código C.I.. Pelo decreto $n^{\circ} 55871$, permite-se 0 uso de cacau, carotenóides, beterraba, antocianinas, urucum, cochonilha e outros (GAVA, 1985).

Antocianinas são pigmentos de cor vermelha, azul e violeta, encontrados em flores, frutos e folhas. Sob o ponto de vista químico, são glicosidios que, por hidrólise, fornecem duas unidades de carboidratos e uma aglicona. A aglicona é denominada antocianidina (SIMÃO, 1989).

De acordo com TAKAHASHI (1987), carmim é uma laca de alumínio ou cálcio-alumínio obtido de um extrato aquoso de cochonilha. A matéria corante deriva do ácido carmínico.

Segundo MORI et al. (1993), muitos corantes sintéticos para alimentos, o vermelho em particular, foram banidos do uso em produtos alimentícios devido à toxicidade. Isto promoveu uma pesquisa para corantes alimentícios extraídos de fontes naturais. A produção de pigmentos antociânicos de ocorrência natural é uma alternativa em potencial para agentes colorantes 
sintéticos vermelhos. Com os avanços recentes na biotecnologia das plantas, vários metabólitos secundários, incluindo as antocianinas, podem ser produzidos em culturas de células. Entre as várias culturas estudadas existem as cenouras, batatas doce e morangos.

Corantes artificiais, em particular, têm sido objeto de muitas críticas, pelo fato do seu emprego ser desnecessário em grande variedade de alimentos, justificando-se seu uso apenas por questão de costume e hábitos alimentares. Em geral, o emprego de corantes em alimentos se apoia na importância da aparência do produto para a sua aceitabilidade visando atingir, principalmente, o consumidor infantil, que é muito atraído por cores (TOLEDO \& GUERCHON, 1990).

O corante amaranto é muito utilizado nos produtos de sabor cereja ou morango. Os corantes artificiais têm sido constantemente reavaliados com respeito à sua inocuidade (TOLEDO \& GUERCHON, 1990). Sob o ponto de vista toxicológico, o corante sintético amaranto está classificado na categoria $A$, ou seja, corantes que são aceitáveis para serem empregados em alimentos, possuindo; segundo a legislação, uma ingestão diária admissivel para o homem em $\mathrm{mg} / \mathrm{kg}$ de peso corporal de 0 a 1,5 . Em relação à função química, são classificados como corantes monoazóicos, sendo importantes em relação à freqüência de seu uso. Recentes estudos colaborativos de três laboratórios, com relação a teratogenicidade, usando duas variedades de ratos, não revelaram nenhum efeito adverso, quando administraram o amaranto a $200 \mathrm{mg}$ por $\mathrm{kg}$ de peso corporal diariamente. O Comitê Misto da FAO/OMS (peritos em aditivos alimentares) admitiu a possibilidade de que a estrutura deste composto não indica que seja potencialmente carcinogênico quando ingerido oralmente (SIMÃO, 1989).

No Colour Index, os corantes são identificados por meio de números contendo cinco algarismos. O amaranto é classificado como C.I. 16185 FD \& RED $n^{\circ} 2$. No Diário Oficial da União (14/05/71), estabeleceu-se a porcentagem 
de limite máximo em 0,01 no produto a ser consumido. Deve-se proceder com o máximo rigor ao se tratar de corantes, não só quanto ao aspecto qualitativo, mas também o quantitativo, pois, do contrário, será ignorado o enorme esforço dos especialistas e legisladores em aditivos. De acordo com a legislação brasileira, os corantes estão presentes em balas, gelatinas, sorvetes, refrescos, refrigerantes etc., alimentos especialmente preferidos por crianças (SIMÃO, 1989).

Em estudos realizados por KOLEV et al. (1974), foram testados corantes sintéticos (Ponceau 6P, Eritrosina, Erdbeenot, Amaranto, Cochonilha, Carmim, Azorubi e Escarlates) do ponto de vista de suas propriedades para colorir morangos enlatados. De acordo com os resultados, Erdbeenot e Cochonilha foram os mais apropriados, com máxima absorção na faixa de 500$505 \mathrm{~nm}$. Estes corantes continham antocianinas em concentrações iguais ou bem maiores do que as encontradas no morango. A estabilidade dos corantes na solução de açúcar em pH 3,3 foi muito alta, porém, decresceu consideravelmente quando a solução estava em contato com a superfície exposta da lata. Visualmente, Cochonilha, Erdbeenot e Ponceau 6P deram os melhores resultados.

\subsubsection{Textura}

Segundo MAIN et al. (1986) a textura dos morangos é dependente das pectinas, da celulose e das mudanças que ocorrem nestes constituintes durante a maturação, a estocagem pós-colheita e o processamento.

As mudanças na textura são fontes de reclamação dos consumidores quando da aquisição de produtos tais como frutas fatiadas e inteiras congeladas, conservas e coberturas. A perda nas caracteristicas pode ser limitada ao se escolher um cultivar mais firme, numa maturidade ótima, minimizar o tempo de estocagem e evitar danos físicos durante a lavagem e o 
processamento. A futura indústria de morangos, em ambos os produtos frescos e processados, dependerá muito do desenvolvimento de novos cultivares que tenham altos rendimentos, resistência a doenças e alta qualidade incluindo cor uniforme e firmeza (ESKIN, 1991).

SISTRUNK et al. (1960) investigaram o efeito de variedade, época de colheita, tempo e temperatura de manuseio dos frutos após a colheita e a velocidade de congelamento, sobre as quebras das fatias de morango cortado e misturado com açúcar. Concluíram que as variedades se comportam de maneira diferente quanto à quantidade de quebras. Os frutos colhidos precocemente tinham menor tendência para quebra do que aqueles colhidos tardiamente; e o manuseio prolongado dos frutos, após a colheita, resultava em frutos moles.

As modificaçōes na textura do morango durante a senescência têm sido atribuídas às mudanças na atividade iônica da lamela média (NEAL, 1965; BARNES \& PATCHETT, 1976). lons cálcio normalmente ocorrem entre as células (lamela média) e formam ligações cruzadas entre os grupos carboxilicos de cadeias adjacentes. A quelação desses íons cálcio pode levar ao amolecimento do tecido. Soluções contendo íons de cobre, magnésio e cálcio são, portanto, efetivas em reestruturar 0 tecido do morango após o amolecimento inicial. MORRIS et al. (1985) demonstraram que a imersão de morangos por um minuto em soluções contendo lactato de cálcio a $0,5 \%$ ou lactato de cálcio a $0,5 \%$ mais ácido cítrico a $1 \%$ melhorava a firmeza dos frutos termicamente processados e/ou congelados e descongelados. A técnica do vácuo tem sido usada para melhorar a incorporação de açúcares e agentes firmadores nos tecidos do morango (MAIN et al., 1986).

MAIN et al. (1986) desenvolveram estudos para verificar os efeitos de soluções de lactato de cálcio e celulose microcristalina na qualidade e características de morangos maduros congelados. Após o congelamento e descongelamento ficou demonstrado que os tratamentos de imersão, com exceção do lactato de cálcio a $1 \%$, aumentaram a firmeza do morango. Frutos 
inteiros eram mais firmes do que frutos fatiados. De acordo com os autores, frutos termicamente processados que foram mantidos em soluções de lactato de cálcio a $1 \%$ e $2 \%$ (com e sem vácuo), apresentavam uma resistência maior ao corte do que $o$ fruto controle. $O$ fruto inteiro manteve a sua integridade melhor do que $o$ fruto fatiado, após o processamento térmico. $O$ efeito interativo dos tratamentos mostrou que o lactato de cálcio foi mais eficiente em firmar os frutos fatiados do que os frutos inteiros, conforme determinado pelos testes de cisalhamento. Isto provavelmente foi devido à maior área superficial da fruto fatiado, favorecendo assim a penetração do cálcio. A avaliação sensorial não detectou diferenças de sabor e nem de textura entre os tratamentos empregados.

SZCZESNIAK \& SMITH (1969) afirmaram que a grande susceptibilidade dos morangos aos danos na textura não é surpreendente quando se considera seu conteúdo extremamente baixo de sólidos, o que faz com que eles tenham uma estrutura polimérica muito intrincada, capaz de suportar uma grande quantidade de líquido. De acordo com MAIN et al. (1986), para que o cálcio seja um efetivo agente firmador, pectinas de baixo grau de metoxilação devem estar presentes. A maior eficiência do cálcio como agente firmador ocorre durante o processamento térmico, condição que favorece a desesterificação das cadeias de pectina. Por esta razão, o cálcio é mais eficiente em firmar frutos termicamente processados do que frutos congelados.

Em estudos realizados por HUDSON et al. (1975b), nos quais morangos foram deixados em repouso num xarope de sacarose antes de serem congelados, observou-se que houve um aumento na firmeza dos frutos. Esta firmeza pode ser o resultado de uma maior penetração do xarope. É possivel que a melhoria da firmeza seja causada por um aumento na perda por gotejamento e uma conseqüente compressão dos tecidos. 


\subsection{3. Ácido ascórbico}

Segundo ESKIN (1991), o ácido ascórbico é um dos componentes mais importantes e pesquisados em morangos. As frutas frescas são fontes ricas dessa vitamina, fornecendo de 50 a $90 \mathrm{mg} / 100 \mathrm{~g}$, valores estes que variam grandemente entre cultivares e condições de crescimento. BERBARI (1992) encontrou teores de ácido ascórbico da ordem de 152 e $162 \mathrm{mg} / 100 \mathrm{~g}$, respectivamente, para as variedades Chandler e Reiko. Segundo ESKIN (1991), condiçōes de campo, cultivar, estado de maturação, estocagem pós-colheita e processamento afetam o conteúdo de ácido ascórbico nos morangos. As frutas frescas são uma fonte rica dessa vitamina. O sombreamento das plantas durante a maturação diminui o teor de ácido ascórbico, bem como o conteúdo de ácido cítrico. Parece haver uma possibilidade de selecionar e escolher frutas altamente coloridas com altos valores de ácido ascórbico. Pigmentos antociânicos podem ser degradados independentemente das mudanças no ácido ascórbico; porém, em sucos sem aditivos químicos, aumentando-se o teor de ácido ascórbico acelera-se a perda de pigmentos.

No estudo realizado por MAIN et al. (1986), observou-se que os morangos tratados com lactato de cálcio $2 \%$ (com ou sem vácuo) apresentaram conteúdo mais baixo de ácido ascórbico do que o controle (vácuo mais água). Morangos fatiados continham significativamente menos ácido ascórbico que os morangos inteiros, devido à exposição e oxidação e, adicionalmente, à lavagem.

Segundo CHICHESTER (1982), o ácido ascórbico tem um efeito negativo na estabilidade dos pigmentos. Nos xaropes de morango, a adição de ácido ascórbico aumentou a razão de degradação das antocianinas e causou uma degradação mais extensa em valores de Hunter. Também resultou num aumento significativo do índice de escurecimento. Uma condensação entre ácido ascórbico e antocianinas foi sugerida como sendo a reação inicial. Já, com a adição de antocianinas ao xarope, observou-se um leve efeito protetor para o ácido ascórbico. 
PASCHOALINO (1977), estudando os fatores que influem sobre a qualidade de morangos congelados, demonstrou que a presença do ácido ascórbico no xarope de morangos teve influência positiva sobre as características organolépticas do produto. Verificou-se uma melhora na cor, sabor e textura do produto, mesmo ao nivel de $0,1 \%$ de ácido ascórbico. A viscosidade do xarope apresentou-se mais alta para maiores concentrações de açúcar, parecendo ter havido maior liberação de suco para o xarope. A cor desenvolvida no xarope apresentou-se vermelha mais intensa para maiores concentrações de açúcar, provavelmente pelo maior volume de suco exudado (pigmentos no suco) e pelo efeito do antioxidante.

\subsubsection{Outros fatores importantes}

Fatores como a maturação, a época de colheita, a porcentagem de umidade, o controle de pragas e doenças e o clima da região também afetam a qualidade das frutas (GOMES, 1973b; GAVA, 1985; EVANGELISTA, 1987).

Segundo ESKIN (1991), a manipulação correta dos frutos e a manutenção deles a baixas temperaturas durante 0 transporte e a estocagem, antes de serem processados ou comercializados, são extremamente importantes. A firmeza e a maturação dos frutos têm influência nas características do morango congelado. Embora os morangos plenamente maduros tenham maiores quantidades dos pigmentos pelargonidina-3-glucosídeo (P3G) e cianidina-3monoglucosídeo (C3MG) do que morangos firmes, a maturação não parece ter efeito significativo nas porcentagens relativas entre os dois pigmentos (CASH \& SISTRUNK, 1970).

SPAYD \& MORRIS (1982) verificaram um aumento no teor de pectinas e uma diminuição na quantidade de celulose e de protopectina durante a maturação do morango, partindo do fruto verde pequeno até o estágio de completamente maduro. 
HUBER (1984) concluiu que, tanto as substâncias pécticas como as hemiceluloses são importantes para a textura do morango. Mudanças observadas não foram aparentes durante o estágio inicial do crescimento; porém, é evidente que não estão relacionadas com o crescimento em si, e sim, envolvidas nas mudanças de textura associadas com o amadurecimento. WOODWARD (1972) registrou uma tendência similar para as substâncias pécticas do morango, mas concluiu que parte da perda total dessas substâncias ocorre durante os estágios finais do amadurecimento.

WROLSTAD et al. (1990) demonstraram que a influencia positiva da sacarose pode ser em função desta funcionar como um inibidor da PPO, interferir com as reações de condensação. São muitas as reações de condensação em potencial que poderiam contribuir com a polimerização de pigmentos e com o escurecimento, tais como a condensação antocianina fenólica, a reação de Maillard e a degradação do ácido ascórbico. A densidade da cor não foi significativamente influenciada por qualquer tratamento de adição de açúcar. As antocianinas monoméricas, os polimeros antociânicos degradados e os pigmentos escurecidos contribuíram para a densidade da cor (FORNEY \& BREEN, 1986).

De acordo com PASCHOALINO (1977), nenhuma diferença significativa em cor, sabor e textura do morango ficou evidenciada quando se congelou o fruto em xaropes de sacarose variando de 30 a $50^{\circ}$ Brix. A coloração desenvolvida no xarope após descongelamento total não apresentou variação para os diferentes tratamentos submetidos, e nenhuma preferência foi destacada pelo grau de doçura do produto.

Em estudos realizados por ESKIN (1991) observou-se que, mergulhando o fruto em $2 \%$ de pectina, houve um aumento do peso drenado da ordem de $33 \%$. A etapa de preparação dos frutos para o congelamento deve ser feita rapidamente, de modo a não causar danos excessivos. $O$ congelamento deve ser feito imediatamente após misturar o fruto com açúcar e hidrocolóides, 
para que seja reduzida a perda por gotejamento e os frutos permaneçam mais firmes após o descongelamento, isto vale para frutos inteiros e fatiados.

Segundo ESKIN (1991), o pH contribuiu mais para a estabilidade da cor dos morangos do que a maioria dos outros componentes. Morangos devem ter um $\mathrm{pH}$ abaixo de 3,51 . Quando $\mathrm{opH}$ for superior a este valor ocorre uma maior degradação das antocianinas. Em frutas congeladas, a atividade da PPO é dependente do $\mathrm{pH}$ e a atividade ótima da enzima varia, dependendo do número e tipo de isoenzimas. A atividade da PPO cessa a um pH de aproximadamente 3,0 e a destruição das antocianinas é acelerada quando o pH aumenta para 4,0. De acordo com HANCOCK \& LUBY (1993), a razão da destruição dos pigmentos de antocianinas é acelerada por $\mathrm{pH}$ alto, oxigênio, temperaturas altas, ácido ascórbico, açúcar, enzimas e outros compostos. A cor exibida pelas antocianinas é geralmente influenciada pelo $\mathrm{pH}$ do meio; numa faixa de $\mathrm{pH}$ ácido, pigmentos de antocianinas existem inteiramente na forma de um sal vermelho. Quando o $\mathrm{pH}$ é aumentado para a faixa de 4 a 5 , a solução torna-se incolor. A descoloração é causada pela transformação do sal flavilium de cor vermelha para uma base carbinol, tal como cromoenóis. Após um novo aumento de $\mathrm{pH}$, desenvolve-se uma cor roxa devida a anidrobase quinoindol das antocianinas. Num pH de 7 a 8 , a anidrobase torna-se ionizada e os pigmentos exibem uma cor azul escura ou uma cor amarela se desenvolve devido à formação de chalconas.

De acordo com MARTIN (1965), na indústria de alimentos enlatados, exaustão a calor significa aquecimento da lata e seu conteúdo antes da recravação. Um dos objetivos mais importantes da exaustão consiste em remover $O$ ar do produto enlatado. O segundo objetivo consiste em produzir vácuo para impedir pressões inadequadas na lata durante o processo de esterilização. O vácuo consiste na diferença de pressão interna e externa da lata. O valor indicado no vacuômetro é em função da pressão da lata e da pressão atmosférica do local. $O$ vácuo normal numa lata de compota geralmente gira em torno de 8 a 15 polegadas, variando de acordo com a temperatura e o tempo de fechamento. $O$ vácuo depende também do espaço livre nas latas, sendo então, 
sempre necessário que se mantenha um espaço constante, para obter uniformidade do vácuo nas latas. Quanto maior a quantidade de ar no espaço livre, maior será a pressão interna e, portanto, menor o vácuo. A determinação do vácuo por meio de vacuômetro é uma das principais determinações físicas na estabilidade do produto.

De acordo com JACKIX (1988), o vácuo recomendado para produtos enlatados é acima de $10 \mathrm{pol} . \mathrm{Hg}$. A legislação brasileira exige para frutas em calda $300 \mathrm{~mm} \mathrm{Hg}$ (11 pol. $\mathrm{Hg}$ ). Em linhas gerais, o processo a vácuo consiste na retirada do ar da embalagem e posterior recravação, procurando-se manter um ambiente anaeróbico. Este processo procura manter um volume mínimo de ar dentro da lata (MARTIN, 1965).

\subsection{Conservação pelo calor}

De acordo com GARROTE \& BERTONE (1976), o objetivo da preservação dos alimentos é manter as propriedades naturais dos mesmos. Como as frutas são organismos vivos, a preservação completa de suas propriedades originais requereria a manutenção de sua estrutura celular e de suas propriedades intactas a nivel de citoplasma e membranas celulares.

Dos processos de conservação pelo uso do calor, o tratamento térmico (esterilização) em recipientes hermeticamente fechados é, atualmente, o de maior importância industrial, mundialmente empregado, não só na grande indústria, como também na produção doméstica. $O$ comércio de frutas em calda tem aumentado consideravelmente nas últimas décadas (MARTIN, 1965; GAVA, 1985).

Segundo SOLER et al. (1982), dentre os diversos produtos que podem ser obtidos das frutas, em geral, destaca-se o da fruta em calda, que é considerado como produto de primeira linha nas indústrias de conservas de 
frutas e de larga aceitação pelos consumidores em todos os continentes. Por definição, a fruta em calda é o produto obtido de frutas inteiras ou em pedaços, com ou sem sementes ou caroços, com ou sem casca, submetidos a cozimento incipiente, enlatadas ou colocadas em vidros, praticamente cruas, cobertas com calda de açúcar. Depois de fechado em recipientes, o produto é submetido a um tratamento térmico adequado (PADOVANI, 1991).

Para a obtenção de morango em calda de pseudo frutos inteiros, que é a mais comum, PADOVANI (1991) citou que, além da boa produtividade e resistência a moléstias, os frutos devem apresentar as seguintes características: tamanho e forma uniformes; elevado rendimento; textura firme e resistência ao processamento térmico; cor da polpa intensa e uniforme; uniformidade das características químicas, notadamente da relação Brix/acidez total titulável; sabor e aroma agradáveis e próprios da fruta.

A calda, também chamada de líquido de cobertura, deve ser usada para preencher os interstícios, o que facilita a transmissão de calor, promove a remoção de ar e realça o sabor das frutas (MARTIN, 1965; JACKIX, 1988). A concentração da calda (xarope) depende da fruta, principalmente da sua acidez (MARTIN, 1965). De acordo com JACKIX (1988), após a adição da calda na lata, inicia-se uma troca osmótica, com entrada de sólidos solúveis no fruto. Portanto, com o passar dos dias, a concentração da calda diminui até atingir o ponto de equilíbrio. A concentração final da calda depende da relação de peso entre calda e fruto e da concentração de açúcar do fruto e da calda.

Além da contaminação por metais, as causas mais importantes da deterioração de qualidade de alimentos enlatados são as mudanças químicas que ocorrem vagarosamente durante a estocagem. São responsáveis por alterações no valor nutritivo e na qualidade estética do produto. Entretanto, os compostos formados nessas reações, em sua maioria, não são danosos à saúde, resultando apenas em prejuizo à qualidade do produto. As mudanças organolépticas e nutricionais dependem não só do tempo, mas também da 
temperatura. Ocorrem na seguinte ordem: sabor e aroma, cor, textura e, muito mais tarde, perdas nutritivas (FERNANDES, 1982).

Deve-se fazer uma avaliação do aspecto externo da embalagem, com relação à corrosão e amassamento. $O$ manuseio inadequado e a corrosão externa podem afetar a integridade dos alimentos enlatados. A corrosão externa pode ser favorecida por umidade, acidez, alcalinidade e presença de eletrólitos. As latas devem ser estocadas secas, e a cola dos rótulos não deve conter materiais corrosivos. Durante as diversas operações, o manuseio das latas deve ser cuidadoso. Deve-se evitar amassamento, tanto das latas vazias como das cheias, para não prejudicar a aparência e, principalmente, a alteração do selo hermético (JACKIX, 1988). 


\section{MATERIAL E MÉTODOS}

As atividades desta pesquisa foram conduzidas no Laboratório do Departamento de Ciência e Tecnologia Agroindustrial da Escola Superior de Agricultura "Luiz de Queiroz" - USP - Campus de Piracicaba.

Frutas em calda como pêssego, figo, abacaxi, etc., geralmente apresentam uma vida-de-prateleira ("shelf life") de 6 a 12 meses, o que não é válido para o morango, uma vez que ocorre uma grande perda da cor. Empresas no Rio Grande do Sul processam o morango em calda no início do mês de dezembro para ser colocado em cestas de Natal e consumido até o final do mês de janeiro, tendo um "shelf life" estimado em quatro meses, embora o consumo ocorra muito antes deste prazo (aproximadamente um mês). A estimativa do "shelf life" é em função das reações que acontecem, deteriorando, principalmente, a aparência do produto, sendo a cor o principal critério de qualidade.

A análise sensorial, neste trabalho, foi realizada aos 60 dias (dois meses após o processo), uma vez que após esta data as reações não enzímicas estão bastante aceleradas e chegam, algumas vezes, dependendo do tratamento, a descaracterizar o produto tornando-o inaceitável para os consumidores, especialmente com relação à cor. Para verificar o comportamento físico-químico, as análises foram estendidas até 180 dias após o processamento. 


\subsection{Matéria-prima}

No presente trabalho foram utilizadas as variedades de morango Chandler e Reiko.

Foram recebidos no laboratório do Departamento de Ciência e Tecnologia Agroindustrial, lotes de $60 \mathrm{~kg}$ de morango (Fragaria $x$ ananassa Duch.) de cada uma das variedades em estudo, provenientes da cidade de Piedade, estado de São Paulo, através de doação dos Srs. Tatuo e Oswaldo Saziki, contactados pelos pesquisadores do Instituto Agronômico de Campinas.

As variedades Chandler e Reiko foram selecionadas para a realização do presente projeto de pesquisa, por se tratarem de variedades em fase de implantação no estado de São Paulo, não estando, até então, incluídas em pesquisas e por possuírem características favoráveis para o processamento, conforme resultados obtidos em testes preliminares.

As amostras foram levadas ao laboratório no mesmo dia da colheita e refrigeradas e, todo material foi processado dentro do período máximo de 48 horas, após seu recebimento.

Os frutos processados apresentavam ótimas condições para consumo "in natura" e estavam no seu ponto ótimo de maturação, quando tinham, portanto, as melhores características sensoriais, físicas e químicas.

\subsection{Caracterização da matéria-prima}

\subsubsection{Análises físicas}

a) Textura do fruto: $\mathrm{Na}$ determinação da textura dos frutos foi utilizado o "Texture Testing System" modelo TP-1, acoplado a um registrador 
automático de variações de força, operando com célula-padrão de cisalhamento e compressão CS-1, com 10 lâminas de 1/8 polegada de espessura e ângulos de $90^{\circ}$. O instrumento estava provido de um anel de prova de $300 \mathrm{lbf}$ e a velocidade de descida do pistão foi de $20 \mathrm{~cm} / \mathrm{min}$.

As amostras foram anteriormente pesadas (100 $\mathrm{g}$ de morangos inteiros, sem os cálices) e colocadas ao acaso na célula-teste. Os resultados são apresentados em libra força por grama de amostra.

b) Suculência: Para as determinações de suculência dos frutos foi utilizado o "Texture Testing System", empregando a célula-padrão de sucolometria $\mathrm{CR}-1$ (succulometer cell). $\mathrm{O}$ instrumento estava provido de um anel de $3000 \mathrm{lbf}$ e a velocidade de descida do pistão foi de $20 \mathrm{~cm} / \mathrm{min}$.

As amostras foram previamente pesadas $(80 \mathrm{~g}$ de morangos inteiros, sem os cálices) e colocadas ao acaso na célula-teste, sendo o volume de suco liberado coletado em proveta graduada de $50 \mathrm{ml}$. Os dados apresentados correspondem ao volume de suco liberado (ml) por grama de amostra, quando submetida a uma força máxima de compressão, pelo tempo de dois minutos.

c) Rendimento: Para as determinações de rendimento da matériaprima, foram utilizadas amostras de $1000 \mathrm{~g}$ de frutos tomados aleatoriamente dos lotes do material.

Inicialmente, os morangos foram pesados em balança semi-analítica conforme eram recebidos no laboratório, sendo, a seguir, limpos, lavados e drenados por 15 minutos e, então, novamente pesados. Os resultados são apresentados em porcentagem do peso da matéria-prima pronta para processamento em relação ao peso original da matéria-prima. 
Todas as determinações fisicas foram efetuadas com três repetições em amostras tomadas aleatoriamente dos lotes das duas variedades da matéria-prima.

\subsubsection{Análises químicas}

a) pH: Foi determinado em potenciômetro Alphalab, modelo PA200. Os resultados são expressos em unidades de $\mathrm{pH}$.

b) Acidez total titulável: Foi determinada segundo método de referência número 22060 da "ASSOCIATION OF OFFICIAL ANALYTICAL CHEMISTS" - AOAC (1975), conforme descrito a seguir.

Amostras de $10 \mathrm{~g}$ foram trituradas com $90 \mathrm{ml}$ de água destilada e, a seguir, tituladas rapidamente e sob agitação, com solução $0,1 \mathrm{~N}$ de $\mathrm{NaOH}$, até pH $=7,0$; a partir deste ponto a titulação prosseguiu lentamente até $\mathrm{pH}=8,1$. Os resultados são expressos em porcentagem do ácido presente em maior quantidade na matéria-prima, que no caso do morango, é o ácido citrico.

c) Teor de sólidos solúveis: Expresso em graus $\left({ }^{\circ}\right)$ Brix - foi determinado em refratômetro Atago, modelo $\mathrm{N}-1$. Resultados expressos em porcentagem (massa/massa).

d) Ácido ascórbico: Foi determinado por extração em ácido oxálico e titulação, segundo método de Tillmans modificado por LEME JÚNIOR \& MALAVOLTA (1950).

Amostras de 10 gramas foram trituradas em liquidificador com $50 \mathrm{ml}$ de ácido oxálico a 4:1000, durante três minutos. A seguir a mistura foi passada para um balão volumétrico de $100 \mathrm{ml}$. O copo de liquidificador foi lavado com porções de $20 \mathrm{ml}$ de ácido oxálico, que eram adicionadas ao balão volumétrico 
de $100 \mathrm{ml}$, até completar o volume. $\mathrm{O}$ conteúdo do balão foi filtrado e $2 \mathrm{ml}$ deste foram pipetado para um erlenmeyer de $125 \mathrm{ml}$ e adicionado $50 \mathrm{ml}$ de água destilada, que a seguir foi titulado sob agitação, com solução corante de 2,6 diclorofenolindofenol. Os teores de vitamina $C$ das amostras foram calculados tomando-se por base um padrão de vitamina $\mathrm{C}$, previamente determinado. Os resultados foram expressos em $\mathrm{mg}$ de vitamina $\mathrm{C}$ por $100 \mathrm{~g}$ de amostra.

Todas as análises químicas foram efetuadas com três repetições em amostras tomadas aleatoriamente dos lotes das duas variedades da matériaprima.

\subsection{Processamento}

As operações que foram utilizadas no processamento dos morangos estão indicadas na Figura 1.

Após o recebimento dos lotes de morango no laboratório, os frutos eram imediatamente selecionados, e os cálices removidos e em seguida lavados e drenados por cerca de 15 minutos. Cada lote de matéria-prima foi dividido em porções equivalentes, às quais foram aplicados os tratamentos esquematizados na Figura 2.

\subsubsection{Tratamentos de pré-processamento}

Cada variedade de morango foi submetida aos seguintes tratamentos: 


\section{RECEBIMENTO DA MATÉRIA-PRIMA}

$\downarrow$

SELEÇÃO DA MATÉRIA-PRIMA

$\downarrow$

REMOÇÃO DOS CÁLICES (MANUALMENTE)

$\downarrow$

LAVAGEM

COM ÁGUA A TEMPERATURA AMBIENTE

$\downarrow$

DRENAGEM DA ÁGUA

$\downarrow$

$\downarrow \rightarrow$ RETIRADA DE AMOSTRAS PARA

ANÁLISES

$\downarrow$

TRATAMENTOS DE PRÉ-PROCESSAMENTO

$\downarrow$

ACONDICIONAMENTO

$\downarrow$

EXAUSTÃO $\left(85^{\circ} \mathrm{C}\right)$

$\downarrow$

RECRAVAÇÃO

$\downarrow$

ESTERILIZAÇÃO

$\downarrow$

RESFRIAMENTO

$\downarrow$

ARMAZENAMENTO À TEMPERATURA AMBIENTE

Figura 1. Fluxograma das operações utilizadas no processamento dos morangos. 


\begin{tabular}{|c|c|c|c|c|c|c|}
\hline \multicolumn{3}{|c|}{ SEM ADIÇÃO DE CORANTE (A) } & \multicolumn{4}{|c|}{ COM ADIÇÃO DE CORANTES (B) } \\
\hline 1 & 2 & 3 & 4 & 5 & 6 & 7 \\
\hline MORANGO & MORANGO & MORANGO & MORANGO & MORANGO & MORANGO & MORANGO \\
\hline+ & + & + & + & + & + & + \\
\hline \multirow[t]{7}{*}{ SACAROSE } & SACAROSE & SACAROSE & SACAROSE & SACAROSE & SACAROSE & SACAROSE \\
\hline & + & + & + & + & + & + \\
\hline & PECTINA & PECTINA & SUCO DE & PECTINA & PECTINA & VITAMINA \\
\hline & & + & MORANGO & + & + & C \\
\hline & & $\mathrm{CaCl}_{2}$ & & SUCO DE & $\mathrm{CaCl}_{2}$ & + \\
\hline & & & & AMORA & + & SUCO DE \\
\hline & & & & & CORANTE & MORANGO \\
\hline
\end{tabular}

Figura 2 - Esquema dos tratamentos de pré-processamento aos quais os morangos de cada variedade foram submetidos.

\section{A. Tratamentos sem aplicação de corantes}

\section{Morango + Sacarose}

Depois de lavados, drenados e pesados, os frutos foram furados (Figura 3) e colocados em um tacho (em banho-maria). Em seguida, adicionou-se sacarose na proporção de 4:1 em relação ao peso dos frutos e água na proporção de 2:1 em relação ao peso da sacarose. Os morangos foram aquecidos até atingirem $80^{\circ} \mathrm{C}$, após o que foram rapidamente enlatados e levados para a exaustão (até atingirem $85^{\circ} \mathrm{C}$ ). Em seguida, as latas foram recravadas e o produto esterilizado a $97^{\circ} \mathrm{C}$ (água em ebulição) por cinco minutos, sendo, as latas, posteriormente resfriadas e armazenadas à temperatura ambiente.

\section{Morango + Sacarose + Pectina}

Este tratamento seguiu o mesmo procedimento que o anterior (A.1.), porém, com adição de $0,2 \%$ de pectina em relação ao peso dos frutos. A pectina, 
antes de ser adicionada ao produto foi misturada a $50 \mathrm{~g}$ de açúcar para evitar a formação de grumos.

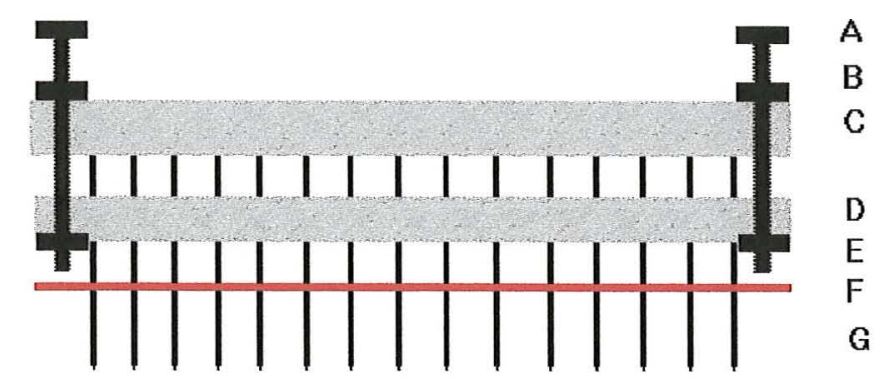
A: Parafuso de sustentação
B: Porca de regulagem
C: Placa suporte (madeira)
D: Placa de regulagem da altura (madeira)
E: Porca de regulagem
F: Placa extratora
G: Agulhas perfuradoras (aço inoxidável)

Figura 3 - Representação esquemática do aparelho utilizado na perfuração dos morangos.

\section{Morango + Sacarose + Pectina $+\mathrm{CaCl}_{2}$}

Este tratamento seguiu o mesmo procedimento que o anterior (A.2.), porém, com a adição de cloreto de cálcio na proporção de $0,2 \%$ em relação ao peso dos frutos. O cloreto foi dissolvido em um pouco de água antes de ser adicionado ao produto. 


\section{B. Tratamentos com aplicação de corantes}

\section{Morango + Sacarose + Suco de morango}

Após lavados, drenados, pesados e furados, os frutos foram misturados com suco do próprio morango (extraído em despolpadeira BONINA $0,25 \mathrm{df}$, utilizando as peneiras de 1,0 e $0,6 \mathrm{~mm}$ ) na proporção de 2:1 em relação ao peso da sacarose que foi previamente adicionada ao produto na proporção de $4: 1 \mathrm{em}$ relação ao peso dos frutos. Os morangos foram aquecidos a $80^{\circ} \mathrm{C} \mathrm{e}$ imediatamente enlatados, seguindo para a exaustão a $85^{\circ} \mathrm{C}$, recravação e esterilizados por cinco minutos, a $97^{\circ} \mathrm{C}$ (água em ebulição).

\section{Morango + Sacarose + Pectina + Suco de amora}

Este tratamento seguiu o mesmo procedimento que 0 anterior (B.4.), porém, com adição de $0,2 \%$ de pectina e substituindo o suco de morango por suco de amora. O suco de amora foi extraído em despolpadeira BONINA $0,25 \mathrm{df}$, utilizando as peneiras de 1,0 e 0,6 mm.

\section{Morango + Sacarose + Pectina $+\mathrm{CaCl}_{2}+$ Corante}

Este tratamento seguiu o mesmo procedimento do tratamento (A.3.), porém, com a adição de corante. Os corantes utilizados foram: Carmim de Cochonilha (corante natural) e, Sicivit Amaranto 85 E 123 (corante artificial) na proporção de $9: 1$, respectivamente. Seguiu-se, de acordo com a legislação, o limite máximo de emprego de corantes artificiais $(0,01 \%)$.

\section{Morango + Sacarose + Suco de morango + Vitamina C}

Este tratamento seguiu o mesmo procedimento do tratamento (B.4.), porém com a adição de ácido ascórbico (vitamina $\mathrm{C}$ ). $\mathrm{O}$ ácido ascórbico foi usado, conforme a legislação, na proporção de $300 \mathrm{mg} / \mathrm{kg}$ de fruto. 


\subsubsection{Acondicionamento}

O acondicionamento foi feito em latas metálicas de folha-deflandres, com capacidade de $450 \mathrm{~g}(74,6 \times 95,2 \mathrm{~mm})$, revestidas internamente com verniz epóxi, próprias para produtos ácidos. Em cada lata foram colocados cerca de 200 gramas de morango, preenchendo o volume do recipiente com o xarope correspondente a cada tratamento.

\subsubsection{Exaustão e recravação}

Foi feita a exaustão em banho-maria, até que o centro geométrico dos recipientes atingisse $85^{\circ} \mathrm{C}$. A seguir as latas foram imediatamente recravadas.

\subsubsection{Esterilização e resfriamento}

A esterilização foi feita por imersão das latas em água fervente $\left(97^{\circ} \mathrm{C}\right)$ durante cinco minutos e a seguir resfriadas em tanque com circulação de água fria.

\subsubsection{Armazenamento}

Uma vez resfriadas, as latas foram armazenadas à temperatura ambiente. 


\subsection{Avaliação do produto processado}

Para avaliar a qualidade dos morangos termicamente processados, assim como determinar qual variedade melhor se adaptou ao processamento e a eficiência dos tratamentos, foram realizadas análises físicas, quimicas e sensorial.

\subsubsection{Análises físicas}

a) Textura - para as determinações da textura dos frutos foi utilizado o "Texture Testing System", conforme descrito no item 4.2.1.a.

b) Suculência - para as determinações de suculência dos frutos foi utilizado o "Texture Testing System", conforme descrito no item 4.2.1.b.

c) Vácuo: foi determinado o vácuo das latas com o auxílio do Vacuômetro "Marshalltow", em polegadas de mercúrio (pol. Hg).

d) Peso bruto: foi utilizada uma balança semi-analítica para a determinação do peso total (embalagem mais o produto).

e) Peso drenado: foi determinado com um conjunto constituído de peneira US-Tyler $n^{\circ} 8$ (abertura da malha de $2,38 \mathrm{~mm}$ ) e fundo. Todo conteúdo da lata foi invertido no conjunto peneira-fundo, inclinando-se ligeiramente a peneira (ângulo de $45^{\circ}$ ) sobre 0 fundo e deixando-se drenar durante dois minutos. O peso da peneira mais o peso do produto menos o peso da peneira, constitui o peso drenado.

f) Peso líquido: peso bruto descontado do peso da lata vazia, limpa e seca, utilizando balança semi-analítica (com precisão de $0,01 \mathrm{~g}$ ). 
Todas as determinações fisicas realizadas no produto final foram efetuadas com três repetições em amostras tomadas aleatoriamente, dos lotes de produto processado das variedades em estudo.

\subsubsection{Análises químicas}

Para a caracterização química do produto final, foram retiradas amostras do produto que consistiam em parte sólida (frutos) e parte líquida (calda), de cada um dos sete tratamentos, aos quais foi submetida a matériaprima. Nestas amostras foram efetuadas as seguintes análises:

a) $\mathrm{pH}$ : conforme descrito no item 4.2.2.a.

b) Acidez total titulável: conforme descrito no item 4.2.2.b.

c) Sólidos solúveis: conforme descrito no item 4.2.2.c.

d) Ácido ascórbico: conforme descrito no item 4.2.2.d.

Todas as determinações quimicas realizadas no produto final foram efetuadas com três repetições em amostras tomadas aleatoriamente, dos lotes de produto processado das variedades em estudo.

\subsubsection{Análise sensorial}

As amostras dos lotes das duas variedades de morango estudadas foram avaliadas subjetivamente quanto à cor, textura e sabor.

As avaliações das amostras foram realizadas por uma equipe de 14 provadores, previamente selecionada e treinada para este tipo de avaliação, utilizando uma escala hedônica estruturada de nove pontos (GIRARDOT et al., 1952; DAWSON, 1964; MARTIN, 1973). Atributos de qualidade como cor, textura 
e sabor (notadamente este último), devido à complexidade inerente aos mesmos, são geralmente avaliados de maneira mais adequada pela análise sensorial (SAWYER, 1971). Os modelos de fichas utilizados nestas avaliações estão apresentados nas Figuras 4,5 e 6.

Para avaliação da cor dos frutos, as amostras foram servidas em pratos de louça branca, duas vezes em sessões diferentes, os quais foram dispostos aleatoriamente em bandeja de plástico branco, colocada em local com iluminação de luz fluorescente. Os pratos foram codificados com números aleatórios compostos de três dígitos.

Para avaliação da textura e do sabor, cada amostra foi servida aos provadores (duas vezes em seções diferentes) em pratos de plástico branco, codificada com números aleatórios de três dígitos e em cabines individuais iluminadas com luz vermelha, para mascarar a cor dos frutos.

\subsubsection{Análise estatística dos resultados}

\section{a) Matéria-prima}

Os dados da matéria-prima foram apresentados através de médias com os respectivos erros padrão da média, correspondente a três repetições.

\section{b) Produto}

Os dados do produto processado foram analisados através do delineamento em blocos casualizados (DBC) com sete tratamentos e cinco repetições para cada variedade testada, com utilização do teste de Tukey (5\%) (GOMES, 1973a; BANZATTO \& KRONKA, 1995). 
Todas as médias possuíam o mesmo número de repetições; os tratamentos foram designados às parcelas de forma casual, sendo essa casualização feita dentro de cada bloco (épocas de avaliação) (BANZATTO \& KRONKA, 1995).

As médias obtidas na avaliação sensorial foram analisadas através do DBC com sete tratamentos e quatorze repetições para cada variedade testada, com utilização do teste de Tukey $(5 \%)$. Cada provador foi designado como sendo um bloco.

\section{AVALIAÇÃO SENSORIAL}

Produto: MORANGO EM CALDA

Nome: Data:

Por favor, prove as amostras e indique a intensidade da TEXTURA de acordo com a escala abaixo:

\begin{tabular}{|c|c|c|c|c|c|}
\hline AMOSTRAS & MUITO MOLE & MOLE & NEM MOLE NEM FIRME & FIRME & MUITO FIRME \\
\hline & & & $\begin{array}{lll}4 & 5 & 6 \\
\end{array}$ & & \\
\hline & & & & & \\
\hline & & & & & \\
\hline & & & & & \\
\hline
\end{tabular}

Comentários:

Figura 4. Modelo de ficha utilizada na avaliação sensorial das amostras quanto à textura. 


\section{AVALIAÇÃO SENSORIAL}

Produto: MORANGO EM CALDA

Nome: Data:

Por favor, prove as amostras e indique a intensidade do SABOR de acordo com a escala abaixo:

\begin{tabular}{|l|c|cc|ccc|cc|c|}
\hline AMOSTRAS & SEM SABOR & \multicolumn{2}{|c|}{ SABOR FRACO } & \multicolumn{2}{|c|}{ SABOR MODERADO } & \multicolumn{2}{|c|}{ SABOR INTENSO } & SABOR MUITO INTENSO \\
& 1 & 2 & 3 & 4 & 5 & 6 & 7 & 8 & 9 \\
\hline & & & & & & & & \\
\hline & & & & & & & \\
\hline & & & & & & & & \\
\hline
\end{tabular}

Comentários:

Figura 5. Modelo de ficha utilizada na avaliação sensorial das amostras quanto ao sabor.

\section{AVALIAÇÃO SENSORIAL}

Produto: MORANGO EM CALDA

Nome:

Data: _ I I

Por favor, observe as amostras e indique a intensidade da COR de acordo com a escala abaixo:

\begin{tabular}{|c|c|c|c|c|c|}
\hline AMOSTRAS & SEMCOR & COR FRACA & COR MODERADA & COR INTENSA & COR MUITO INTENSA \\
\hline & 1 & 23 & $\begin{array}{lll}4 & 5 & 6\end{array}$ & & \\
\hline & & & & & \\
\hline & & & & & \\
\hline & & & & & \\
\hline
\end{tabular}

Comentários:

Figura 6. Modelo de ficha utilizada na avaliação sensorial das amostras quanto à cor. 


\section{RESULTADOS E DISCUSSÃO}

Testes preliminares demonstraram que as variedades utilizadas neste trabalho mostraram-se de qualidades organolépticas superiores às variedades usadas por empresas que fabricam o morango em calda.

\subsection{Caracterização da matéria prima}

\subsubsection{Análises físicas}

Na Tabela 1, são apresentados os resultados da avaliação objetiva dos atributos físicos (rendimento, textura e suculência).

Tabela 1. Características físicas das variedades de morango "in natura" (matériaprima).

\begin{tabular}{l|c|c}
\hline & \multicolumn{2}{c}{ MÉDIA DAS ANÁLISES (3 repetições) } \\
\hline \multicolumn{1}{c}{ ANÁLISES } & Variedade Chandler & Variedade Reiko \\
\hline Textura (lbf/g) & $0,89 \pm 0,04$ & $0,58 \pm 0,010$ \\
Suculência (ml/g) & $0,44 \pm 0,01$ & $0,52 \pm 0,014$ \\
Rendimento (\%) & 95,8 & 96,8 \\
\hline
\end{tabular}

A variedade Reiko apresentou uma maior suculência $(0,52)$ e uma menor textura $(0,58)$ quando comparada com a variedade Chandler, que apresentou 0,44 e 0,89 , respectivamente. Os rendimentos das duas variedades estudadas mostram que para cada $1000 \mathrm{~g}$ de morango "in natura" $958 \mathrm{~g}$ da 
Chandler e $968 \mathrm{~g}$ da Reiko foram utilizados para o processamento, o que demonstra um alto aproveitamento e boa qualidade da matéria-prima, com ausência de frutos amassados, machucados ou deteriorados por microrganismos.

De acordo com PASCHOALINO et al. (1973/74), variações na cultura e manuseio do fruto estão relacionadas com a firmeza da fruta. Pectinas solúveis aumentam com a demora da colheita e estocagem pós-colheita (ESKIN, 1991). De acordo com BOURNE (1982), a firmeza é um fator importante na qualidade e muitas frutas são geralmente colhidas a um dado nível de firmeza que é usada para estabilizar um grau de qualidade e preço. Frutas estocadas sob refrigeração por várias horas geralmente apresentam um grau de firmeza maior do que quando estocadas à temperatura de campo. Com poucas exceções, a firmeza diminui com o aumento da temperatura.

Segundo HUDSON et al. (1975a), a suculência é um atributo físico dos frutos frescos inversamente proporcional à textura destes, isto é, quanto mais firme, menos suculento ele será. Esta afirmação está de acordo com os resultados encontrados.

\subsubsection{Análises químicas}

Os resultados das determinações do teor de vitamina $\mathrm{C}, \mathrm{pH}$, acidez total titulável e do teor de sólidos solúveis (Brix) da matéria-prima estão apresentados na Tabela 2.

Os teores de vitamina $C$ relativos às duas variedades estudadas Chandler (119,32 mg/100 g) e Reiko (125,05 mg/100 g), estão de acordo com BERBARI (1992) que estudou as variedades IAC - Princesa Izabel, Reiko, Sequóia e Chandler e encontrou os valores 148, 162, 177 e 152 mg/100 g, respectivamente. 
Tabela 2. Características químicas das variedades de morango "in natura" (matéria-prima).

\begin{tabular}{l|c|c}
\hline & \multicolumn{2}{c}{ MÉDIA DAS ANÁLISES (3 repetições) } \\
\hline \multicolumn{1}{c|}{ ANÁLISES } & Variedade Chandler & Variedade Reiko \\
\hline Teor de vitamina C (mg/100g) & $119,32 \pm 6,17$ & $125,05 \pm 4,67$ \\
$\mathrm{pH}$ & $3,41 \pm 0,01$ & $3,50 \pm 0,01$ \\
Acidez total titulável (\%) & $0,77 \pm 0,04$ & $0,83 \pm 0,01$ \\
Sólidos solúveis (Brix) & $8,21 \pm 0,01$ & $9,94 \pm 0,04$ \\
\hline
\end{tabular}

Estes resultados mostraram-se altos quando comparados com os dados obtidos por PASCHOALINO et al. (1973/74), estudando 12 variedades, encontraram um intervalo de valores entre 24 e $64 \mathrm{mg} / 100 \mathrm{~g}$; GARROTE \& BERTONE (1976) estudando 11 variedades diferentes, encontraram valores entre 49,17 e 92,55 mg/100 g; SELVARAJ et al. (1976) para 20 variedades diferentes de morango encontraram valores entre 29,2 e 89,1 mg/100 g; PASCHOALINO (1977), que constatou $46,0 \mathrm{mg} / 100 \mathrm{~g}$ para variedades IAC 2712; FUSTER et al. (1982) estudando as variedades Tioga, Tuff, Tioga Salamanca e Cambridge encontraram 40,89, 93,13, 68,92 e 78,46 mg/100 g, respectivamente; GUEGOV et al. (1982) estudando 12 variedades diferentes de morango encontraram valores entre 19,9 e $48,7 \mathrm{mg} / 100 \mathrm{~g}$ e FIK \& MACURA (1986), que encontraram $33,2 \mathrm{mg} / 100 \mathrm{~g}$.

Comparando as duas variedades (Tabela 2), verifica-se que a variedade Reiko apresentou um teor de vitamina $\mathrm{C}$ mais elevado que a variedade Chandler, 125,05 e 119,32 mg/100 g, respectivamente.

Os valores de $\mathrm{pH}$ obtidos foram, em geral, semelhantes aos encontrados por PASCHOALINO et al. (1973/74), que encontraram valores entre 3,20 e 3,45; GARROTE \& BERTONE (1976) encontraram valores entre 3,14 e 3,84; PASCHOALINO (1977) encontrou o valor de 3,60 para a variedade IAC2712; GHERARDI et al. (1983) estudando 19 variedades de morangos de 
diferentes origens (16 variedades de regiões da Itália, duas da Polônia e uma da luguslávia), encontraram um intervalo de valores entre 3,30 e 3,78 e BERBARI (1992), 3,39 e 3,62 para as variedades Chandler e Reiko, respectivamente. Acidez e pH são fatores de extrema importância na aceitação de um produto, pois um produto excessivamente ácido não é possivel de ser consumido, principalmente no mercado nacional, cujo hábito é de produtos pouco ácidos (ALBREGTS \& HOWARD, 1978). As variedades estudadas apresentaram valores de acidez menores que os encontrados por GARROTE \& BERTONE (1976) e BERBARI (1992).

O teor de sólidos solúveis (Brix) é um importante parâmetro, pois fornece a concentração de açúcares contidos na fruta.

As variedades estudadas apresentaram valores de sólidos solúveis (Brix) variando de 8 (Chandler) a 10\% (Reiko). Os resultados obtidos estão de acordo com os valores médios citados por PASCHOALINO et al. (1973/74), que encontraram valores entre 5,6 e 9,1\%; GARROTE \& BERTONE (1976), para 11 variedades, com valores entre 6,55 e 15,64\%; SELVARAJ et al. (1976), para 20 variedades americanas, com valores de sólidos solúveis variando entre 3,06 e $12,04 \%$ e PASCHOALINO (1977) encontrou $6,02 \%$.

Observa-se (Tabela 2) que a variedade Reiko apresentou um teor médio de sólidos solúveis maior que a variedade Chandler, 9,94 e 8,21, respectivamente.

\subsection{Caracterização do produto final}

\subsubsection{Análises físicas}

As análises físicas efetuadas, envolvendo determinações do peso bruto das latas, peso drenado e peso líquido, nos períodos de 0 a 180 dias de 
armazenamento, à temperatura ambiente, mostraram resultados normais, sem variações significativas (Tabelas 3, 4 e 5).

Nas Tabelas 6 e 7 são apresentados os resultados da avaliação objetiva da suculência e da textura dos morangos processados das variedades em estudo.

A firmeza e maturidade dos genótipos têm influência direta nas características do morango. Fruta mais madura e uma demora na colheita aumentam a porcentagem de fatias mais moles. Os mais importantes atributos de qualidade em morangos processados são a textura e a cor (ESKIN, 1991). O processamento pode afetar significativamente a firmeza dos morangos, uma vez que esta depende de vários constituintes e de suas modificações no produto (SLAUGHTER et al., 1983; ESKIN, 1991).

A variedade Chandler mostrou-se menos suculenta e com maior firmeza que a variedade Reiko (Tabelas 6 e 7, respectivamente). Para a variedade Chandler, observou-se que os tratamentos não diferiram entre si quanto à suculência, enquanto que para a variedade Reiko o tratamento 2 diferiu dos tratamentos 4 e 5 e, os demais tratamentos não diferiram entre si (Figuras 7 e 8).

Com relação à textura, a variedade Chandler apresentou-se melhor que a variedade Reiko (Tabela 4). Observa-se que para a variedade Chandler o tratamento 6 não diferiu do 3, porém, ambos diferiram dos demais tratamentos. Para a variedade Reiko os tratamentos 3 e 6 diferiram entre si e dos demais tratamentos. Periodos de avaliação consecutivos não diferiram entre si para a variedade Chandler.

Verifica-se que o tratamento 6 (morango + sacarose + pectina + cloreto de cálcio + corante) apresentou-se melhor em termos de textura dos frutos. Este fato pode ser explicado pela interação pectina/cálcio, originando 
Tabela 3. Peso bruto (g) dos morangos termicamente processados.

\begin{tabular}{|c|c|c|c|c|c|c|c|c|c|c|c|c|}
\hline & & & & PESO BRI & UTO ( ME & IA DAS A & ÁLISES) & & & & & \\
\hline & & & Chandler & & & & & & Reiko & & & \\
\hline TRATAMENTOS & $45^{\circ} \mathrm{DIA}$ & $90^{\circ} \mathrm{DIA}$ & $120^{\circ} \mathrm{DIA}$ & $150^{\circ} \mathrm{DIA}$ & $180^{\circ} \mathrm{DIA}$ & MEEDIA & $45^{\circ} \mathrm{DIA}$ & $90^{\circ} \mathrm{DIA}$ & $120^{\circ} \mathrm{DIA}$ & $150^{\circ} \mathrm{DIA}$ & $180^{\circ} \mathrm{DIA}$ & MEEDIA \\
\hline 1 & 400,360 & 406,860 & 420,570 & 422,160 & 371,440 & $404,278^{\mathrm{A}}$ & 417,780 & 410,410 & 420,150 & 428,820 & 422,450 & $419,922^{\mathrm{A}}$ \\
\hline 2 & 412,370 & 421,060 & 418,120 & 423,880 & 424,490 & $419,984^{\mathrm{A}}$ & 425,430 & 421,090 & 420,610 & 422,530 & 421,590 & $422,250^{\mathrm{A}}$ \\
\hline 3 & 418,620 & 412,500 & 423,960 & 410,020 & 408,170 & $414,654^{\mathrm{A}}$ & 413,710 & 405,890 & 416,830 & 414,900 & 413,540 & $412,974^{\mathrm{A}}$ \\
\hline 4 & 396,510 & 413,900 & 406,950 & 407,310 & 410,860 & $407,106^{\mathrm{A}}$ & 428,090 & 373,250 & 420,350 & 422,070 & 416,410 & $412,034^{\mathrm{A}}$ \\
\hline 5 & 423,800 & 418,500 & 422,860 & 419,330 & 428,610 & $422,620^{A}$ & 418,600 & 427,210 & 419,440 & 413,440 & 416,530 & $419,044^{\mathrm{A}}$ \\
\hline 6 & 440,110 & 415,340 & 413,570 & 415,210 & 411,250 & $419,096^{\mathrm{A}}$ & 410,400 & 425,720 & 415,370 & 426,970 & 425,880 & $420,868^{\mathrm{A}}$ \\
\hline 7 & 421,080 & 422,050 & 417,450 & 424,650 & 419,710 & $420,988^{\mathrm{A}}$ & 418,100 & 420,800 & 426,940 & 418,560 & 422,870 & $421,454^{\mathrm{A}}$ \\
\hline ÉPOCAS DE AVAL. & $416,121^{\text {a }}$ & $415,744^{\mathrm{a}}$ & $417,640^{\text {a }}$ & $417,509^{\mathrm{a}}$ & $410,647^{\mathrm{a}}$ & & $419,873^{a}$ & $412,053^{a}$ & $419,956^{a}$ & $421,041^{\mathrm{a}}$ & $419,896^{a}$ & \\
\hline $\mathrm{F}$ (Tratamentos) & & & 0,54 n.s. & & & & & & $0,92 \mathrm{n}$ & a.s. & & \\
\hline F (Épocas de aval.) & & & 2,43 n.s. & & & & & & $0,98 \mathrm{n}$ & & & \\
\hline
\end{tabular}

Para cada variedade, médias de tratamento (épocas de avaliação) seguidos de mesma letra maiúscula (minúscula) não diferem entre si, pelo teste de Tukey, ao nível de $5 \%$ de probabilidade.

Tabela 4. Peso drenado (g) dos morangos termicamente processados.

\begin{tabular}{|c|c|c|c|c|c|c|c|c|c|c|c|c|}
\hline \multirow{2}{*}{\multicolumn{13}{|c|}{ PESO DRENADO ( MÉDIA DAS ANÁLISES) }} \\
\hline \multicolumn{6}{|c|}{$\begin{array}{l}\text { PESO DRENADO ( MEDIA DAS ANÁLISES) } \\
\text { Chandler }\end{array}$} & & & & & & & Reiko \\
\hline TRATAMENTOS & $45^{\circ} \mathrm{DIA}$ & $90^{\circ} \mathrm{DIA}$ & $120^{\circ} \mathrm{DIA}$ & $150^{\circ} \mathrm{DIA}$ & $180^{\circ} \mathrm{DIA}$ & MÉDIA & $45^{\circ} \mathrm{DIA}$ & $90^{\circ} \mathrm{DIA}$ & $120^{\circ} \mathrm{DIA}$ & $150^{\circ} \mathrm{DIA}$ & $180^{\circ} \mathrm{DIA}$ & MÉDIA \\
\hline 1 & 202,300 & 212,750 & 182,600 & 196,300 & 209,350 & $200,660^{A}$ & 184,550 & 188,300 & 192,500 & 192,500 & 198,700 & $191,310^{A}$ \\
\hline 2 & 230,400 & 210,800 & 211,700 & 207,100 & 225,050 & $217,010^{\mathrm{A}}$ & 185,200 & 174,850 & 188,950 & 191,250 & 113,250 & $170,700^{\mathrm{A}}$ \\
\hline 3 & 208,050 & 207,100 & 212,900 & 195,200 & 187,050 & $202,060^{\mathrm{A}}$ & 178,550 & 194,650 & 193,250 & 190,150 & 205,690 & $192,458^{A}$ \\
\hline 4 & 214,350 & 210,200 & 202,700 & 191,270 & 204,100 & $204,524^{\mathrm{A}}$ & 183,900 & 169,450 & 182,650 & 176,000 & 189,450 & $180,290^{\mathrm{A}}$ \\
\hline 5 & 216,400 & 213,850 & 214,050 & 206,500 & 206,850 & $211,530^{\mathrm{A}}$ & 192,450 & 191,000 & 201,750 & 201,950 & 188 & $195,130^{\mathrm{A}}$ \\
\hline 6 & 197,250 & 192,300 & 196,750 & 186,100 & 200,200 & $194,520^{\mathrm{A}}$ & 180,200 & 185,450 & 197,200 & 185,550 & 184,400 & $186,560^{\mathrm{A}}$ \\
\hline 7 & 214,700 & 208,150 & 212,950 & 210,100 & 199,750 & $209,130^{\mathrm{A}}$ & 190,000 & 199,150 & 199,300 & 192,600 & 187,600 & $193,730^{\mathrm{A}}$ \\
\hline ÉPOCAS DE AVAL. & $211,921^{\mathrm{a}}$ & $207,879^{\mathrm{at}}$ & $204,807^{2}$ & $198,939^{b}$ & $204,621^{\text {ab }}$ & & $184,979^{\mathrm{a}}$ & $186,121^{\mathrm{a}}$ & $193,657^{\mathrm{a}}$ & $190,000^{2}$ & $181,0843^{2}$ & \\
\hline F (Tratamentos) & & & $4,71 * *$ & & & & & & 1,96 & n.s. & & \\
\hline F (Épocas de aval.) & & & 2,71 n.s. & & & & & & 0,81 & n.s. & & \\
\hline
\end{tabular}

n.s. - não significativo a nível de 5\%

* - significativo a nível de $5 \%$

** - significativo a nível de $1 \%$.

Para cada variedade, médias de tratamento (épocas de avaliação) seguidos de mesma letra maiúscula (minúscula) não diferem entre si, pelo teste de Tukey, ao nível de $5 \%$ de probabilidade. 
Tabela 5. Peso líquido (g) dos morangos termicamente processados.

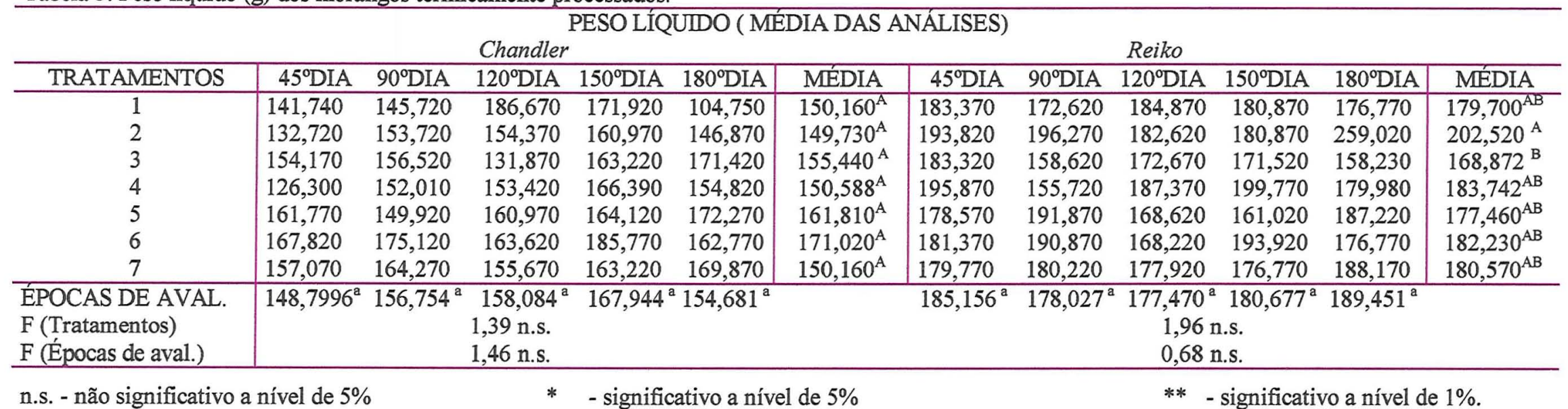

Para cada variedade, médias de tratamento (épocas de avaliação) seguidos de mesma letra maiúscula (minúscula) não diferem entre si, pelo teste de Tukey, ao nível de $5 \%$ de probabilidade.

Tabela 6. Suculência (ml suco/g amostra) dos morangos termicamente processados

\begin{tabular}{|c|c|c|c|c|c|c|c|c|c|c|c|c|}
\hline \multicolumn{13}{|c|}{ SUCULÊNCIA ( MÉDIA DAS ANÁLISES) } \\
\hline \multicolumn{9}{|c|}{ (20) } & \multicolumn{4}{|l|}{ Reiko } \\
\hline TRATAMENTOS & $45^{\circ} \mathrm{DIA}$ & $90^{\circ} \mathrm{DIA}$ & $120^{\circ} \mathrm{DIA}$ & $150^{\circ} \mathrm{DIA}$ & $180^{\circ} \mathrm{DIA}$ & MÉDIA & $45^{\circ} \mathrm{DIA}$ & $90^{\circ} \mathrm{DIA}$ & $120^{\circ} \mathrm{DIA}$ & $150^{\circ} \mathrm{DIA}$ & $180^{\circ} \mathrm{DIA}$ & MÉDIA \\
\hline 1 & 0,2238 & 0,2066 & 0,2206 & 0,2226 & 0,2161 & $0,2179^{\mathrm{A}}$ & 0,2954 & 0,2586 & 0,3298 & 0,2086 & 0,2707 & $0,2726^{A B}$ \\
\hline 2 & 0,1432 & 0,1406 & 0,1237 & 0,2435 & 0,1918 & $0,1686^{\mathrm{A}}$ & 0,1593 & 0,1282 & 0,1783 & 0,2365 & 0,1276 & $0,1660^{\mathrm{B}}$ \\
\hline 3 & 0,1263 & 0,1876 & 0,1311 & 0,2530 & 0,1443 & $0,1685^{\mathrm{A}}$ & 0,3177 & 0,2620 & 0,1880 & 0,2060 & 0,3684 & $0,2684^{A B}$ \\
\hline 4 & 0,2142 & 0,4260 & 0,1741 & 0,2243 & 0,1381 & $0,2353^{\mathrm{A}}$ & 0,2628 & 0,2836 & 0,3381 & 0,2753 & 0,3761 & $0,3072^{A}$ \\
\hline 5 & 0,1714 & 0,1908 & 0,2679 & 0,2702 & 0,2781 & $0,2357^{\mathrm{A}}$ & 0,2612 & 0,3156 & 0,3260 & 0,2798 & 0,2052 & $0,2776^{\mathrm{A}}$ \\
\hline 6 & 0,2645 & 0,3266 & 0,2352 & 0,1245 & 0,2508 & $0,2403^{A}$ & 0,2531 & 0,1930 & 0,2480 & 0,1505 & 0,2693 & $0,2228{ }^{A B}$ \\
\hline 7 & 0,2319 & 0,2855 & 0,2887 & 0,3088 & 0,2845 & $0,2799^{\mathrm{A}}$ & 0,2319 & 0,2908 & 0,2081 & 0,2836 & 0,1923 & $0,2413^{A B}$ \\
\hline ÉPOCAS DE AVAL. & $0,1965^{\mathrm{a}}$ & $0,2520^{\mathrm{a}}$ & $0,2059^{\mathrm{a}}$ & $0,2353^{\mathrm{a}}$ & $0,2148^{a}$ & & $0,2545^{\mathrm{a}}$ & $0,2474^{\mathrm{a}}$ & $0,2595^{\mathrm{a}}$ & $0,2343^{\mathrm{a}}$ & $0,2585^{\mathrm{a}}$ & \\
\hline $\mathrm{F}$ (Tratamentos) & & & 2,13 n.s. & & & & & & 3,53 & & & \\
\hline F (Épocas de aval.) & & & 0,93 n.s. & & & & & & 0,25 & n & & \\
\hline
\end{tabular}

Para cada variedade, médias de tratamento (épocas de avaliação) seguidos de mesma letra maiúscula (minúscula) não diferem entre si, pelo teste de Tukey, ao nível de $5 \%$ de probabilidade. 
Tabela 7. Textura (lbf/g amostra) dos morangos termicamente processados.

\begin{tabular}{|c|c|c|c|c|c|c|c|c|c|c|c|c|}
\hline \multicolumn{13}{|c|}{ TEXTURA ( MÉDIA DAS ANÁLISES) } \\
\hline \multicolumn{9}{|c|}{ 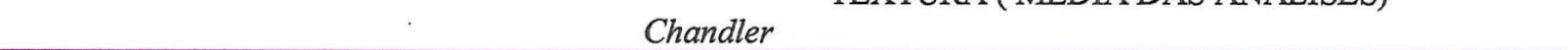 } & \multicolumn{4}{|l|}{ Reiko } \\
\hline TRATAMENTOS & $45^{\circ} \mathrm{DIA}$ & $90^{\circ} \mathrm{DIA}$ & $120^{\circ} \mathrm{DIA}$ & $150^{\circ} \mathrm{DIA}$ & $180^{\circ} \mathrm{DIA}$ & MÉDIA & $45^{\circ} \mathrm{DIA}$ & $90^{\circ} \mathrm{DIA}$ & $120^{\circ} \mathrm{DIA}$ & $150^{\circ} \mathrm{DIA}$ & $180^{\circ} \mathrm{DIA}$ & MÉDIA \\
\hline 1 & 0.5979 & 0,5632 & 0,4328 & 0,4100 & 0.3391 & $0,4686^{\mathrm{B}}$ & 0,5743 & 0,5102 & 0.4941 & 0,4543 & 0.4448 & $0.4955^{\mathrm{CD}}$ \\
\hline 2 & 0,6009 & 0,5381 & 0,5132 & 0,4550 & 0,3842 & $0,4983^{B}$ & 0,6032 & 0,5352 & 0,5150 & 0,4892 & 0,4833 & $0,5252^{\mathrm{c}}$ \\
\hline 3 & 0,6730 & 0,6699 & 0.6744 & 0,5988 & 0.5747 & $0,6382^{\mathrm{A}}$ & 0.6302 & 0,6021 & 0.6003 & 0.5797 & 0.5832 & $0.5991^{\text {в }}$ \\
\hline 4 & 0,6057 & 0,5245 & 0,5102 & 0,4906 & 0,4744 & $0,5211^{\mathrm{B}}$ & 0,5490 & 0,4986 & 0,4489 & 0,4516 & 0,3912 & $0,4679 \mathrm{D}$ \\
\hline 5 & 0,5781 & 0,5258 & 0,4760 & 0,4349 & 0,4290 & $0,4888^{B}$ & 0,5495 & 0,5263 & 0,5341 & 0,5308 & 0,4800 & $0,5241^{\mathrm{C}}$ \\
\hline 6 & 0,7227 & 0,7009 & 0,6825 & 0,6747 & 0,6536 & $0,6869^{\mathrm{A}}$ & 0,6600 & 0,6490 & 0,6471 & 0,6436 & 0,6312 & $0,6464^{A}$ \\
\hline 7 & 0,5162 & 0,4956 & 0,4941 & 0,4445 & 0,4447 & $0,4790^{\mathrm{B}}$ & 0,5072 & 0,5075 & 0,4912 & 0,4450 & 0,4220 & $0,4746^{\mathrm{D}}$ \\
\hline ÉPOCAS DE AVAL. & $0,6135^{\mathrm{a}}$ & $0,5740^{\mathrm{ab}}$ & $0,5405^{b c}$ & $0,5012^{\text {cd }}$ & $0,4714^{\mathrm{d}}$ & & $0,5819^{\mathrm{a}}$ & $0,5470^{b}$ & $0,5330^{b}$ & $0,5135^{\mathrm{bc}}$ & $0,4908^{\circ}$ & \\
\hline $\mathrm{F}$ (Tratamentos) & & & $32,55 * *$ & & & & & & 42,2 & $5 * *$ & & \\
\hline F (Épocas de aval.) & & & $19,51 * *$ & & & & & & 17,1 & $1 * *$ & & \\
\hline
\end{tabular}

Para cada variedade, médias de tratamento (épocas de avaliação) seguidos de mesma letra maiúscula (minúscula) não diferem entre si, pelo teste de Tukey, ao nível de $5 \%$ de probabilidade.

Tabela 8. Vácuo (pol. Hg) dos morangos termicamente processados.

\begin{tabular}{|c|c|c|c|c|c|c|c|c|c|c|c|c|}
\hline \multicolumn{13}{|c|}{ VÁCUO ( MÉDIA DAS ANÁLISES) } \\
\hline \multicolumn{9}{|c|}{ Chandler } & \multicolumn{4}{|l|}{ Reiko } \\
\hline TRATAMENTOS & $45^{\circ} \mathrm{DIA}$ & $90^{\circ} \mathrm{DIA}$ & $120^{\circ} \mathrm{DIA}$ & $150^{\circ} \mathrm{DIA}$ & $180^{\circ} \mathrm{DIA}$ & MEDIA & $45^{\circ} \mathrm{DIA}$ & 90DIA & $120^{\circ} \mathrm{DIA}$ & $150^{\circ} \mathrm{DIA}$ & $180^{\circ} \mathrm{DIA}$ & MEDIA \\
\hline 1 & 11,0 & 8,5 & 13,0 & 8,5 & 12,0 & $10,6^{\mathrm{B}}$ & 10,0 & 10,0 & 11,0 & 11,5 & 12,0 & $10,9^{\mathrm{B}}$ \\
\hline 2 & 10,5 & 9,5 & 11,5 & 12,0 & 11,5 & $11,0^{\mathrm{AB}}$ & 9,0 & 10,0 & 10,5 & 12,5 & 12,0 & $10,8^{\text {B }}$ \\
\hline 3 & 9,0 & 12,0 & 12,5 & 11,0 & 12,5 & $11,4^{\mathrm{AB}}$ & 11,0 & 10,5 & 10,5 & 14,0 & 12,5 & $11,7^{\mathrm{B}}$ \\
\hline 4 & 10,5 & 9,5 & 10,5 & 11,0 & 9,0 & $10,1^{\text {B }}$ & 9,5 & 9,5 & 11,0 & 13,5 & 12,0 & $11,1^{\text {B }}$ \\
\hline 5 & 10,0 & 11,5 & 10,5 & 10,0 & 9,5 & $10,3^{\text {B }}$ & 16,5 & 16,0 & 16,0 & 15,7 & 16,0 & $16,1^{\mathrm{A}}$ \\
\hline 6 & 13,0 & 11,5 & 13,5 & 16,5 & 13,5 & $13,6^{\mathrm{A}}$ & 11,0 & 11,0 & 12,0 & 12,0 & 11,5 & $11,5^{\mathrm{B}}$ \\
\hline 7 & 12,5 & 11,5 & 9,0 & 13,0 & 12,0 & $11,6^{\mathrm{AB}}$ & 10,7 & 12,5 & 11,5 & 13,5 & 13,5 & $12,3^{\text {B }}$ \\
\hline ÉPOCAS DE AVAL. & $10,9^{a}$ & $10,6^{\mathrm{a}}$ & $11,5^{\mathrm{a}}$ & $11,7^{\mathrm{a}}$ & $11,4^{\mathrm{a}}$ & & $11,1^{\mathrm{c}}$ & $11,3^{c}$ & $11,8^{\mathrm{bc}}$ & $13,3^{\mathrm{a}}$ & $12,8^{\mathrm{ab}}$ & \\
\hline F (Tratamentos) & & & $3,27 *$ & & & & & & 27 & $77 * *$ & & \\
\hline $\mathrm{F}$ (Épocas de aval.) & & & 0,71 n.s. & & & & & & & $75 * *$ & & \\
\hline
\end{tabular}

Para cada variedade, médias de tratamento (épocas de avaliação) seguidos de mesma letra maiúscula (minúscula) não diferem entre si, pelo teste de Tukey, ao nível de $5 \%$ de probabilidade. 


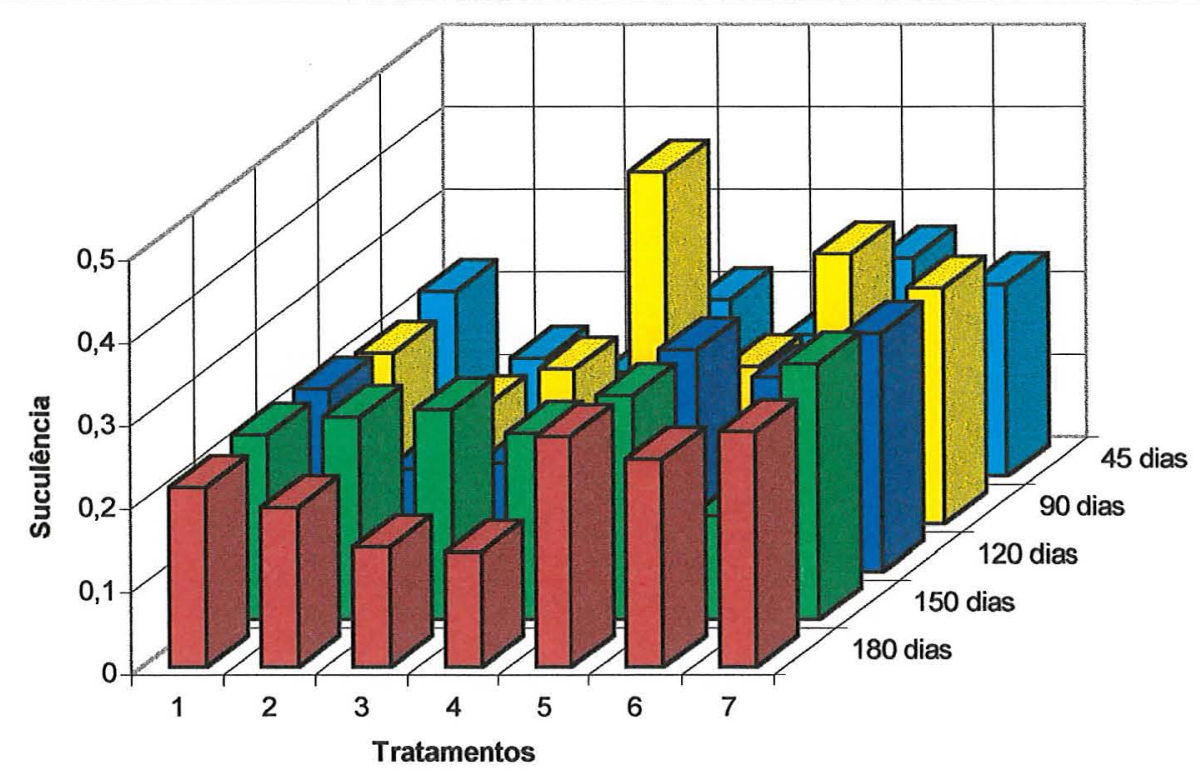

Figura 7. Variação da suculência ( $\mathrm{ml}$ de suco/g de fruto) de acordo com os períodos de armazenamento - Variedade Chandler.

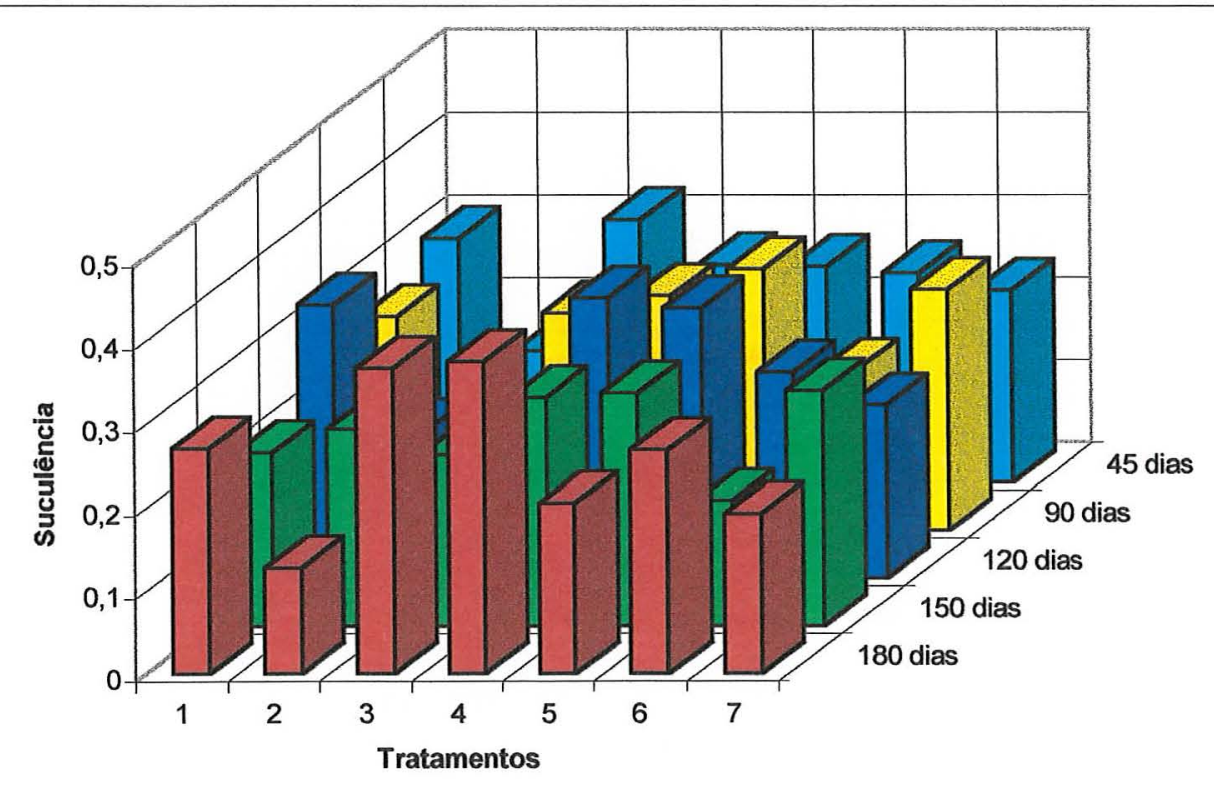

Figura 8. Variação da suculência ( $\mathrm{ml}$ de suco/g de fruto) de acordo com os períodos de armazenamento - Variedade Reiko. 
pectato de cálcio na forma de uma película protetora ao redor dos frutos. Nas avaliações da textura dos frutos os maiores valores obtidos devem-se à resistência que esta película de pectato de cálcio oferece ao cisalhamento dos frutos (MAIN et al., 1986).

Com a utilização de cálcio nota-se um incremento na ação da firmeza, que se deve, provavelmente, ao calor quebrar as ligações químicas nas cadeias poliuronídicas produzindo mais sítios disponiveis para a formação das ligações cruzadas do cálcio na região da lamela média (MORRIS et al., 1985). Segundo HUDSON et al. (1975a), o ascorbato de cálcio é um dos mais úteis aditivos para melhorar a textura. Para que o cálcio seja um efetivo agente firmador, um baixo grau de metoxilação deve ser utilizado (WESCHE-EBELING \& MONTGOMERY, 1990). Após o processamento térmico, frutos inteiros mantêm uma integridade melhor do que o fruto fatiado (MAIN et al., 1986).

Pela Tabela 7 observa-se que para a variedade Chandler, os tratamentos, quando comparados entre si, não provocaram efeitos significativos na textura; já, para a variedade Reiko, os tratamentos 3 e 6, que utilizaram cloreto de cálcio firmaram mais os frutos do que os tratamentos que utilizaram pectina ( 2 e 5). Em estudos realizados por ESKIN (1991), a firmeza dos morangos fatiados foi também melhorada aplicando-se cálcio, pectina e colóides no preparo dos frutos antes do congelamento.

De maneira geral, a qualidade dos frutos foi influenciada pelo período de estocagem, ou seja, à medida que o armazenamento prolongou-se, houve um decréscimo na textura (Figuras 9 e 10).

Observa-se, pelas Tabelas 1 e 7 que a textura dos frutos "in natura" apresentou maiores valores que a dos frutos termicamente processados para ambas as variedades em estudo, estando de acordo com pesquisas realizadas por BOURNE (1982) e ESKIN (1991), nas quais concluíram que a textura de 


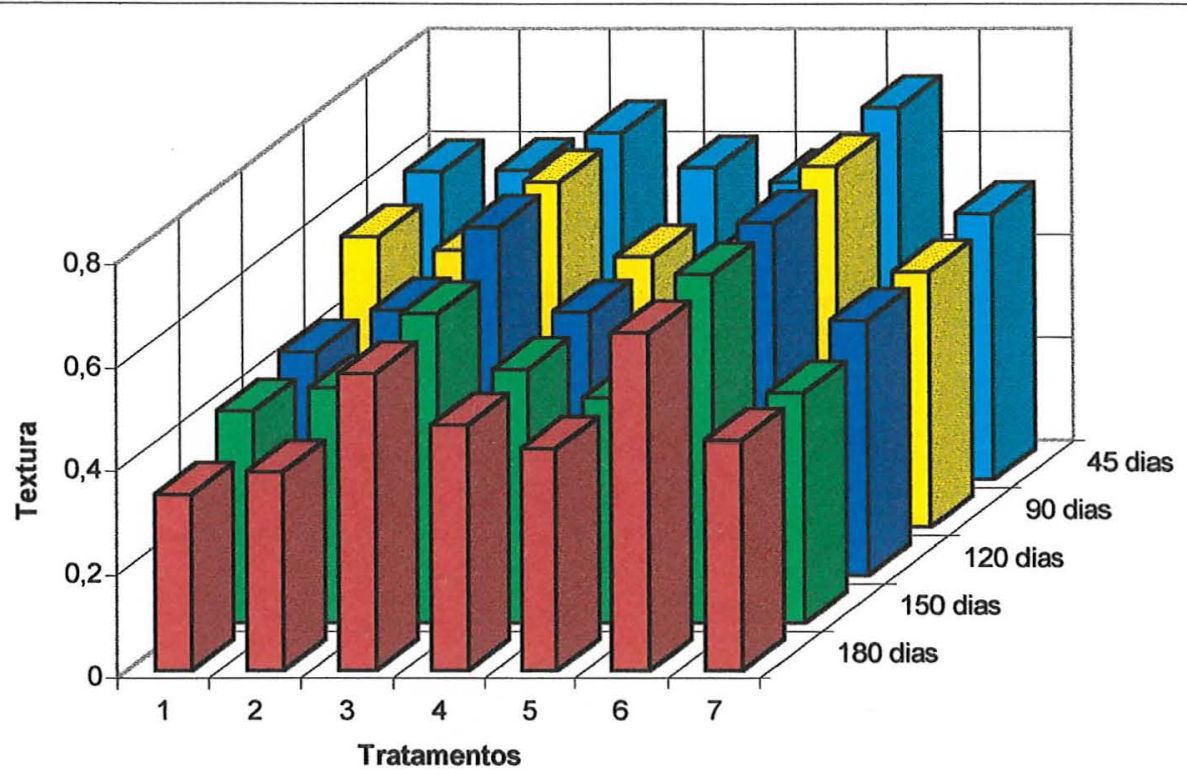

Figura 9. Variação da textura (Ibf/g de fruto) de acordo com os períodos de armazenamento - Variedade Chandler.

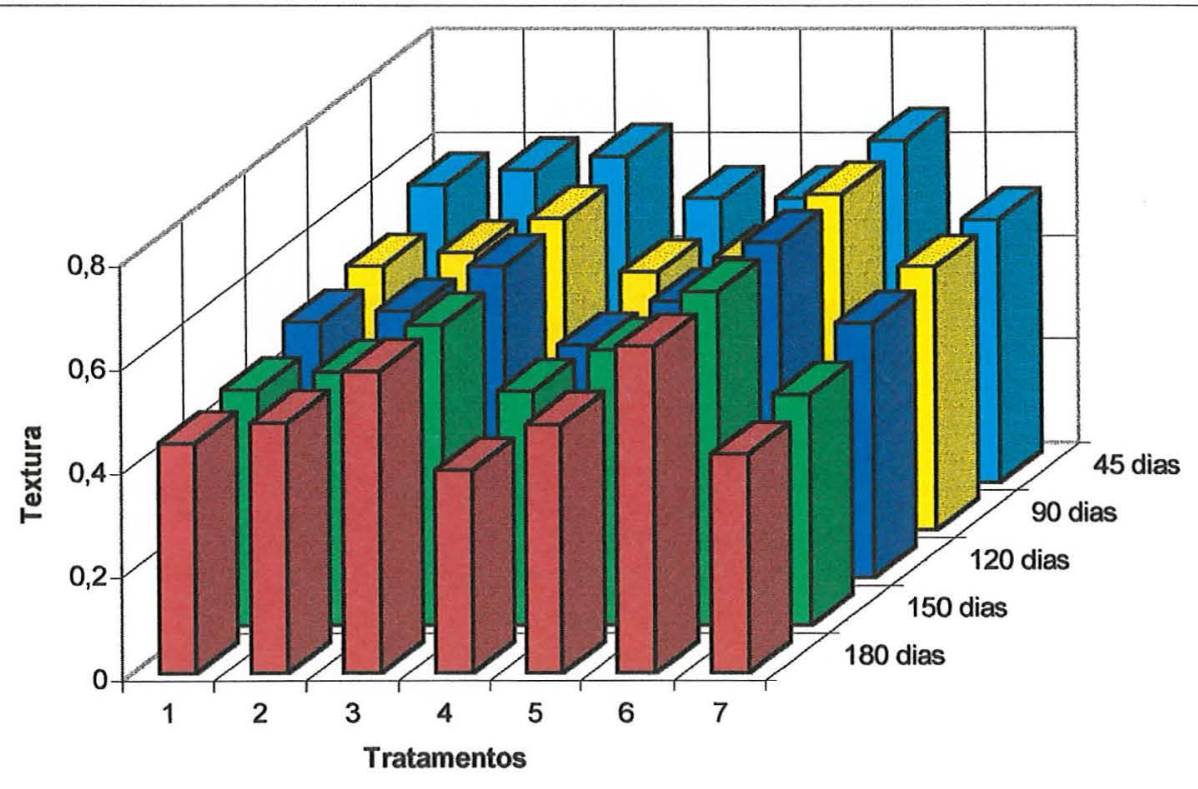

Figura 10. Variação da textura (Ibf/g de fruto) de acordo com os períodos de armazenamento - Variedade Reiko. 
morangos diminui drasticamente com a temperatura de processamento e tempo de estocagem.

Com relação à medida de vácuo (Tabela 8) observa-se que para a variedade Chandler 0 tratamento 6 diferiu dos tratamentos 1,4 e 5 e estes não diferiram dos demais; para a variedade Reiko 0 tratamento 5 diferiu significativamente dos demais tratamentos (Figuras 11 e 12).

Os valores médios de vácuo foram de 11,23 e 12,06 pol. de $\mathrm{Hg}$ para as variedades Chandler e Reiko, respectivamente. Segundo MARTIN (1965) 0 vácuo normal numa lata de fruta em calda deve ser de 8 a 15 polegadas. $O$ vácuo é dependente das operações de exaustão e da temperatura do produto na operação de fechamento das latas. Dentre os fatores intrínsecos que contribuem no processo de vácuo, o oxigênio tem merecido uma grande atenção por parte das indústrias devido ao seu efeito prejudicial, no que diz respeito às reações oxidativas, as quais resultam na deterioração do ácido ascórbico, escurecimento e alterações organolépticas. Vários autores colocam em evidência a ação negativa do oxigênio na vida útil de uma fruta em calda e a necessidade de se adotarem medidas para uma adequada eliminação deste nos processos de enlatamento (CATALÁ, 1980; FERNANDES, 1982).

O oxigênio pode estar na fase gasosa (espaço-livre), dissolvido na fase aquosa ou adsorvido na fase sólida ou semi-sólida (entre as fibras dos tecidos). A temperatura de fechamento do recipiente tem uma importância crucial, contribuindo no processo de vácuo. Os diferentes valores de vácuo obtidos neste trabalho podem ter sido em função da variação de tempo entre a exaustão e a recravação, ou seja, com a variação da temperatura houve um maior acúmulo de oxigênio gasoso, o que ocasionou um menor valor de vácuo, considerando que o limite do espaço-livre nas latas foi, de uma maneira geral, uniforme. Um outro fator causador desta variação de vácuo poderia ter sido em função da variação de temperatura no centro geométrico da lata. A temperatura de exaustão, 


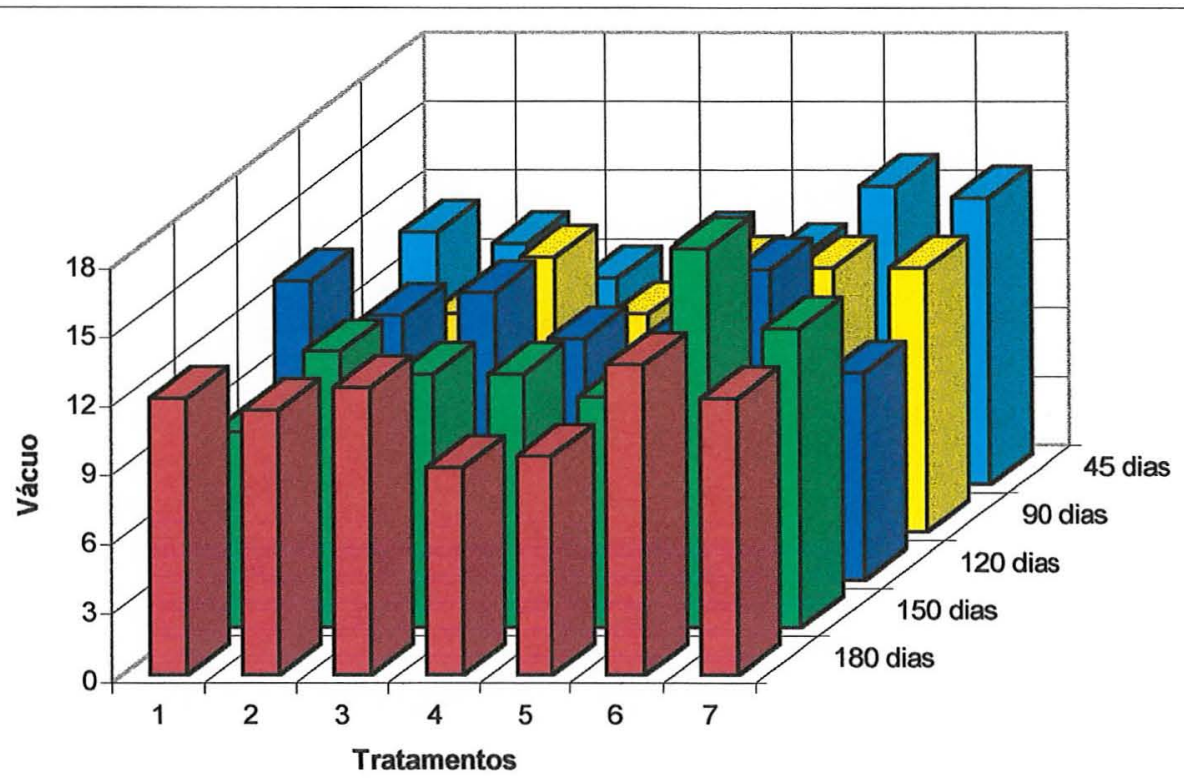

Figura 11. Variação do vácuo (pol. Hg) de acordo com os períodos de armazenamento - Variedade Chandler.

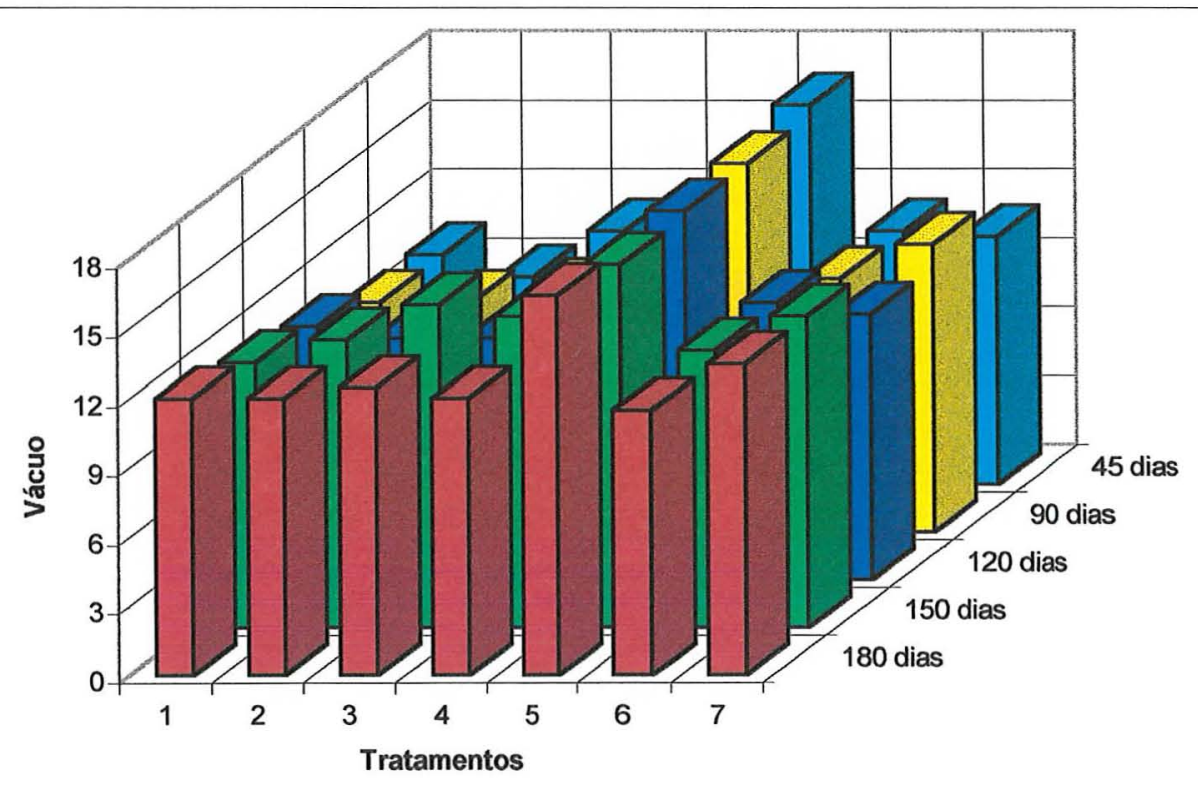

Figura 12. Variação do vácuo (pol. Hg) de acordo com os períodos de armazenamento - Variedade Reiko. 
conforme citada anteriormente $\left(85^{\circ} \mathrm{C}\right)$ está de acordo com recomendações feitas por MARTIN (1965), que indica temperaturas entre 82 e $96^{\circ} \mathrm{C}$.

Pela Tabela 8 e Figuras 11 e 12, observa-se que o tratamento 7, apesar de não diferir significativamente dos demais, foi o que obteve valores de vácuo mais constantes $(11,6$ e 12,3, respectivamente para as variedades Chandler e Reiko). Segundo FERNANDES (1982), a adição de ácido ascórbico pode minimizar o problema, podendo reduzir o oxigênio (gasoso) presente no espaço-livre, melhorando assim o vácuo.

\subsubsection{Análises químicas}

Os resultados das avaliações objetivas de $\mathrm{pH}$, acidez total titulável e sólidos solúveis do produto processado são apresentados nas Tabelas 9 a 13 . As análises foram divididas em duas partes: da parte sólida (fruto) e da parte líquida (calda) do produto processado.

Pela Tabelas 9 e 10, observa-se que, para ambas as variedades em estudo, os resultados das análises químicas indicaram que para o pH não houve diferença significativa entre as amostras dos frutos e da calda, o mesmo ocorrendo entre as diferentes épocas de avaliação durante o período de estocagem.

Comparando-se os resultados obtidos para os valores de $\mathrm{pH}$ da matéria-prima (Tabela 2) com os resultados do produto final (Tabela 9), observase que os valores mantiveram-se praticamente estáveis durante todo o período de armazenamento, estando de acordo com GARROTE \& BERTONE (1975), PASCHOALINO (1977), GHERARDI et al. (1983), MAIN et al. (1986), e BERBARI (1992).

No produto final, os valores de $\mathrm{pH}$ dos frutos bem como os da calda apresentaram-se bem semelhantes e não se notou diferença significativa entre os 
Tabela 9. pH dos morangos termicamente processados - parte sólida (frutos).

\begin{tabular}{|c|c|c|c|c|c|c|c|c|c|c|c|c|}
\hline & & & & pH DOS F & RUTOS ( 1 & DIA DAS & NÁLISES & & & & & \\
\hline & & & Chandler & & & & & & Reiko & & & \\
\hline TRATAMENTOS & $45^{\circ} \mathrm{DIA}$ & $90^{\circ} \mathrm{DIA}$ & $120^{\circ} \mathrm{DIA}$ & $150^{\circ} \mathrm{DIA}$ & $180^{\circ} \mathrm{DIA}$ & MEDIA & $45^{\circ} \mathrm{DIA}$ & $90^{\circ} \mathrm{DIA}$ & $120^{\circ} \mathrm{DIA}$ & $150^{\circ} \mathrm{DIA}$ & $180^{\circ} \mathrm{DIA}$ & MEDIA \\
\hline 1 & 3,21 & 3,66 & 3,27 & 3,33 & 3,37 & $3,37^{\mathrm{A}}$ & 3,47 & 3,38 & 3,41 & 3,44 & 3,61 & $3,46^{A}$ \\
\hline 2 & 3,61 & 3,17 & 3,25 & 3,39 & 3,35 & $3,35 \mathrm{~A}$ & 3,48 & 3,30 & 3,34 & 3,57 & 3,42 & 3,42 \\
\hline 3 & 3,12 & 3,18 & 3,41 & 3,22 & 3,33 & $3,25 \mathrm{~A}$ & 3,23 & 3,53 & 3,14 & 3,22 & 3,23 & $3,27 \quad \mathrm{~A}$ \\
\hline 4 & 3,68 & 3,37 & 3,63 & 3,39 & 3,43 & $3,50 \mathrm{~A}$ & 3,37 & 3,57 & 3,35 & 3,44 & 3,38 & 3,42 \\
\hline 5 & 3,31 & 3,69 & 3,39 & 3,36 & 3,36 & $3,42 \mathrm{~A}$ & 3,36 & 3,43 & 3,77 & 3,53 & 3,34 & 3,49 \\
\hline 6 & 3,37 & 3,20 & 3,54 & 3,17 & 3,37 & $3,33 \mathrm{~A}$ & 3,04 & 3,49 & 3,11 & 3,17 & 3,36 & 3,23 \\
\hline 7 & 3,35 & 3,31 & 3,39 & 3,65 & 3,38 & $3,42^{\mathrm{A}}$ & 3,18 & 3,28 & 3,67 & 3,54 & 3,52 & 3,44 \\
\hline EPOCAS DE AVAL. & $3,38^{\mathrm{a}}$ & $3,37^{a}$ & $3,41^{\mathrm{a}}$ & $3,36^{a}$ & $3,37^{\mathrm{a}}$ & & $3,30^{\mathrm{a}}$ & $3,43^{\mathrm{a}}$ & $3,40^{\mathrm{a}}$ & $3,42^{a}$ & $3,41^{a}$ & \\
\hline $\begin{array}{l}\text { F (Tratamentos) } \\
\text { F (Épocas de aval.) }\end{array}$ & & & $\begin{array}{l}1,21 \text { n.s. } \\
0,11 \text { n.s. }\end{array}$ & & & & & & $\begin{array}{l}2,06 \\
0,73\end{array}$ & $\begin{array}{l}\text { n.s. } \\
\text { n.s. }\end{array}$ & & \\
\hline
\end{tabular}

n.s. - não significativo a nível de $5 \%$

* - significativo a nível de $5 \%$

** - significativo a nível de $1 \%$.

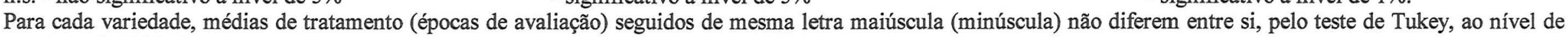
$5 \%$ de probabilidade.

Tabela 10. pH dos morangos termicamente processados - parte líquida (calda).

\begin{tabular}{|c|c|c|c|c|c|c|c|c|c|c|c|c|}
\hline \multicolumn{13}{|c|}{ pH DA CALDA (MÉDIA DAS ANÁLISES) } \\
\hline \multicolumn{9}{|c|}{ Chandler } & \multicolumn{4}{|l|}{ Reiko } \\
\hline TRATAMENTOS & $45^{\circ} \mathrm{DIA}$ & $90^{\circ} \mathrm{DIA}$ & $120^{\circ} \mathrm{DIA}$ & $150^{\circ} \mathrm{DIA}$ & $180^{\circ} \mathrm{DIA}$ & MÉDIA & $45^{\circ} \mathrm{DIA}$ & $90^{\circ} \mathrm{DIA}$ & $120^{\circ} \mathrm{DIA}$ & $150^{\circ} \mathrm{DIA}$ & $180^{\circ} \mathrm{DIA}$ & MÉDIA \\
\hline 1 & 3,21 & 3,66 & 3,29 & 3,31 & 3,36 & $3,37^{\mathrm{A}}$ & 3,42 & 3,37 & 3,39 & 3,44 & 3,61 & $3,42^{\mathrm{A}}$ \\
\hline 2 & 3,60 & 3,15 & 3,26 & 3,30 & 3,35 & $3,33 \mathrm{~A}$ & 3,37 & 3,40 & 3,33 & 3,57 & 3,43 & 3,42 \\
\hline 3 & 3,10 & 3,11 & 3,41 & 3,21 & 3,36 & $3,24 \mathrm{~A}$ & 3,23 & 3,50 & 3,14 & 3,13 & 3,23 & 3,25 \\
\hline 4 & 3,69 & 3,40 & 3,63 & 3,37 & 3,43 & $3,50 \mathrm{~A}$ & 3,35 & 3,57 & 3,34 & 3,42 & 3,38 & 3,41 \\
\hline 5 & 3,26 & 3,66 & 3,40 & 3,35 & 3,37 & 3,41 A & 3,37 & 3,46 & 3,76 & 3,55 & 3,33 & 3,49 \\
\hline 6 & 3,38 & 3,20 & 3,51 & 3,20 & 3,35 & $3,33 \mathrm{~A}$ & 3,19 & 3,51 & 3,14 & 3,17 & 3,34 & 3,27 \\
\hline 7 & 3,32 & 3,31 & 3,40 & 3,62 & 3,38 & 3,41 A & 3,37 & 3,26 & 3,60 & 3,53 & 3,50 & 3,45 \\
\hline ËPCAS DE AVAL. & $3,37^{\mathrm{a}}$ & $3,36^{a}$ & $3,41^{\mathrm{a}}$ & $3,34^{\mathrm{a}}$ & $3,37^{\mathrm{a}}$ & & $3,33^{a}$ & $3,44^{a}$ & $3,39^{a}$ & $3,40^{a}$ & $3,40^{\mathrm{a}}$ & \\
\hline $\mathrm{F}$ (Tratamentos) & & & 1,39 n.s. & & & & & & 2,49 & n.s. & & \\
\hline F (Épocas de aval.) & & & 0,23 n.s. & & & & & & 0,62 & n.s. & & \\
\hline
\end{tabular}

n.s. - não significativo a nível de $5 \%$

* - significativo a nível de $5 \%$

** - significativo a nível de $1 \%$.

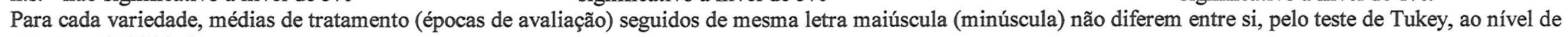
$5 \%$ de probabilidade. 


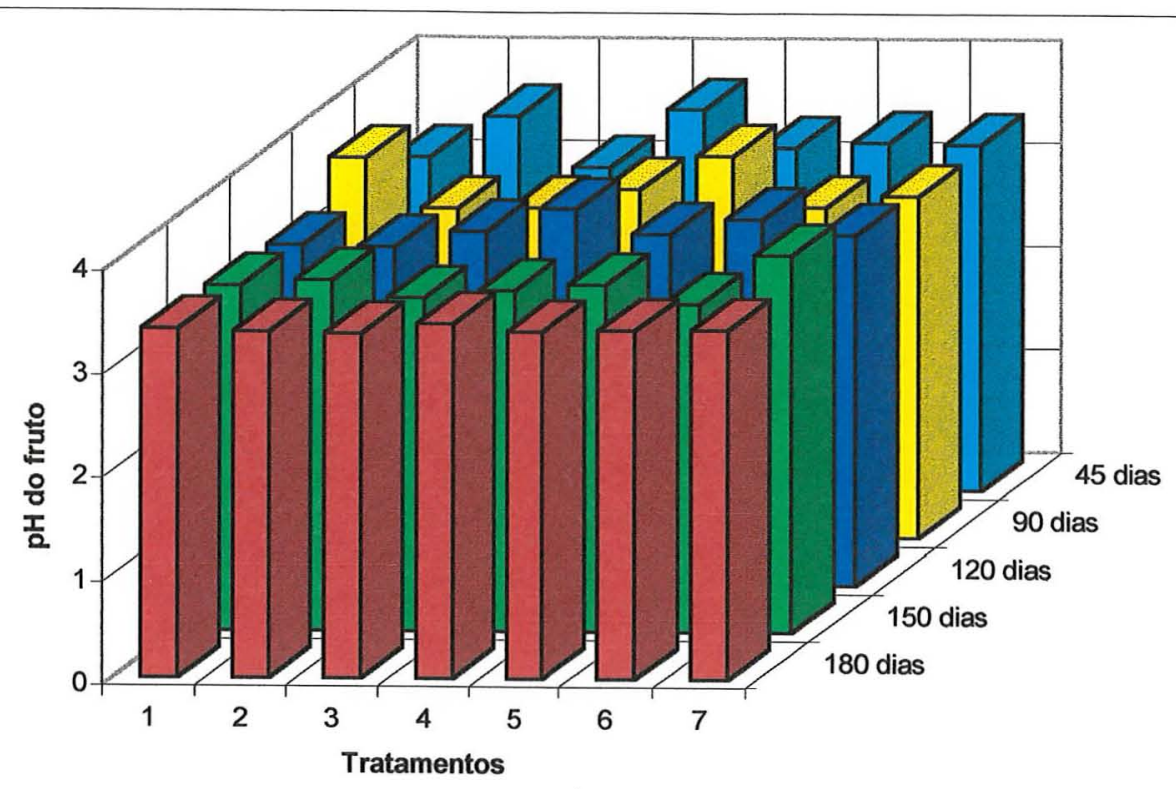

Figura 13. Variação do pH (parte sólida: frutos) de acordo com os períodos de armazenamento - Variedade Chandler.

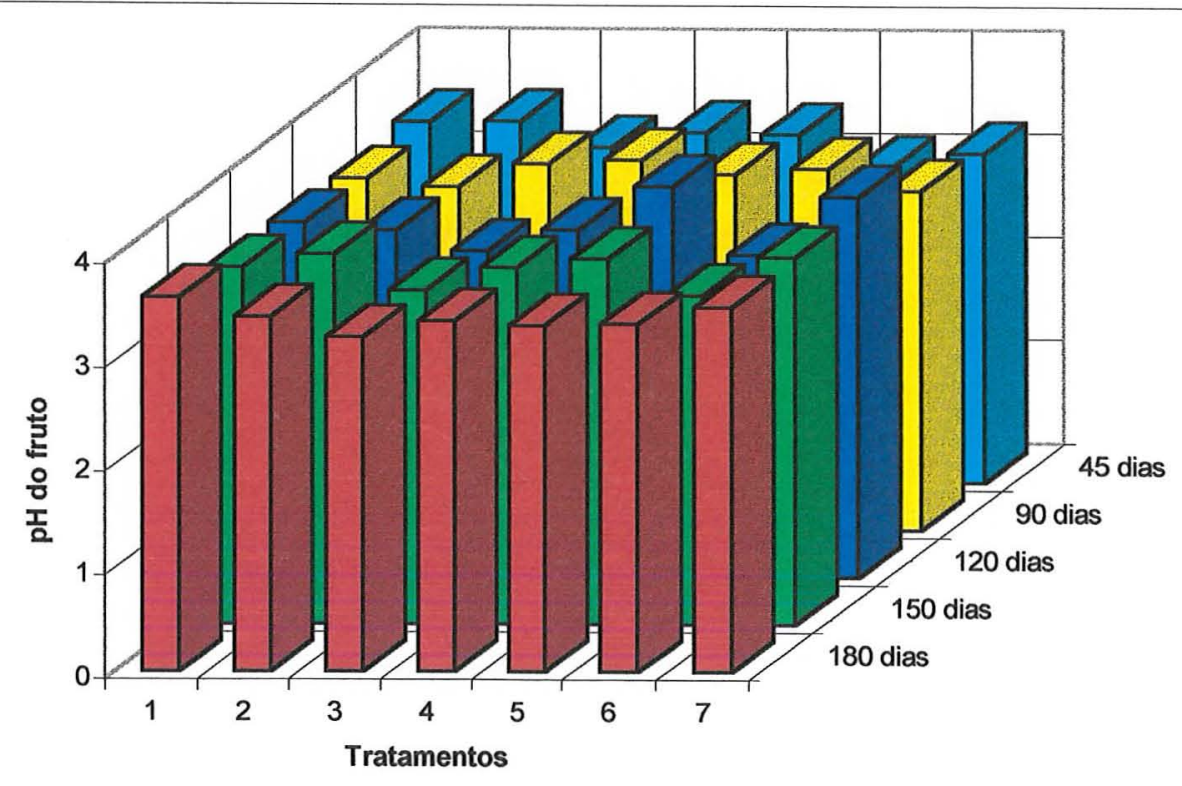

Figura 14. Variação do pH (parte sólida: frutos) de acordo com os períodos de armazenamento - Variedade Reiko. 


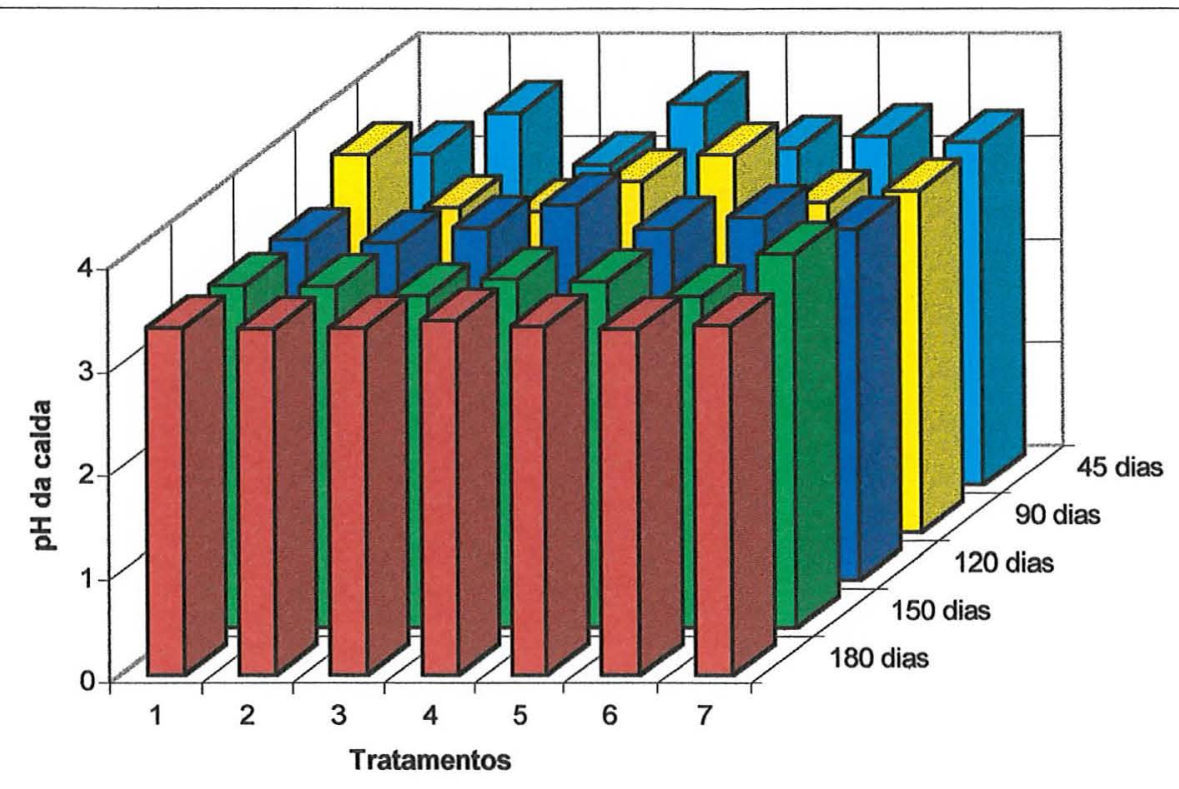

Figura 15. Variação do pH (parte líquida: calda) de acordo com os períodos de armazenamento - Variedade Chandler.

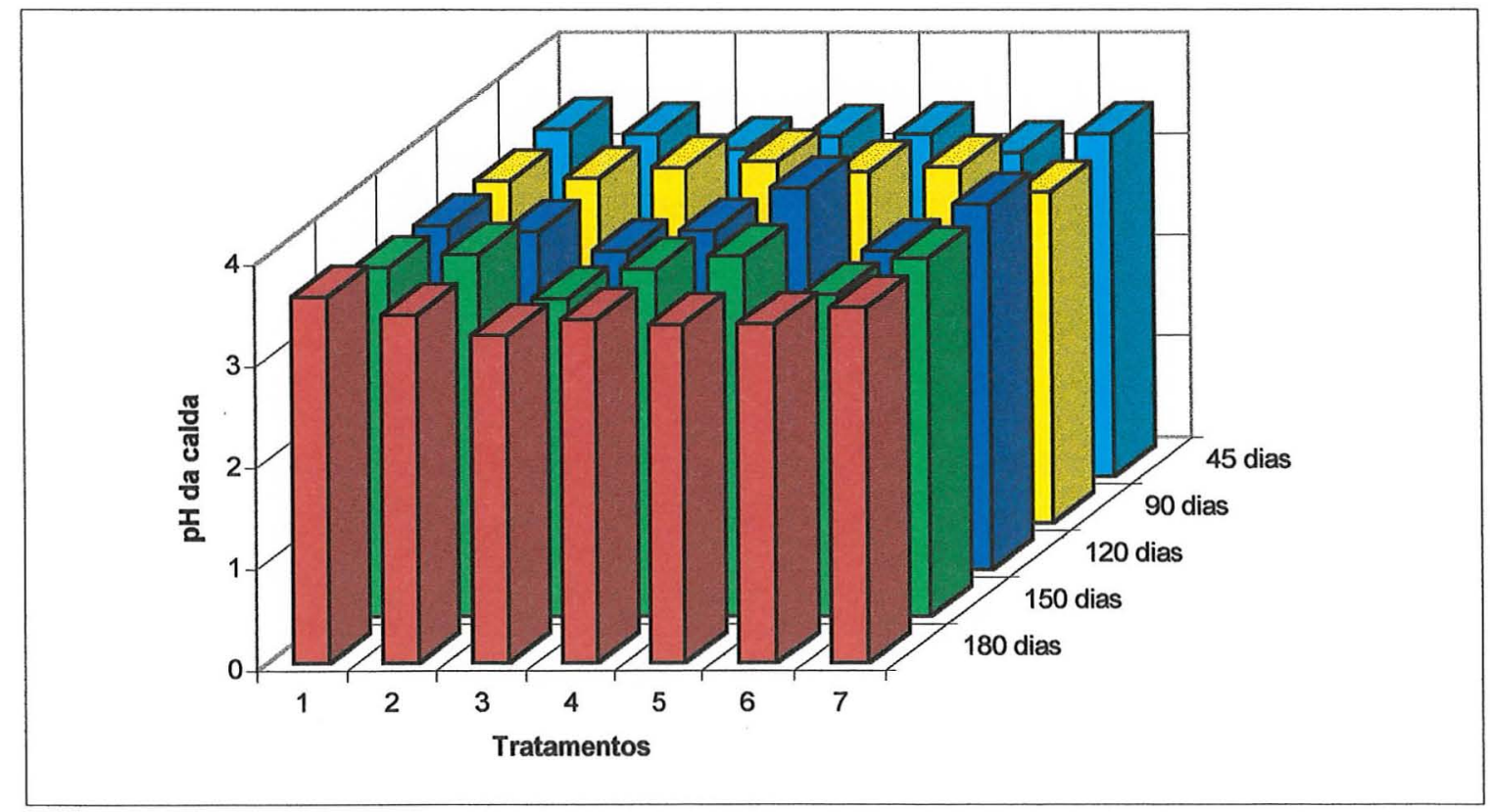

Figura 16. Variação do $\mathrm{pH}$ (parte líquida: calda) de acordo com os períodos de armazenamento - Variedade Reiko. 
tratamentos (Figuras 13, 14, 15 e 16). Os valores de $\mathrm{pH}$ apresentados pelas variedades em estudo estão de acordo com ESKIN (1991), que observou ser 0 $\mathrm{pH}$ o componente que mais contribui para a estabilidade da cor dos morangos. Morangos devem possuir um $\mathrm{pH}$ abaixo de 3,51 , sendo que em valor superior a este promove a degradação das antocianinas. Segundo HUDSON et al. (1975a), o pH é a única medida objetiva correlacionada com a qualidade da cor.

Com relação à acidez total titulável, conforme pode ser verificado pela Tabela 11, para a variedade Chandler o tratamento 2 diferiu dos tratamentos 6 e 7 e os demais tratamentos não diferiram entre si; para a variedade Reiko, o tratamento 1 diferiu dos tratamentos 4, 5,6 e 7, porém não diferiu dos tratamentos 2 e 3. Estes dois últimos não diferiram dos demais tratamentos. Não houve diferença significativa em relação às diferentes épocas de avaliação durante o período de armazenamento (Figuras 17 e 18).

Estes resultados mostraram-se semelhantes aos obtidos por PASCHOALINO (1977) encontrou 0,74\%; GHERARDI et al. (1983) encontraram valores entre 0,61 a 1,22\% e MAIN et al. (1986), que encontraram valores entre 0,60 a $0,70 \%$ de ácido cítrico. Valores maiores de acidez foram encontrados por GARROTE \& BERTONE (1976) encontraram valores entre 0,99 e 1,74\%; SELVARAJ et al. (1976) valores entre 0,72 e 1,76\% e BERBARI (1992), que variaram de 0,73 a $1,88 \%$ para a variedade Reiko e de 0,71 a $1,06 \%$ para a variedade Chandler.

Com relação ao teor de sólidos solúveis (Tabelas 12 e 13), os resultados para a variedade Chandler mostraram que o tratamento 1 diferiu dos tratamentos 3 e 7 e estes últimos não diferiram dos demais tratamentos; para a variedade Reiko, o tratamento 1 diferiu dos tratamentos 2,4 e 5 e, estes não diferiram dos demais tratamentos. $O$ tratamento 1 não diferiu dos tratamentos 3,6 e 7. Para a variedade Chandler, o tratamento 1 foi o que apresentou maior média e o tratamento 3 a menor; já, para a variedade Reiko, o tratamento 1 foi 0 de menor média, tanto para o fruto como para a calda (Figuras 19 e 20). Os valores 
Tabela 11. Acidez total titulável ( $\mathrm{g}$ ácido cítrico/100 $\mathrm{g}$ amostra) dos morangos termicamente processados.

\begin{tabular}{|c|c|c|c|c|c|c|c|c|c|c|c|c|}
\hline \multicolumn{13}{|c|}{ ACIDEZ ( MEDIA DAS ANÁLISES) } \\
\hline \multicolumn{9}{|c|}{ ) } & \multicolumn{4}{|l|}{ Reiko } \\
\hline TRATAMENTOS & $45^{\circ} \mathrm{DIA}$ & $90^{\circ} \mathrm{DIA}$ & $120^{\circ} \mathrm{DIA}$ & $150^{\circ} \mathrm{DIA}$ & $180^{\circ} \mathrm{DIA}$ & MÉDIA & $45^{\circ} \mathrm{DIA}$ & $90^{\circ} \mathrm{DIA}$ & $120^{\circ} \mathrm{DIA}$ & $150^{\circ} \mathrm{DIA}$ & $180^{\circ} \mathrm{DIA}$ & MÉDIA \\
\hline 1 & 0,7618 & 0,6210 & 0,6658 & 0,6178 & 0,7939 & $0,6921^{\mathrm{ABC}}$ & 0,6338 & 0,6850 & 0,6562 & 0,6882 & 0,6242 & $0,6575^{B}$ \\
\hline 2 & 0,7490 & 0,7492 & 0,7490 & 0,7745 & 0,7714 & 0,7586 A & 0,6242 & 0,7714 & 0,7426 & 0,7650 & 0,7330 & $0,7272^{\mathrm{AB}}$ \\
\hline 3 & 0,6626 & 0,6498 & 0,7042 & 0,6290 & 0,6658 & $0,6623^{\mathrm{ABC}}$ & 0,7506 & 0,7554 & 0,7426 & 0,7811 & 0,7202 & $0,7500^{\mathrm{AB}}$ \\
\hline 4 & 0,7682 & 0,6850 & 0,6242 & 0,6754 & 0,5570 & $0,6620^{\mathrm{ABC}}$ & 0,7554 & 0,8019 & 0,8035 & 0,7362 & 0,7522 & $0,7698^{A}$ \\
\hline 5 & 0,7458 & 0,6850 & 0,7875 & 0,6914 & 0,7490 & $0,7317^{\mathrm{AB}}$ & 0,7634 & 0,8067 & 0,7666 & 0,9091 & 0,8195 & $0,8131^{\mathrm{A}}$ \\
\hline 6 & 0,6498 & 0,5794 & 0,6130 & 0,6434 & 0,6370 & $0,6245^{C}$ & 0,8195 & 0,6306 & 0,8355 & 0,8419 & 0,6978 & $0,7651^{\mathrm{A}}$ \\
\hline 7 & 0,6050 & 0,6978 & 0,6754 & 0,6050 & 0,6498 & $0,6466^{\mathrm{BC}}$ & 0,8291 & 0,8355 & 0,7779 & 0,8931 & 0,7490 & $0,8169^{\mathrm{A}}$ \\
\hline ÉPOCAS DE AVAL. & $0,7060^{\mathrm{a}}$ & $0,667^{\mathrm{a}}$ & $0,6884^{\mathrm{a}}$ & $0,6624^{\mathrm{a}}$ & $0,6891^{\mathrm{a}}$ & & $0,7394^{\mathrm{a}}$ & $0,7552^{a}$ & $0,7607^{\mathrm{a}}$ & $0,8021^{\mathrm{a}}$ & $0,7280^{\mathrm{a}}$ & \\
\hline F (Tratamentos) & & & $4,36 * *$ & & & & & & 5,58 & ** & & \\
\hline F (Épocas de aval.) & & & 0,85 n.s. & & & & & & 2,11 & n.s. & & \\
\hline
\end{tabular}

n.s. - não significativo a nível de $5 \% \quad * \quad$ - significativo a nível de $5 \% \quad * * \quad$ - significativo a nível de $1 \%$.

Para cada variedade, médias de tratamento (épocas de avaliação) seguidos de mesma letra maiúscula (minúscula) não diferem entre si, pelo teste de Tukey, ao nível de $5 \%$ de probabilidade.

Tabela 12. Sólido solúveis (Brix) dos morangos termicamente processados - parte sólida (frutos).

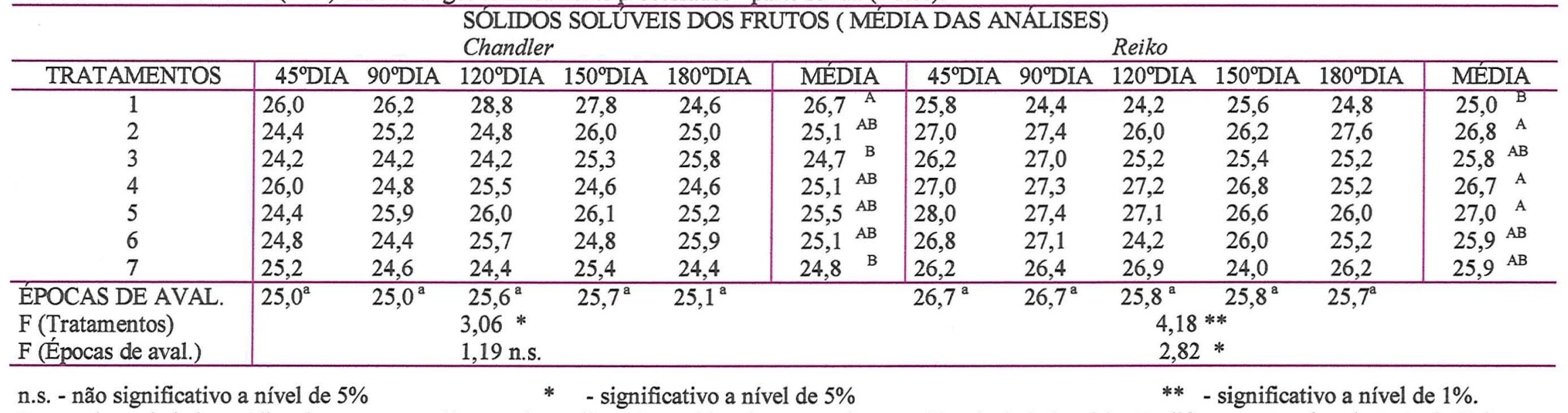

n.s. - não significativo a nível de $5 \%$

* - significativo a nível de $5 \%$

** - significativo a nível de $1 \%$.

Para cada variedade, médias de tratamento (épocas de avaliação) seguidos de mesma letra maiúscula (minúscula) não diferem entre si, pelo teste de Tukey, ao nível de $5 \%$ de probabilidade. 
Tabela 13. Sólido solúveis (Brix) dos morangos termicamente processados - parte líquida (calda).

\begin{tabular}{|c|c|c|c|c|c|c|c|c|c|c|c|c|}
\hline \multicolumn{13}{|c|}{ SÓLIDOS SOLÚVEIS DA CALDA ( MÉDIA DAS ANÁLISES) } \\
\hline \multicolumn{9}{|c|}{ Chandler } & \multicolumn{4}{|l|}{ Reiko } \\
\hline TRATAMENTOS & $45^{\circ} \mathrm{DIA}$ & $90^{\circ} \mathrm{DIA}$ & $120^{\circ} \mathrm{DIA}$ & $150^{\circ} \mathrm{DIA}$ & $180^{\circ} \mathrm{DIA}$ & MÉDIA & $45^{\circ} \mathrm{DIA}$ & 90'DIA & $120^{\circ} \mathrm{DIA}$ & $150^{\circ} \mathrm{DIA}$ & $180^{\circ} \mathrm{DIA}$ & MÉDIA \\
\hline 1 & 27,2 & 26,6 & 30,0 & 28,6 & 24,6 & $27,4^{\mathrm{A}}$ & 25,4 & 24,6 & 24,4 & 25,8 & 25,8 & $25,2^{\mathrm{A}}$ \\
\hline 2 & 24,7 & 26,0 & 25,0 & 26,0 & 25,1 & 25,4 B & 26,9 & 27,0 & 26,2 & 26,4 & 28,2 & 26,9 A \\
\hline 3 & 24,4 & 23,8 & 24,6 & 25,2 & 26,0 & $24,8 \quad$ B & 26,4 & 27,6 & 25,4 & 25,6 & 25,4 & $26,1^{A}$ \\
\hline 4 & 26,0 & 25,8 & 25,6 & 24,8 & 25,0 & 25,4 AB & 27,2 & 26,6 & 27,4 & 26,6 & 25,2 & $26,6^{A}$ \\
\hline 5 & 24,2 & 26,3 & 25,8 & 26,2 & 25,0 & $25,5 \mathrm{AB}$ & 28,0 & 27,2 & 27,2 & 24,8 & 26,6 & $26,8^{A}$ \\
\hline 6 & 25,0 & 23,8 & 25,7 & 25,2 & 24,6 & 24,9 B & 26,8 & 26,8 & 24,4 & 26,2 & 26,2 & 26,1 A \\
\hline 7 & 25,2 & 25,0 & 24,2 & 25,5 & 24,8 & 24,9 B & 26,2 & 25,2 & 26,9 & 26,8 & 27,0 & $26,4^{A}$ \\
\hline ÉPOCAS DE AVAL. & $25,2^{a}$ & $25,3^{a}$ & $25,8^{a}$ & $25,9^{a}$ & $25,0^{a}$ & & $26,7^{a}$ & $26,4^{a}$ & $26,0^{a}$ & $26,0^{a}$ & $26,3^{a}$ & \\
\hline F (Tratamentos) & & & $4,07 * *$ & & & & & & 2,01 & n.s. & & \\
\hline F (Épocas de aval.) & & & 1,11 n.s. & & & & & & 0,73 & n.s. & & \\
\hline
\end{tabular}

$\begin{array}{lccc}\text { n.s. - não significativo a nível de } 5 \% & * & \text { - significativo a nível de } 5 \% & * * \\ \text { Para cada variedade, médias de tratamento (épocas de avaliação) seguidos de mesma letra maiúscula (minúscula) não diferem entre si, pelo teste de Tukey, ao nível de }\end{array}$ $5 \%$ de probabilidade.

Tabela 14. Vitamina C (mg / $100 \mathrm{~g}$ amostra) dos morangos termicamente processados.

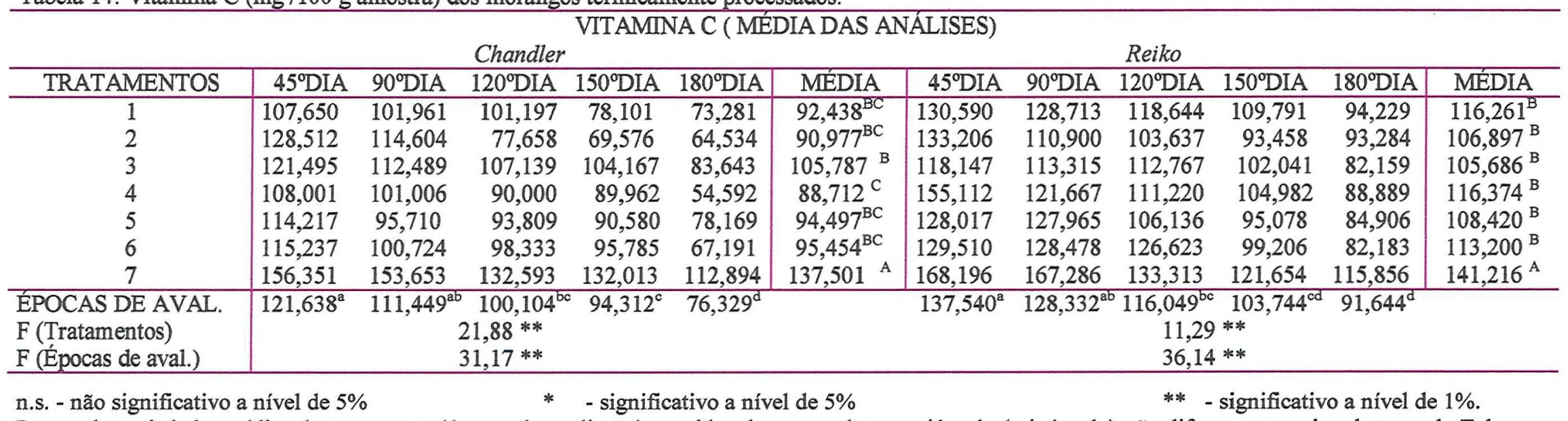

Para cada variedade, médias de tratamento (épocas de avaliação) seguidos de mesma letra maiúscula (minúscula) não diferem entre si, pelo teste de Tukey, ao nível de $5 \%$ de probabilidade. 


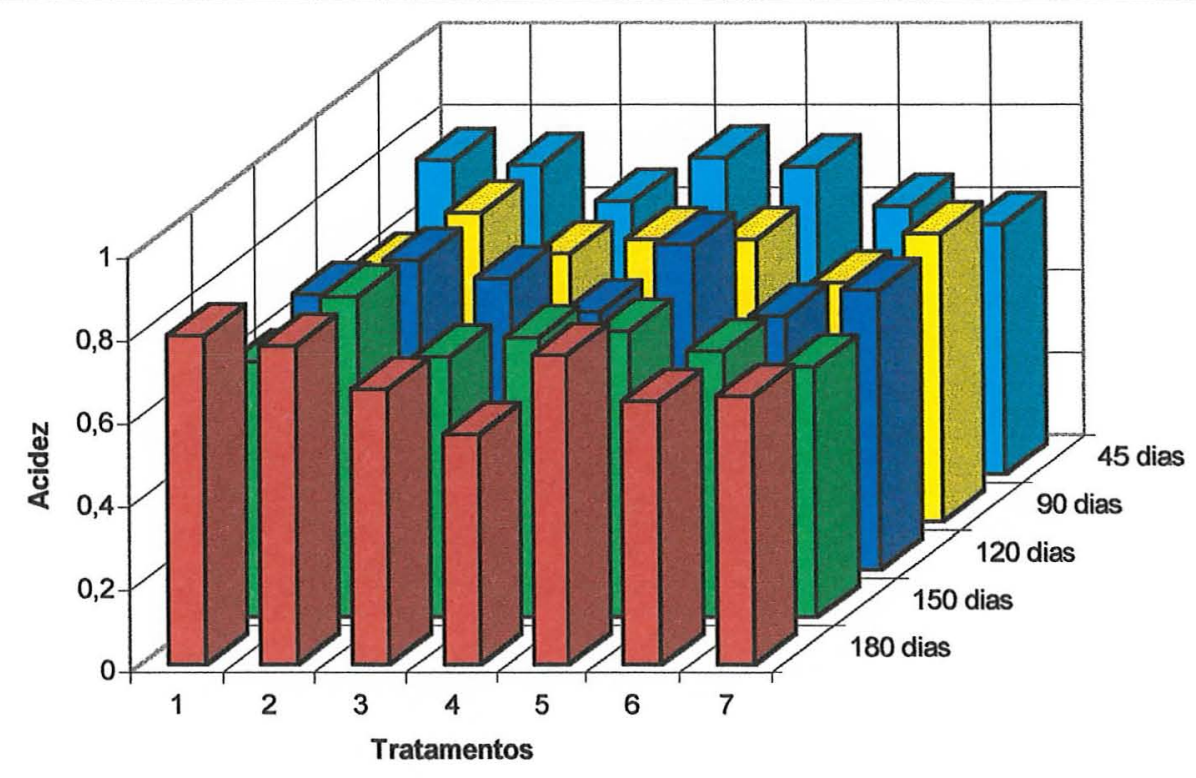

Figura 17. Variação da acidez total titulável (g de ácido cítrico/100 g de amostra) de acordo com os períodos de armazenamento - Variedade Chandler.

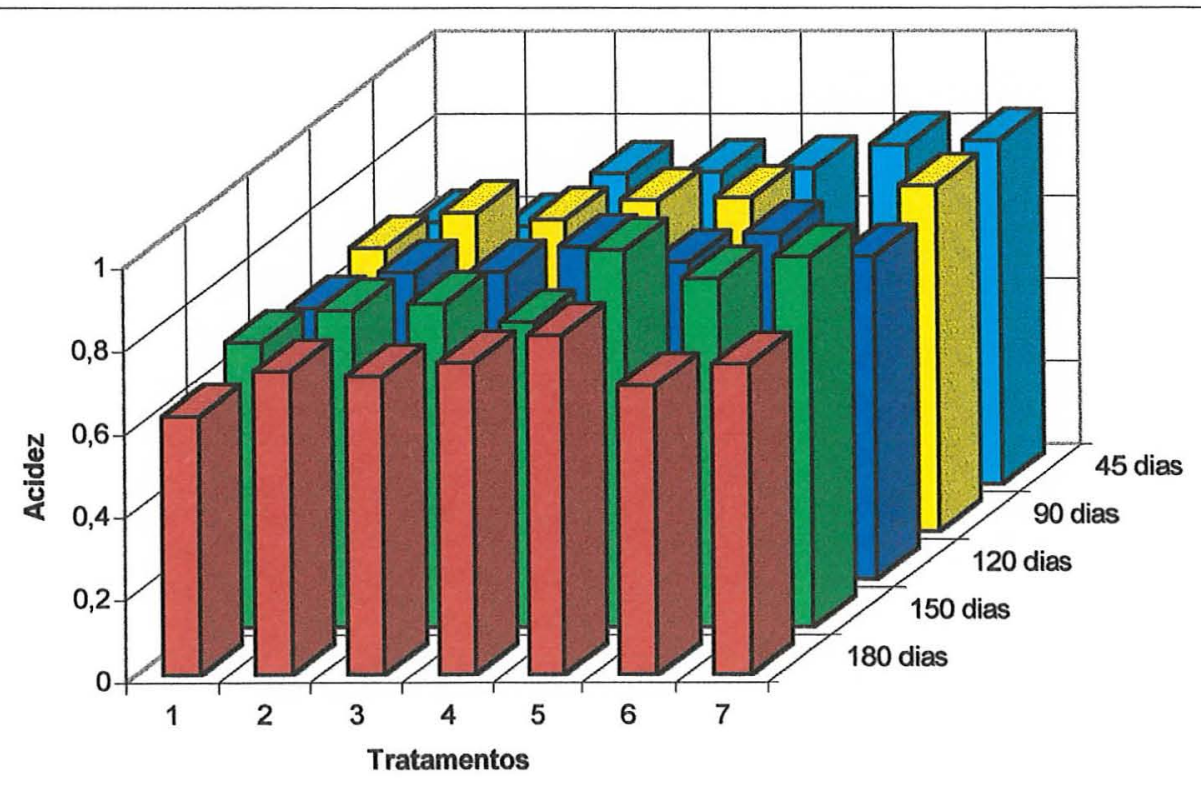

Figura 18. Variação da acidez total titulável ( $\mathrm{g}$ de ácido cítrico/100 g de amostra) de acordo com os períodos de armazenamento - Variedade Reiko. 


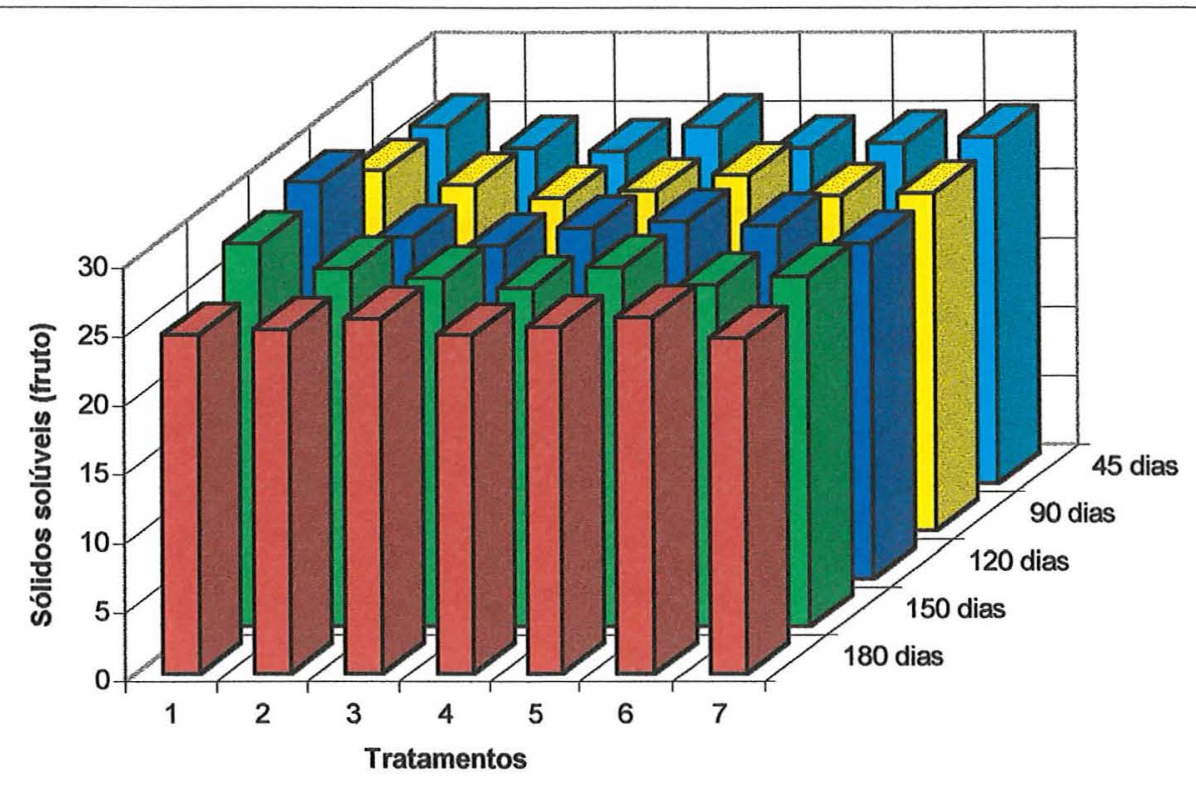

Figura 19. Variação dos sólidos solúveis (parte sólida: frutos) de acordo com os períodos de armazenamento - Variedade Chandler.

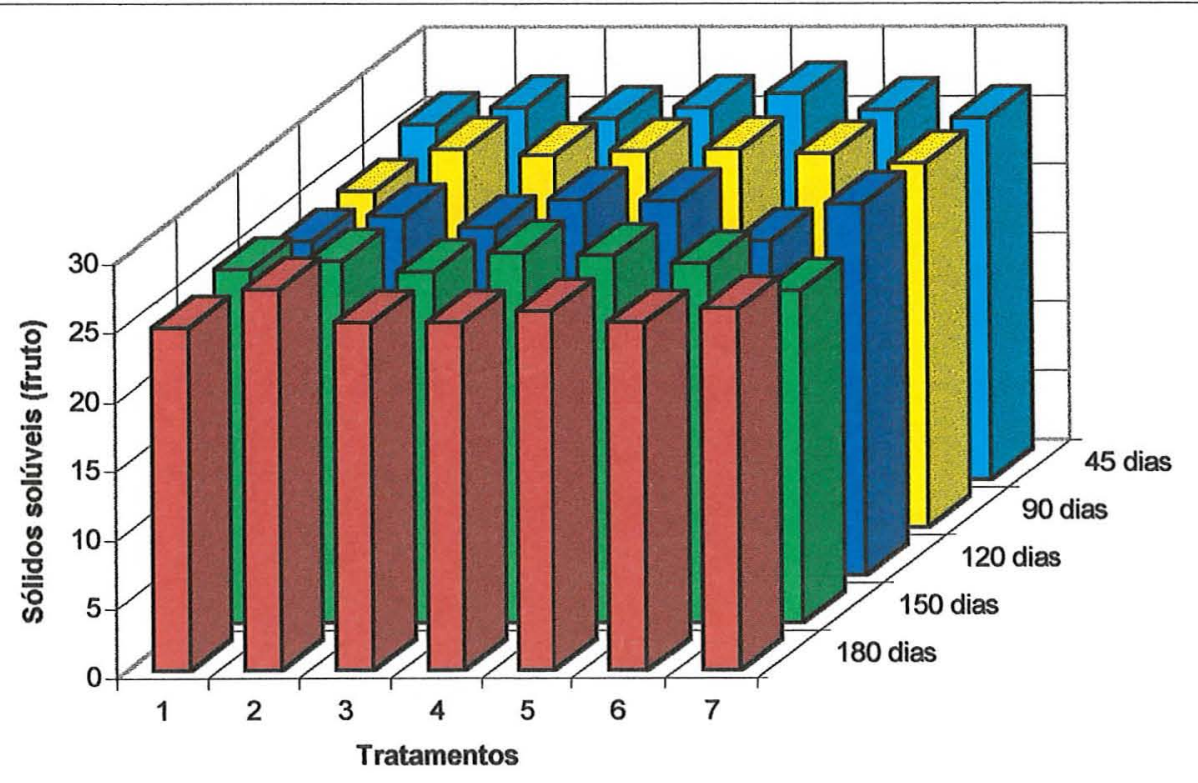

Figura 20. Variação dos sólidos solúveis (parte sólida: frutos) de acordo com os períodos de armazenamento - Variedade Reiko. 
de sólidos solúveis na matéria-prima (Tabela 2) variaram de 8,21 a 9,94\%, enquanto que no produto final se situaram entre 24,7 a $27,0 \%$, o que mostra uma elevação do teor de sólidos solúveis em conseqüência da aplicação do calor, que propiciou uma maior troca osmótica entre o açúcar adicionado e os frutos.

Não houve para ambas variedades diferenças significativas entre as diferentes épocas de avaliação durante o período de armazenamento.

Quanto ao teor de sólidos solúveis da calda, Tabela 13, observa-se que, para a variedade Chandler, o tratamento 1 não diferiu dos tratamentos 4 e 5 e estes não diferiram dos tratamentos 2, 3, 6 e 7; já, para a variedade Reiko, não se observou diferença significativa entre os tratamentos (Figuras 21 e 22).

Os teores de vitamina $\mathrm{C}$ no produto final para as duas variedades foram menores que os encontrados nos frutos "in natura" (Tabela 14 e 2, respectivamente). De acordo com BERBARI (1992), o tratamento térmico pode acelerar a oxidação da vitamina $\mathrm{C}$.

Para ambas as variedades, o tratamento 7 diferiu dos demais tratamentos, como era esperado, uma vez que este foi enriquecido com vitamina C na proporção de $300 \mathrm{mg} / \mathrm{kg}$ de fruto.

Pela Tabela 14, observa-se que para a variedade Chandler, o tratamento 3 diferiu significativamente do tratamento 4 , porém, estes dois tratamentos não diferiram dos demais tratamentos (1, 2, 5 e 6); para a variedade Reiko, não houve diferença significativa entre os tratamentos. Observa-se que houve diferença significativa entre as épocas de avaliação, o que mostra que durante o armazenamento ocorreram perdas de vitamina $C$ para ambas as variedades.

Embora tenham ocorrido perdas, as variedades apresentaram, ao final de 180 dias de armazenamento, consideráveis teores de vitamina C. Para a 


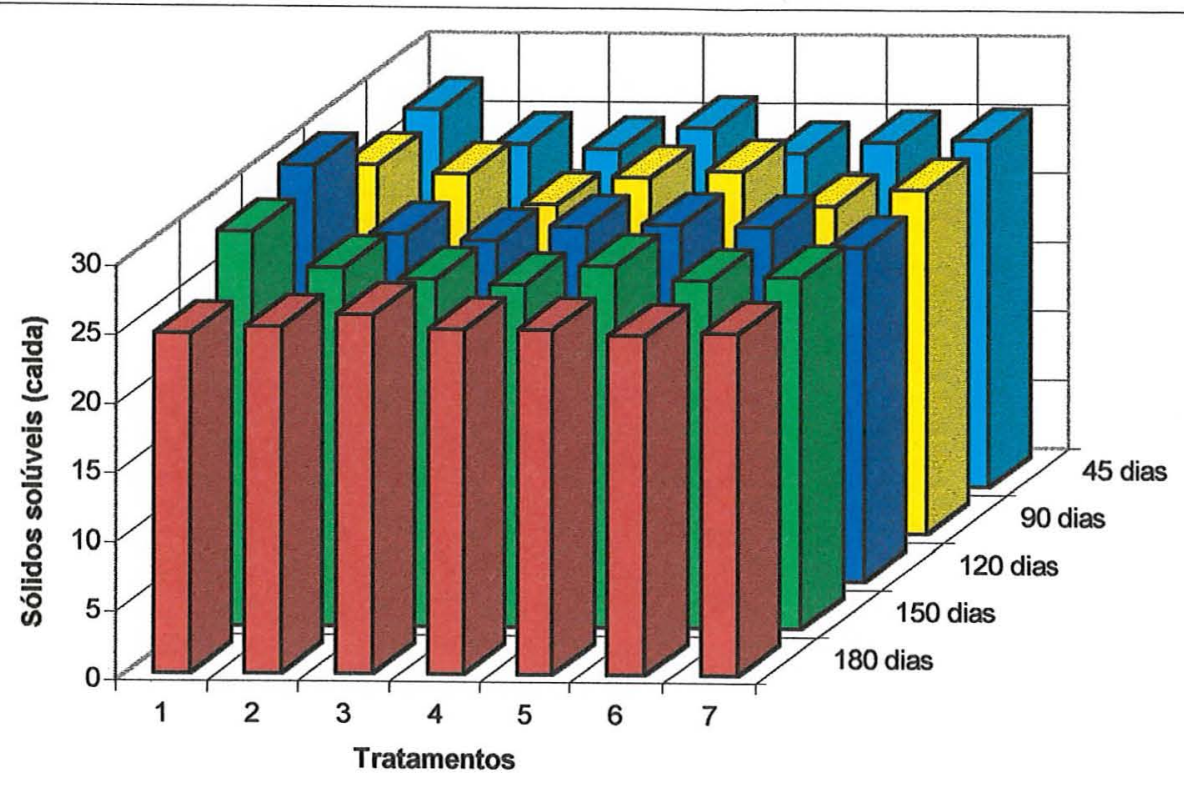

Figura 21. Variação dos sólidos solúveis (parte líquida: calda) de acordo com os períodos de armazenamento - Variedade Chandler.

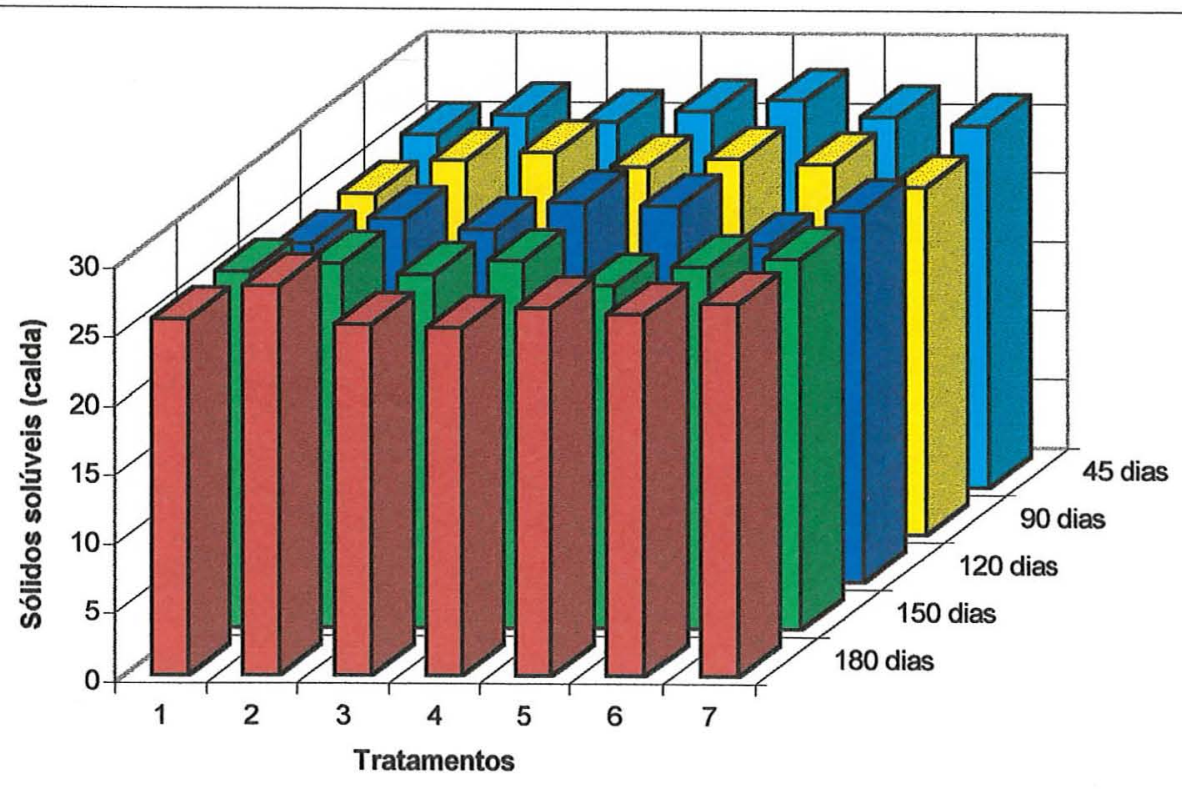

Figura 22. Variação dos sólidos solúveis (parte líquida: calda) de acordo com os períodos de armazenamento - Variedade Reiko. 
variedade Chandler o decréscimo foi de $15,56 \%$ e para a variedade Reiko foi de $7,67 \%$, valendo a pena ressaltar que a variedade Reiko apresentou um teor de vitamina $C$ inicial $4,58 \%$ maior que a variedade Chandler. No que diz respeito as perdas individuais, por tratamento, foram semelhantes para as duas variedades (Figuras 23 e 24).

Com o aumento da temperatura, há uma transformação do ácido ascórbico em ácido dehidroascórbico e, segundo ESKIN (1991), correlações significativas foram encontradas entre cor e ácido ascórbico. Em estudos realizados por MAIN et al. (1986), descobriu-se que morangos fatiados possuem significativamente menos ácido ascórbico que morangos inteiros, provavelmente devido a exposição e oxidação.

De maneira geral, os teores de ácido ascórbico encontrados no presente trabalho são superiores aos observados por outros autores. SELVERAJ et al. (1976), estudando vinte variedades de morango, encontraram valores entre 29,2 e 89,1 mg; PASCHOALINO (1977), que constatou $46 \mathrm{mg} / 100 \mathrm{~g}$ e MAIN et al. (1986) encontraram valores variando de 23,9 a 41,2 mg/100 g. Os dados obtidos foram semelhantes aos observados por GHERARDI et al. (1983), que estudaram dezenove variedades de morangos verificando valores variando de 77,2 a 162,6 $\mathrm{mg} / \mathrm{kg}$ e BERBARI (1992) que verificou valores de 57,5 a $120 \mathrm{mg} / 100 \mathrm{~g}$ para a variedade Chandler e de 78,0 a $97,5 \mathrm{mg} / 100 \mathrm{~g}$ para a variedade Reiko.

\subsubsection{Análise sensorial}

D Na Tabela 15 são apresentados os resultados da avaliação subjetiva do sabor, cor e textura dos morangos termicamente processados.

No que diz respeito à textura, para a variedade Chandler o tratamento 6 diferiu significativamente do tratamento 1 e os demais tratamentos 


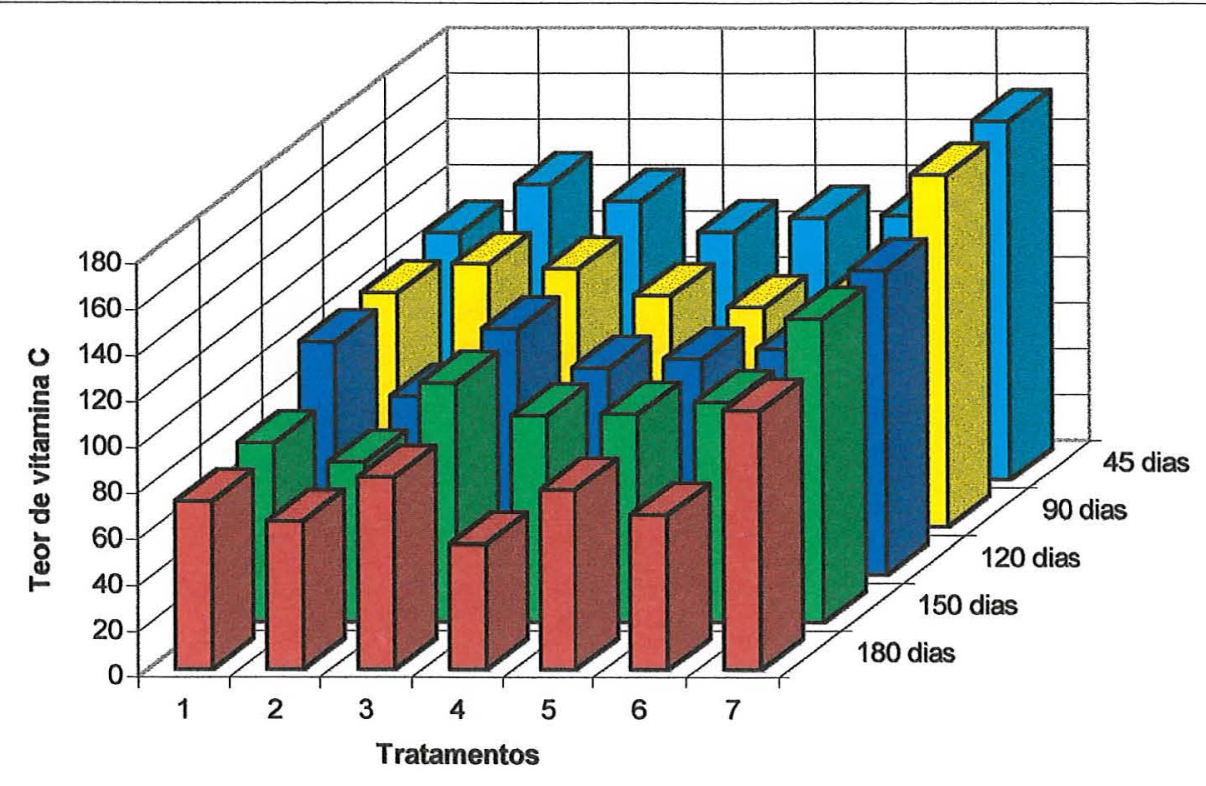

Figura 23. Variação dos teores de ácido ascórbico ( $\mathrm{mg} / 100 \mathrm{~g}$ de fruto) obtidos de acordo com os períodos de armazenamento - Variedade Chandler.

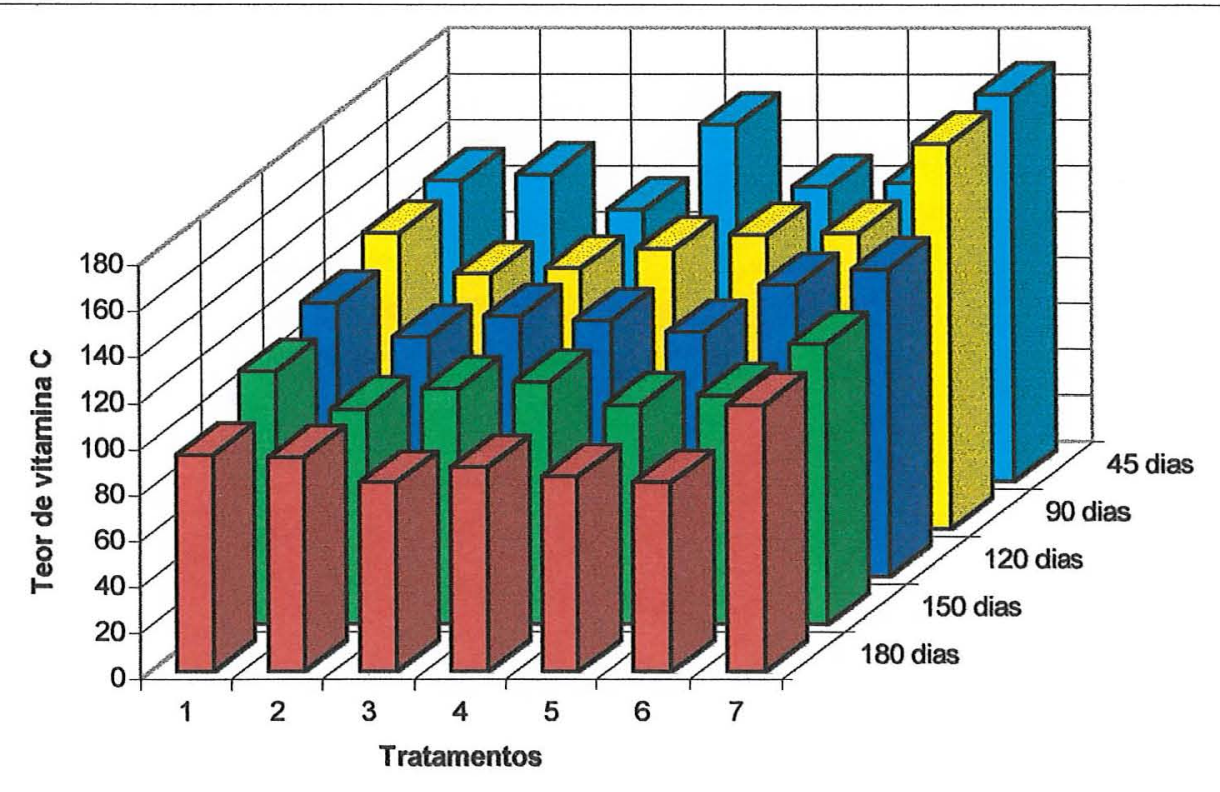

Figura 24. Variação dos teores de ácido ascórbico ( $\mathrm{mg} / 100 \mathrm{~g}$ de fruto) obtidos de acordo com os períodos de armazenamento - Variedade Reiko. 
não diferiram entre si; já, para a variedade Reiko, não houve diferença significativa entre os tratamentos. O tratamento 6 (morango + sacarose + pectina + cloreto de cálcio + corante) foi o que apresentou maior firmeza para ambas as variedades (Figura 25).

Com relação ao sabor, observa-se que, para a variedade Chandler não houve diferença significativa entre os tratamentos; já, para a variedade Reiko, o tratamento 6 diferiu significativamente do tratamento 1, porém, ambos não diferiram dos demais tratamentos (Figura 26).

Tabela 15. Avaliação sensorial dos morangos termicamente processados (shelf life $=60$ dias).

\begin{tabular}{|c|c|c|c|c|c|c|}
\hline Tratamentos & \multicolumn{2}{|c|}{ 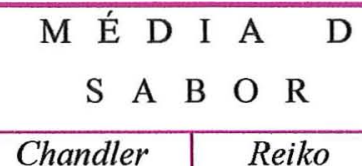 } & Chandler & Reiko & Chandler & Reiko \\
\hline 1 & $4,75^{\mathrm{A}}$ & $4,21^{\mathrm{B}}$ & $2,21^{\mathrm{D}}$ & $1,45^{\mathrm{E}}$ & $3,96^{\mathrm{B}}$ & $4,10^{\mathrm{A}}$ \\
\hline 2 & $4,80^{\mathrm{A}}$ & $5,07^{\mathrm{AB}}$ & $3,56^{\mathrm{CD}}$ & $2,37^{\mathrm{DE}}$ & $4,71^{\mathrm{AB}}$ & $4,20^{\mathrm{A}}$ \\
\hline 3 & $4,82^{\mathrm{A}}$ & $5,30^{\mathrm{AB}}$ & $3,68^{\mathrm{C}}$ & $2,81^{\mathrm{CDE}}$ & $4,30^{\mathrm{AB}}$ & $4,43^{A}$ \\
\hline 4 & $4,99^{\mathrm{A}}$ & $5,09^{\mathrm{AB}}$ & $2,60^{C D}$ & $4,08^{\mathrm{BC}}$ & $4,78^{\mathrm{AB}}$ & $4,58^{\mathrm{A}}$ \\
\hline 5 & $5,31^{\mathrm{A}}$ & $5,07^{\mathrm{AB}}$ & $8,59^{A}$ & $7,68^{A}$ & $4,09^{\mathrm{AB}}$ & $3,96^{\mathrm{A}}$ \\
\hline 6 & $4,66^{\mathrm{A}}$ & $5,38^{A}$ & $6,51^{\mathrm{B}}$ & $5,47^{\mathrm{B}}$ & $5,47^{\mathrm{A}}$ & $4,58^{\mathrm{A}}$ \\
\hline 7 & $5,04^{\mathrm{A}}$ & $4,96^{\mathrm{AB}}$ & $3,87^{\mathrm{C}}$ & $3,42^{C D}$ & $4,70^{\mathrm{AB}}$ & $3,60^{\mathrm{A}}$ \\
\hline F (trat.) & 0,41 n.s. & $1,98 \mathrm{n} \cdot \mathrm{s}$ & $47,04 * *$ & $5,55 * *$ & $2,36^{*}$ & 1,01 n.s. \\
\hline F(provad.) & $6,99 * *$ & $11,81 * *$ & $7,07 * *$ & $39,80 * *$ & $3,91 * *$ & $5,32 * *$ \\
\hline
\end{tabular}

n.s. - não significativo a nível de $5 \% *$ - significativo a nível de $5 \% \quad * *$ - significativo a nível de $1 \%$.

Médias na coluna seguidas de mesma letra não diferem entre si, pelo teste de Tukey, ao nível de $5 \%$ de probabilidade.

O "ratio", resultado da divisão graus Brix pela acidez total titulável, fornece uma idéia da acidez do fruto, isto é, um "ratio" baixo indica um fruto ácido, o que representa uma idéia de maturação do fruto, quanto mais alto o "ratio" mais avançado é o estado de maturação, influenciando, assim, diretamente o sabor dos frutos. De maneira geral, a variedade Reiko apresentou "ratios" 
menores que a variedade Chandler. A média geral para a variedade Chandler foi de 37,18 e para a Reiko de 34,67; porém, na matéria-prima notou-se o inverso, ou seja, a variedade Chandler possuia "ratio" menor que a variedade Reiko, 10,66 e 12,00, respectivamente. A alteração dos valores de "ratio" para o produto é em função da adição de sacarose.

Para a variedade Chandler o tratamento 5 foi o preferido pelos provadores, obtendo a maior nota para este atributo $(5,31)$, a qual corresponde a "sabor moderado" na escala utilizada, enquanto que, para a variedade Reiko, o preferido foi o tratamento $6(5,38)$. Conforme pode ser observado pela Tabela 15 , a variedade Reiko obteve maiores notas que a variedade Chandler neste atributo.

A adição de suco de amora na calda dos frutos (tratamento 5) causou uma estabilidade $e$ aumento na densidade da cor durante a estocagem. Quando se utilizou suco de morango, a cor permaneceu menos intensa do que quando se enriqueceu com suco de amora, estando de acordo com as observações de SKREDE et al. (1992). Segundo estes autores várias espécies de frutas contêm diferentes tipos de antocianinas que podem, até um certo ponto, influenciar a resistência à perda ou degradação da cor. A estabilidade da antocianina pode também ser influenciada por outros componentes da fruta, tais como o ácido ascórbico e compostos fenólicos. A razão da degradação da antocianina livre é duas vezes maior na calda de morangos, que possui uma proporção maior de pigmentos polimerizados; porém, a degradação da antocianina livre não tem impacto imediato na mudança da aparência visual de certos produtos. Quando a concentração de antocianinas no caldo de morango foi aumentada até níveis da calda de amora, a estabilidade dos pigmentos e da cor foi muito melhorada. A estabilidade na intensidade da cor vermelha é levemente melhor na calda fortificada de morango do que na calda de amora (SKREDE et al. 1992). 


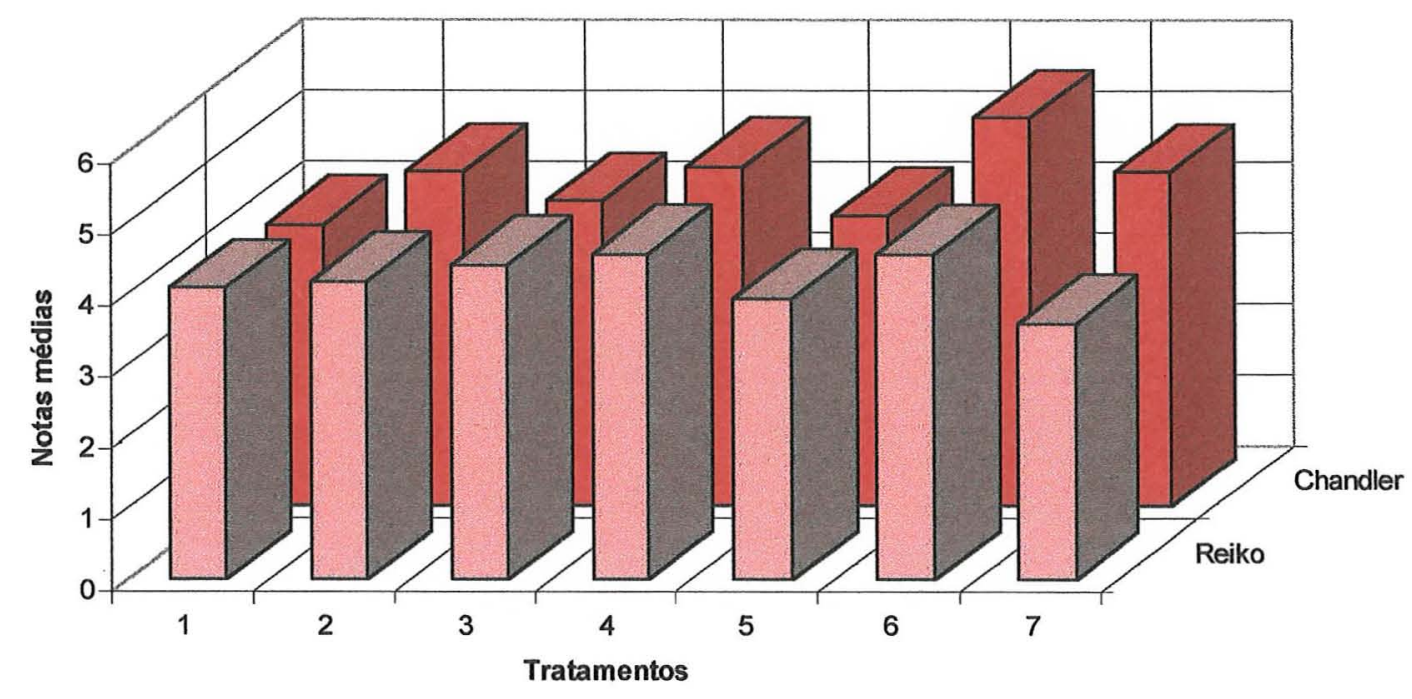

Figura 25. Valores médios obtidos na avaliação sensorial das amostras quanto ao atributo textura, segundo as variedades.

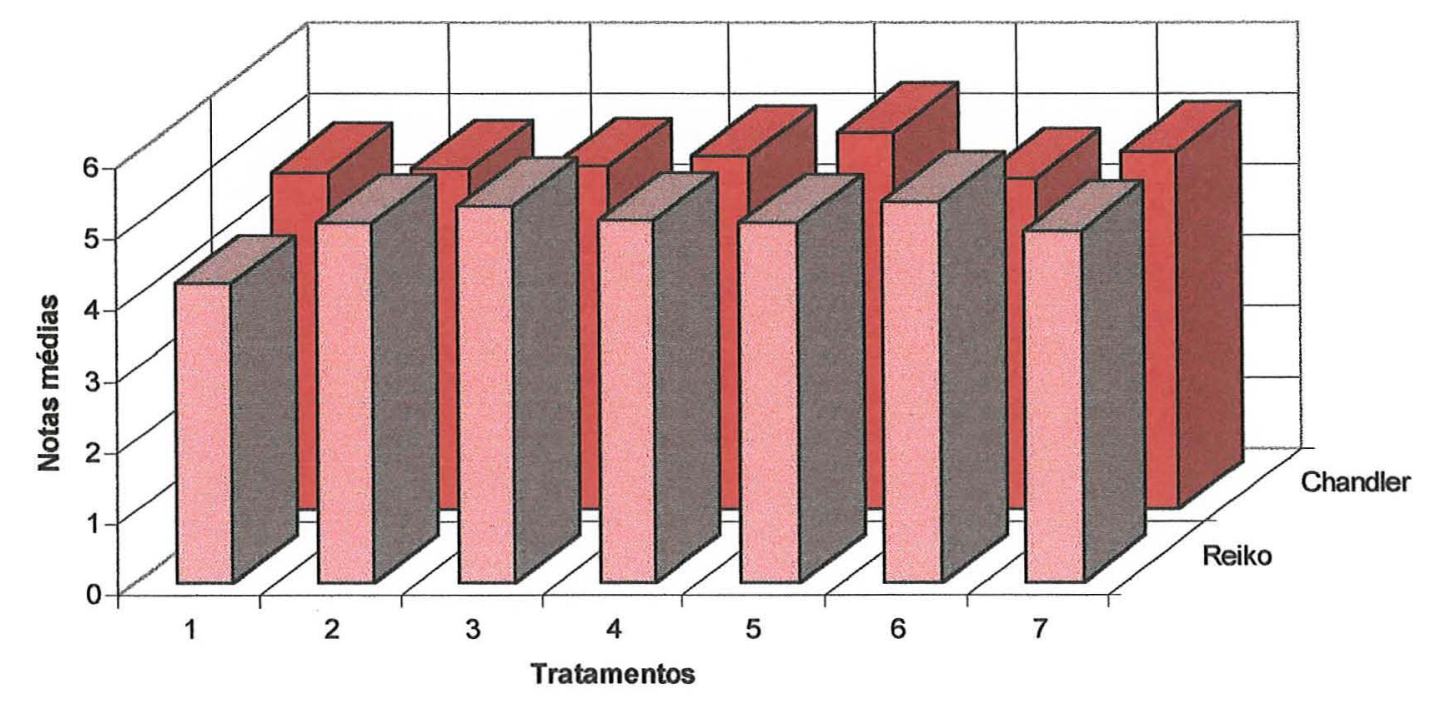

Figura 26. Valores médios obtidos na avaliação sensorial das amostras quanto ao atributo sabor, segundo as variedades. 
Segundo SKREDE et al. (1992), altas proporções antocianinas/ácido ascórbico favorecem a estabilidade da antocianina e da cor. A estabilidade do ácido ascórbico no suco de amoras tem sido atribuída a não ocorrência de oxidação enzimática, baixo conteúdo de cobre e alto conteúdo de citratos. Em estudos realizados por HUDSON et al. (1977), foi demonstrado que o ácido ascórbico não tem efeito na qualidade de morangos congelados.

A quantidade de ácido ascórbico é um fator importante na estabilidade da cor dos morangos, conforme pode ser observado pela Tabela 15 e Figura 27. Segundo BAKKER \& BRIDLE (1992) e BAKKER et al. (1992), condições que favorecem a oxidação do ácido ascórbico causam uma perda máxima de antocianinas; mas, quando o oxigênio é removido, não se percebe nenhuma deterioração de cor. Esta conclusão está de acordo com as observações feitas neste trabalho, onde verifica-se que, com a adição de ácido ascórbico, houve menor perda de pigmentos antociânicos, ou seja, com exceção dos tratamentos 5 e 6 , o tratamento 7 foi, de maneira geral, o que apresentou melhor valor médio na avaliação do atributo cor (Chandler $=3,87$ e Reiko $=3,42$ ). A ausência de oxigênio protegeu a degradação das antocianinas durante 0 armazenamento.

Os resultados da avaliação subjetiva da cor (Tabela 15 e Figura 27) para a variedade Chandler, mostraram que os tratamentos 5 e 6 diferiram entre si e dos tratamentos $1,2,3,4$ e 7 . O tratamento 5 obteve a maior nota para esse atributo $(8,59)$, a qual corresponde a "cor intensa" na escala utilizada; porém, como este tratamento teve a adição de suco de amora, estava descaracterizada a cor do morango, tendendo para a cor roxa. Para a variedade Reiko o tratamento 5 diferiu dos demais tratamentos, obtendo a maior nota $(7,68)$, a qual corresponde a "cor intensa" na escala utilizada; mas, como na variedade Chandler, houve descaracterização da cor. 0 tratamento 6 não diferiu do tratamento 4 , sendo que este último diferiu somente do tratamento 1 . 
Para ambas as variedades, o tratamento 6 foi considerado de "cor moderada" (médias das notas: 6,51 e 5,47, respectivamente, para as variedades Chandler e Reiko) pela equipe de provadores, sendo que a cor estava de acordo com a cor característica do morango, tanto em relação ao fruto como à calda.

De maneira geral, a variedade Chandler obteve notas maiores e menores variações estatísticas neste atributo quando comparada com a variedade Reiko. Os resultados da avaliação subjetiva da variedade Chandler mostraram que, quanto ao sabor, o melhor tratamento foi o $5 \mathrm{e}$, quanto à cor e à textura, o melhor tratamento foi o 6 . Já, para a variedade Reiko, de acordo com as médias obtidas para os atributos sabor, textura e cor (Tabela 15), verifica-se que o tratamento 6 foi o melhor.

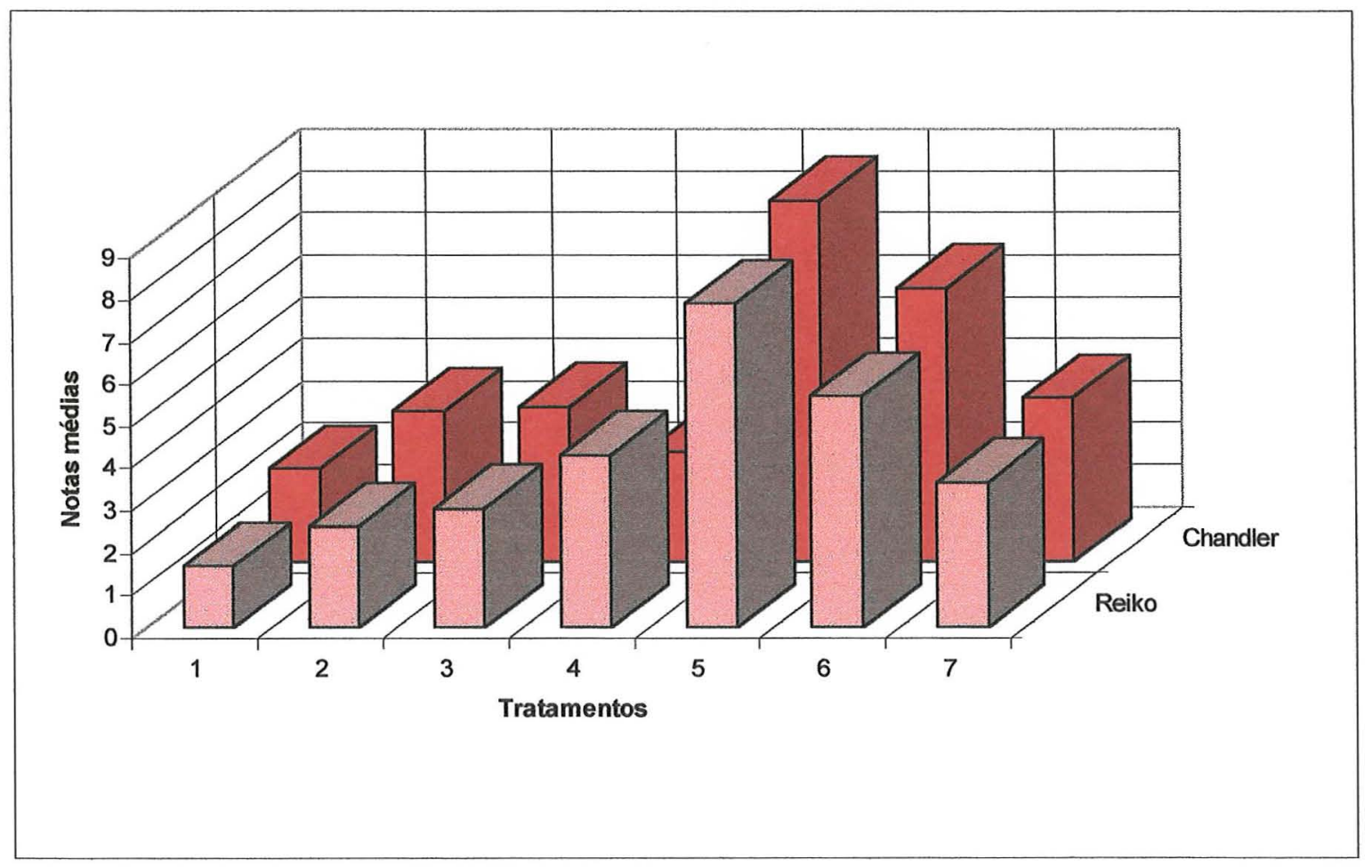

Figura 27. Valores médios obtidos na avaliação sensorial das amostras quanto ao atributo cor, segundo as variedades. 


\section{CONCLUSÕES}

Dentro das condições experimentais em que foi realizado este trabalho, pode-se chegar às seguintes conclusões:

- Sob o ponto de vista tecnológico, a matéria prima utilizada apresentou-se de excelente qualidade quanto às propriedades físicas (textura, porcentagem de rendimento e suculência) e químicas (teor de vitamina $\mathrm{C}$, graus Brix, valor de pH e acidez total titulável).

- No que diz respeito ao teor de vitamina $C$, como era esperado, 0 tratamento 7 (morango + sacarose + vitamina $\mathrm{C}+$ suco de morango) foi o que apresentou o maior teor, sugerindo também que altas concentrações de ácido ascórbico juntamente com o suco de morango favorece a estabilidade da antocianina $e$, conseqüentemente, da cor.

- As perdas de vitamina $C$ durante $o$ armazenamento aumentam à medida em que se aumenta o tempo de estocagem.

- A variedade Reiko apresentou teor de vitamina C mais elevado que a variedade Chandler. 
- Com base nos atributos sensoriais o tratamento 6 (morango + sacarose + pectina + cloreto de cálcio + corante) foi o que obteve melhores resultados, indicando que o uso de corante, cálcio e pectina seria uma opção viável para melhorar as características globais do produto.

- A variedade Chandler apresentou melhor textura e cor que a variedade Reiko.

- A variedade Reiko, de acordo com os resultados obtidos, é mais doce e possui melhor sabor que a variedade Chandler, porém, é mais clara.

- Em relação à textura dos frutos, a adição de pectina e cloreto de cálcio (tratamentos 3 e 6), foi notadamente efetiva na manutenção da firmeza dos frutos, os quais apresentaram valores de textura significativamente mais elevados que os dos demais tratamentos.

- Quanto à cor, os tratamentos que não continham suco de morango, suco de amora e corante foram mais susceptiveis à deterioração deste atributo, resultante dos efeitos combinados da degradação das antocianinas e a formação de pigmentos marrons.

- Foi observado que, com a adição de suco de amora (tratamento 5), a estabilidade da cor melhorou acentuadamente; porém, descaracterizou o produto, uma vez que a cor permaneceu, durante toda a estocagem, como no suco de amora (roxa). 
- Como era esperado, o tratamento térmico foi prejudicial para a cor e textura do produto.

- Foi observado que furando os frutos, estes apresentaram uma coloração mais uniforme em vez de serem mais claros no centro, conforme o normal.

- Os resultados obtidos neste trabalho sugerem que a Chandler é a melhor variedade e que o tratamento mais indicado para a obtenção de morango em calda é o tratamento 6 (morango + sacarose + pectina + cloreto de cálcio + corante); porém, permitem recomendar a realização de estudos mais detalhados e dirigidos para a melhor utilização de corantes e variações nas concentrações de suco de amora. 


\section{REFERÊNCIAS BIBLIOGRÁFICAS}

ADAMS, J.B.; ONGLEY, M.H. The degradation of anthocyanins in canned strawberries. Journal of Food Technology, v.8, n.3, p.305-307, 1973.

ALBREGTS, E.E.; HOWARD, C.M. Elemental composition of fresh strawberry fruit. Journal of the American Society for Horticultural Science, v.103, n.3, p.293 $-296,1978$.

ASEN, S.; NORRIS, K.H.; STEWART, A.N. Adsorption spectra and color of aluminum-cyanidin-3-glucoside complexes as influenced by $\mathrm{pH}$, Phytochem, v.8, p.653, 1969.

ASSOCIATION OF OFFICIAL ANALYTICAL CHEMISTS - Official methods of analysis. 12. ed. Washington, 1975. 1094p.

BAKKER, J.; BRIDLE, P. Strawberry juice colour: the effect of sulphur dioxide and EDTA on the stability of anthocyanins. Journal Science of Food Agriculture, v.60, p.477-481, 1992.

BAKKER, J.; BRIDLE, P.; KOOPMAN, A. Strawberry juice colour: the effect of some processing variables on the stability of anthocyanins. Journal Science of Food Agriculture, v.60, p.471-476, 1992.

BANZATTO, D.A.; KRONKA, S.N. Experimentação agrícola. 3 ed. Jaboticabal: FUNEP, 1995. 247p. 
BARNES, M.F.; PATCHETT, B.J. Cell wall degrading enzymes and the softening of senescent-strawberry fruit. Journal Food Science, v.41, n.6, p.1392-1395, 1976.

BERBARI, S.A.G. Avaliação da qualidade de algumas variedades de morango para o processo de congelação. Piracicaba, 1992. 90p. Tese (Mestrado) Escola Superior de Agricultura "Luiz de Queiroz" -, Universidade de São Paulo.

BLEINROTH, E.W.; HANSEN, H.; GARCIA, J.L.M. Técnica para manter a qualidade do morango nas temperaturas de 20 a $22^{\circ} \mathrm{C}$. Coletânea do Instituto de Tecnologia de Alimentos, v.9, p.125-140, 1978.

BOURNE, M.C. Effect of temperature on firmness of raw fruits and vegetables. Journal of Food Science, v.47, n.2, p.440-444, 1982.

CAMARGO, L.S. Novas variedades de morangueiro para o Estado de São Paulo. Piracicaba, 1960. 48p. Tese (Doutorado) - Escola Superior de Agricultura "Luiz de Queiroz", Universidade de São Paulo.

CARUSO, J.G.B.; CAMARGO, R.; Microbiologia de Alimentos. Generalidades. Alteração dos Alimentos. In: CAMARGO, R. de. Tecnologia dos produtos agropecuários. Alimentos. São Paulo: Nobel, 1984. p.35-49.

CASH, J.; SISTRUNK, W.A. Anthocyanin pigment concentration and type are important for color in strawberries. Arkansas Farm Research, v.19, n.3, p.8, May/June, 1970.

CATALÁ, R. Envases para alimentos. In. YÚFERA, E.P. Quimica Agrícola III Alimentos. Madrid: Alhambra, 1980. p.607-673. 
CEMEROGLU, B.; VELIOGLU,S.; ISIK, S. Degradation Kinetics of anthocyanins in sour cherry juice and concentrate. Journal of Food Science, v.59, n.6, p.1216-1233, 1994.

CHICHESTER, C.O. The Chemistry of plant pigments. New York: Academic Press, 1982. 218p.

DAWSON, E.H., Sensory testing guide for panel evaluation of food and beverages. Food Technology, v.16, n.8, p.25-31, 1964.

ESKIN, N.A.M. Quality and preservation of fruits. Boca Raton: CRC Press, 1991. p.196-205.

EVANGELISTA, J. Tecnologia de alimentos. Rio de Janeiro: Atheneu, 1987. $652 p$.

FERNANDES, M.H.C. Vida de prateleira de enlatados de origem vegetal. Boletim do Instituto de Tecnologia de Alimentos, v.19, n.3, p.227-52, jul./set.1982.

FIK, M.; MACURA, R. Changes of quality of frozen fruits kept in cold storage. Nutrition Abstracts and Reviews, v.21, n.8, p.13-15, 1986.

FONSECA, H.; NOGUEIRA, J.N. Processamento e conservação de alimentos de origem vegetal - frutas. In: CAMARGO, R. de. Tecnologia dos produtos agropecuários. Alimentos. São Paulo: Nobel, 1984. p.113-124.

FORNEY, C.F.; BREEN, P.J. Sugar content and uptake in the strawberry fruit. Journal of the American Society for Horticultural Science, v. 111, n.2, p.241-247, 1986.

FRANK, R.A.; DUCHENY, K.; MIZE, S.J.S. Strawberry odor, but not red color, enhances the sweetness of sucrose solutions. Chemical senses, v.14, n.3, 
p.371-377, 1989.

FUSTER, C.; PRESTANO, G.; CANET, W. Effect of pre-treatments and freezing of different strawberry varieties. Refrigeration Science and Technology. n.4, p.350-356, 1982.

GARROTE, R.L.; BERTONE, R. Evaluação química e adaptabilidade ao processo de congelamento de variedades de morangos. Indústria Alimentar, v.1, n.5, p.30-39, set./out. 1976 .

GAVA, A.J. Princípios de tecnologia de alimentos. São Paulo: Nobel, 1985. $264 p$.

GHERARDI, S.; BAZZARINI, R.; BIGLIARDI, D.; TRIFIRÒ, A. Caratteristiche analitiche di fragole di diversa provenienza. Industria Conserve, v. 58, n.2, p.101-104, 1983.

GIRARDOT, N.F.; PERYAM, D.R.; SHAPIRO, R., Selection of sensory testing panels. Food Technology, v.6, n.4, p.140-143, 1952.

GOMES, F.P., Curso de estatística experimental. 5.ed., São Paulo: Nobel, 1973a, 468p.

GOMES, R.P. Fruticultura brasileira. São Paulo: Nobel, p.342-348, 1973 b.

GUEGOV, Y.; KAROV, T.; KALINOV, V.; NIKOLOV, D. Freezing suitability of some strawberry varieties. In: Progress in the design and operation of refrigeration equipment and the processing of fruit and vegetables by refrigeration. Refrigeration Science and Technology, n.4, p.233-238, 1982.

HANCOCK, J.; LUBY, J.J. Genetic resources at our doorstep: the wild strawberries. Bioscience, v.43, n.3,p.141-146, March. 1993. 
HUBER, D.J. Strawberry fruit softening: the potential roles of polyronides and hemicelluloses. Journal of Food Science, v.49, n.5, p.1310-1315, 1984.

HUDSON, M.A.; HOLGATE, M.E.; GREGORY, M.E.; PICKFORD, E. Home frozen strawberries. II. Influence of additives in syrup on sensory assessments and texture measurements. Journal of Food Technology, v.10, n.6, p.689-698, 1975a.

HUDSON, M.A.; LEACH, M.; SHARPLES, V.J.; PICKFORD, E. Home frozen strawberries. I. Influences of freezing medium, fanning, syrup temperature, soaking time, storage time and temperature, and rates of frezzing and thawing on sensory assessments. Journal of Food Technology, v.10, n.6, p.681-688, $1975 b$.

HUDSON, M.A.; RICKETTS, V.A.; HOLGATE, M.E. Home frozen strawberries. III. Factors affecting sensory assessment. Journal of Food Technology, v.12, n.4, p.421-426, 1977.

HYAMS, E. Strawberry cultivation. London: Faber \& Faber Limited, 1955. 157 p.

JACKIX, M.H. Doces, geléias e frutas em calda. São Paulo: İcone, 1988. 172p.

KOLEV, D.; USHEVA, V.; POPOV, K.H. Use of synthetic colouring agents for canned strawberries. Nauchni Turdove, Nauchnoizsledovatelski Institut po Konserva Promishlenost, v.11, p.15-25, 1974.

LANCELLOTI, S. As magias do morango: belo, saboroso e com poderes medicinais. Alimentos e Tecnologia. v.2, n.14, p.15-16, 1987.

LEME JÚNIOR, J.; MALAVOLTA, E. Determinação fotométrica de ácido ascórbico. Anais da Escola Superior de Agricultura "Luiz de Queiroz", v.7, p.115-129, 1950. 
LIAO, H.; CAI, Y.; HASLAM, E. Polyphenol interactions. Anthocyanins: copigmentation and colour changes in red wines. Journal Science of Food Agriculture, v.59, p.299-305, 1992.

MAIN, G.L.; MORRIS, J.R.; WEHUNT, E.J. Effect of preprocessing treatments on the firmness and quality characteristics of whole and sliced strawberries after freezing and thermal processing. Journal of Food Science, v.51, n.2, p.391-394, 1986.

MARTIN, S.L., Selection and training of sensory judges. Food Technology, Chicago, v.27, n.11, p.22-26, 1973.

MARTIN, Z.J. Frutas em compotas. Boletim do Instituto de Tecnologia de Alimentos. Campinas. n.2, p.57-67, 1965.

MEDINA. J.C.; BLEINROTH, E.W.; BERNHARDT, L.W.; HASHIZUME, T.; RENESTE, O.V.; VIEIRA, L.F. Cajú - da cultura ao processamento e comercialização. Campinas: ITAL, 1978.

MORI, T.; SAKURAI, M.; SHIGETA, J.; YOSHIDA, K.; KONDO, T. Formation of anthocyanins from cells cultured from different parts of strawberry plants. Journal of Food Science, v.58, n.4, p.788-792, 1993.

MORRIS. J.R.; SISTRUNK, W.A.; SIMS, C.A.; MAIN, G.L.; WEHNT, E.J., Effects of cultivar, postharvest storage reprocessing dip treatments and style of pack on the processing quality of strawberries. Journal of the American Society for Horticultural Science, v.110, n.2, p.172-177, 1985.

NARUKAMA, N.; ISHIABASHI, K.; OGIWARA, S.; TOKI, T. The Pedigree and characteristics of new strawberry variety Reiko. Bulletin Chiba Agriculture Experimentation Station, n.22, p.45-55, 1981. 
NEAL, G.E. Changes occurring in the cell walls of strawberries during ripening. Journal Science of Food Agriculture, v.16, p.604-611, 1965.

PADOVANI, M.I. Morango. O delicado e saboroso fruto da integração dos povos. São Paulo: Ícone, 1991. 68p.

PASCHOALINO, J.E. Fatores que influem sobre a qualidade do morango congelado. Boletim do Instituto de Tecnologia de Alimentos, v.51, p.113$124,1977$.

PASCHOALINO, J.E. Congelamento de hortaliças. In: PASCHOALINO, J.E. Processamento de hortaliças. Campinas: ITAL, 1989. p: 48-49.

PASCHOALINO, J.E.; ZUCCHINI, A.G.; BERNHARDT, L.W.; SILVA, S.D. da; FERREIRA, V.L.P. Estudos sobre a avaliação de diferentes variedades locais de morango em relação à sua adequabilidade para congelamento. Coletânea do Instituto de Tecnologia de Alimentos, v.5, p.365-376, 1973/74.

PASCHOALINO, J.E. et al. Congelamento de frutas e hortaliças. In: TEIXEIRA NETO, R.O. coord. Curso de alimentos congelados. Campinas: ITAL, 1979. p.2-27.

ROMMEL, A.; WROLSTAD, R.E.; HEATHERBELL,D.A. Blackberry juice and wine: processing and storage effects on anthocyanin composition, color and appearance. Journal of Food Science, v.57, n.2, p.385-391, 1992.

SAWYER, F.M. Interaction of sensory panel and instrumental measurement. Food Technology, v.25, n.3, p.51-52, 1971.

SCHNEIDER, G.W.; SCARBOROUGH, C.C. Fruit growing. New York: Prentice Hall, p.275-288. 1960. 
SELVARAJ, Y. et al. Studies on chemical composition of twenty strawberry (Fragaria ananasa) varieties. Journal of Food Science and Technology, v.13, n.4, p.195-198, 1976.

SISTRUNK, W.A.; CAIN, R.F.; VAUGHAM, E.K.; LAGERSTELT, H.B. Factors contributing the breakdown of frozen sliced strawberries. Food Technology, v.14, p.640-644, 1960.

SISTRUNK, W.A.; MORRIS, J.R.; GASCOIGNE, H.L. Effects of storage temperature and treatments on quality changes in strawberry spread. Arkansas Farm Research, v.31, n.2, p.7, March/April. 1982.

SIMÃO, A.M. Corantes. In. Aditivos para alimentos sob o aspecto toxicológico. 2. ed. São Paulo: Nobel, 1989. cap. 3, p.37-55.

SKREDE, G. Changes in sucrose, fructose and glucose content of frozen strawberries with thawing. Journal of Food Science, v.48, n.4, p.1094-1096, 1983.

SKREDE, G.; WROLSTAD R.E.; LEA, P.; ENERSEN, G. Color stability of strawberry and blackcurrant syrups. Journal of Food Science, v.57, n.1, p.172-177, 1992.

SLAUGHTER, D.C.; O'BRIEN, M.; CHEN, P. Grading strawberries for processing. American Society of Agricultural Engineers. v.26, n.6, p.1866-18669, Nov./Dec. 1983.

SOLER, M.P.; RADOMILLE, L.R.; TOCCHINI, R. Processamento. In. Curso de conservas de frutas. Campinas: ITAL, 1982. p.1-80.

SONDHEIMER, E.; KERTESZ, Z.I., The anthocyanin of strawberries. Journal of American Chemistry Society, v.70, p.3476. 1948. 
SPAYD, S.E.; MORRIS, J.R. Immature fruits do not affect color stability of strawberry puree. Arkansas Farm Research, v.31, n.3, p.2, May/June. 1982.

SPAYD, S.E.; MORRIS, J.R. Influence of in immature fruits of strawberry jam quality and storage stability. Journal Food Science, v.46, n.2, p.414-418, 1981.

SPAYD, S.E.; MORRIS, J.R.; ROBERT, C.L. Influence of peroxidase and polyphenol oxidase on the color of puree from machine-harvested strawberries. Journal of the American Society for Horticultural Science, v.107, n.6, p.1070-1073, 1982.

STILLMAN, J.A. Color influences flavor identification in fruit-flavored beverages. Journal of Food Science, v.58, n.4, p.810-812, 1993.

SZCZESNIAK, A.S.; SMITH, B.J., Observations of strawberry texture a threepronged approach. Journal of Texture Studies, v.1, n.1, p.65-89, 1969.

TAKAHASHI, M.Y. Monografias de corantes naturais para fins alimentícios. Padrões de identidade e qualidade. 2. ed.. São Paulo: Sanrisil, 1987. cap.1., p.8-16

TOLEDO, M.C.F.; GUERCHON, M.S. Corantes artificiais em alimentos. Ciência e Tecnologia de Alimentos, v.10, n.1, p.120-136, jan./jun. 1990.

WESCHE-EBELING, P.; MONTGOMERY, M.W. Strawberry polyphenoloxidase: its role in anthocyanin degradation. Journal of Food Science, v.55, n.3, p.731-734, 1990.

WOODWARD, J.R, Physical and chemical changes in developing strawberry fruits. Journal Science of Food Agriculture, v.23, p.465, 1972. 
WROLSTAD, R.E.; SKREDE, G.; ENERSEN, G. Influence of sugar on anthocyanin pigment stability in frozen strawberries. Journal of Food Science, v.55, n.4, p.1064-1072, 1990. 